UNIVERSIDADE DE SÃO PAULO

FACULDADE DE FILOSOFIA, LETRAS E CIÊNCIAS HUMANAS

DEPARTAMENTO DE SOCIOLOGIA

PROGRAMA DE PÓS-GRADUAÇÃO EM SOCIOLOGIA

ADRIANA NAOMI LEITE

\title{
MILAGRE ACADÊMICO: A \\ institucionalização das ciências sociais brasileiras \\ (1964-1985)
}

VERSÃO CORRIGIDA

São Paulo

2015 
UNIVERSIDADE DE SÃO PAULO

FACULDADE DE FILOSOFIA, LETRAS E CIÊNCIAS HUMANAS

DEPARTAMENTO DE SOCIOLOGIA

PROGRAMA DE PÓS-GRADUAÇÃO EM SOCIOLOGIA

\section{MILAGRE ACADÊMICO: A}

\section{institucionalização das ciências sociais brasileiras \\ (1964-1985)}

Adriana Naomi Leite

Dissertação de mestrado a ser apresentada ao Programa de Pós-Graduação em Sociologia da Universidade de São Paulo, para a obtenção do título de mestre em sociologia.

Orientador: Luiz Carlos Jackson

VERSÃO CORRIGIDA

De acordo: HQPachoen

São Paulo 
Para Katia (in memorian) 


\section{Agradecimentos}

Existem muitas pessoas e instituições as quais devo prestar o meu agradecimento pelo amparo concedido durante essa pesquisa.

Em primeiro lugar, gostaria de agradecer à CAPES (Coordenação de Aperfeiçoamento de Pessoal de Nível Superior) pela bolsa de estudos concedida, viabilizando a realização dessa dissertação.

Do mesmo modo, agradeço o Departamento de Sociologia da Universidade de São Paulo e o seu pessoal técnico-administrativo pela atenção e paciência ao longo desse processo. Aproveito para agradecer também ao Centro de Apoio à Pesquisa Histórica (CAPH) pela ajuda no levantamento do material sobre o curso de ciências sociais durante os anos de 1964-1985.

Gostaria de expressar também a minha gratidão à banca do exame de qualificação formada pelos professores Sylvia Gemignani Garcia e Fabio Cardoso Keinert pelos comentários e sugestões apresentados, colaborando para o resultado final aqui apresentado. Em especial, agradeço à professora Sylvia pela experiência e conversa partilhada ao longo do semestre de estágio de supervisionado na disciplina "Elaboração de Projetos de Pesquisa em Sociologia", no qual os dilemas da pesquisa novamente entraram em cena e cujos conselhos foram de extrema valia para a realização desse trabalho.

Aos professores Eva Blay, Maria Helena, Heloísa Martins, Irene Cardoso e Sergio Miceli registro a minha gratidão pela colaboração durante as entrevistas realizadas que, no cruzamento entre memórias, impressões e reflexões sobre a sociologia, enriqueceram esse trabalho.

À Luiz Carlos Jackson agradeço a orientação e acolhida durante toda essa empreitada. Acompanhando de perto a realização dessa dissertação desde a elaboração do seu projeto, ele esteve presente em todas as etapas dessa investigação sempre com

sugestões e comentários pertinentes para a melhor condução da pesquisa. À ele sou grata por todos os apontamentos e também pela cumplicidade expressa nessa trajetória.

Aos colegas de curso, agradeço pela contribuição, cada qual a seu modo, no desenvolvimento desse trabalho. Ao Dimitri, Wellington, Pedro e Monica pela leitura 
atenciosa e comentário dos dois primeiros capítulos. À Juliana, Natália, Maysa, Anouch e Pedro pela vivência de todos os anseios, alegrias e ansiedades que cercam a conclusão de uma dissertação.

Agradeço também aos amigos de longa data: Paulo, Luiz, Bia, Paula, Ágata e Daniela. Crescendo juntos desde a infância, divido com vocês mais essa fase e agradeço a todo amparo carinhosamente concedido em todas as alegrias e tropeços da vida. À Fatima pela preocupação e abrigo em momentos de dificuldades.

Aos familiares agradeço em especial: O meu irmão, Erick, pelo apoio inestimável e cumplicidade com a qual temos enfrentado todas as tempestades e desarranjos de percurso. À Chris e Rodrigo pelo estímulo e carinho de sempre. À minha sobrinha, Nathália, manifesto o meu amor e gratidão por toda a alegria que trouxe à vida.

Ao Alesandro agradeço pelo apoio, dedicação e parceria com a qual buscamos reconstruir nossas jornadas. À ele expresso o amor mais sincero.

À minha mãe, Katia (in memorian), dedico esse trabalho como forma de expressar a gratidão pela influência decisiva que teve em minha vida. Com uma presença marcante e de uma generosidade sem tamanho, agradeço a ela por todas as experiências partilhadas e cuja lembrança é sempre viva e cheia de saudades. 


\section{RESUMO}

O trabalho que se segue buscará analisar o processo de institucionalização das ciências sociais brasileiras durante o período de 1964-1985. Entendendo essa fase como um momento de notável expansão desse campo de conhecimento no Brasil, a pesquisa analisará diferentes dimensões desse processo, atenta aos novos projetos acadêmicos empreendidos, às lideranças consolidadas, assim como aos debates de maior destaque promovidos durante o período. Analisando institutos de pesquisa, programas de pósgraduação, assim como a própria Universidade de São Paulo, a dissertação oferece um panorama dessa etapa do desenvolvimento das ciências sociais brasileiras.

Palavras-chave: Cientistas sociais brasileiros, institucionalização, história intelectual, antropologia, ciência política, Universidade de São Paulo. 


\begin{abstract}
The following research aims to analyze the process of institutionalization of the social sciences in Brazil during the period 1964-1985. Understanding this phase as a time of significant expansion of this field of knowledge in Brazil, the research will examine different dimensions of this process, attentive to new academic projects undertaken, consolidated leadership, as well as the most prominent debates promoted during the period. Analyzing research institutes, graduate programs, as well as his own University of São Paulo, the dissertation provides an overview of this stage of development of the Brazilian social sciences.
\end{abstract}

Keywords: Brazilian social scientists, institutionalization, intellectual history, anthropology, political science, University of São Paulo. 


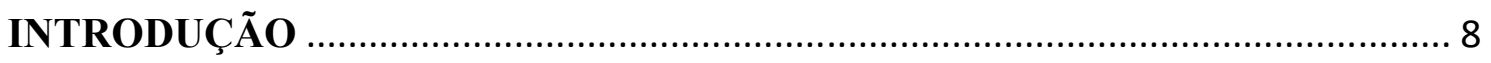

CAPÍTULO 1 - PROJETOS EM DISPUTA....................................................... 12

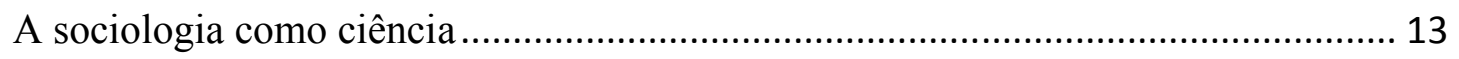

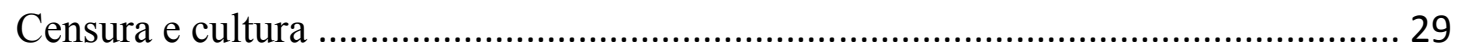

Ciência Política versus Sociologia......................................................................... 32

A antropologia nas ciências sociais ...................................................................... 36

O BIB e a especialização nas ciências sociais …………………………………..... 40

CAPÍTULO 2 - OS INSTITUTOS DE PESQUISA E AS REVISTAS NA

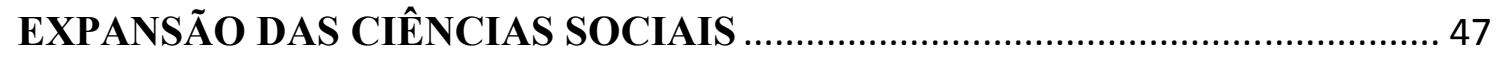

A expansão da antropologia e os seus periódicos: O caso da Revista de Antropologia

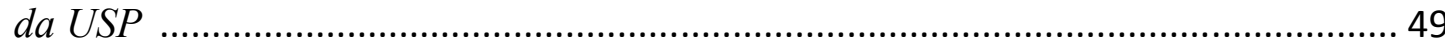

A autonomia do político em debate: Os institutos de pesquisa e as revistas

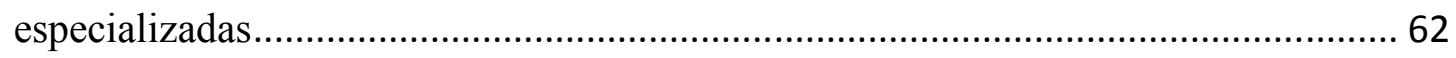

Cebrap, Iuperj e DCP - UFMG postos em perspectiva.............................................. 82

CAPÍTULO 3 - ENTREATO: A SOCIOLOGIA DA USP E A DITADURA

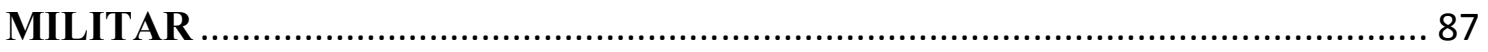

A Reforma Universitária e a sua implementação na Universidade de São Paulo ...... 89

A pós-graduação da sociologia na USP .................................................................... 97

A sociologia uspiana no quadro de expansão nacional das ciências sociais ............. 112

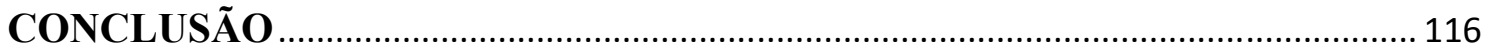

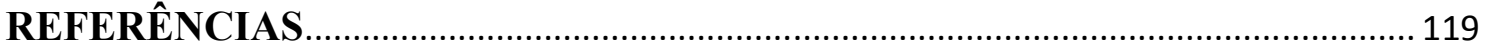




\section{INTRODUÇÃO}

O trabalho que se segue tem como objetivo principal compreender o desenvolvimento das ciências sociais no Brasil entre 1964 e 1985, atentando-se para as profundas transformações que marcaram esse período. Esse esforço de reconstrução buscará problematizar diferentes dimensões desse processo, da reorganização institucional à formação de diferentes grupos e lideranças, esboçando um panorama do desenvolvimento desse campo de investigações no país.

Embora existam numerosos trabalhos sobre a institucionalização das ciências sociais no Brasil, a maioria deles é centrado na sua fase de "fundação" (1930-1964) ${ }^{1}$, enquanto os estudos sobre o período 1964-1985 ainda são raros e bastante recentes ${ }^{2}$. Por isso, longe de pretender esgotar o assunto, o trabalho apresentado se soma a esse conjunto de interpretações, adensando o conhecimento produzido acerca desse longo processo de autonomização das ciências sociais no Brasil.

A atuação da ditadura militar em relação às ciências sociais foi contraditória, combinando o afastamento de algumas das principais lideranças das universidades e o investimento no ensino superior e na pesquisa do país, o que garantiu a expansão dessas disciplinas, nacionalizando um campo de investigação que tinha expressão apenas no eixo Rio de Janeiro/São Paulo. O aspecto sui generis desse "milagre acadêmico" caracteriza a fase de 1964-1985 como o momento em que as ciências sociais se institucionalizaram nacionalmente, apesar dos impasses inerentes a esse movimento.

Trata-se de um período complexo na história brasileira, no qual o governo militar esteve na dianteira da condução de uma fase de desenvolvimento econômico e industrialização no país. Nesse contexto, a vida científica (entendida como dimensão crucial desse processo) vivenciou um momento de expansão e consolidação institucional, no qual as ciências sociais foram amplamente beneficiadas. Assim, o regime militar patrocinou a ampliação do número de vagas no ensino superior em todo

\footnotetext{
1 Entre muitos, podemos citar: Maria Arminda do Nascimento Arruda (1989, 1995); Sérgio Miceli (1989b, 1995, 2001); Heloísa Pontes (1998); Fernanda Peixoto (1989, 2000); Sylvia Garcia (2001); Irene Cardoso (1982); Maria Hermínia (1989); Luiz Carlos Jackson (2004); Mariza Corrêa (1995); Lucia Lippi de Oliveira (1995); Fernando Limongi (1995); e Carolina Pulici (2004).

${ }^{2}$ Destacam-se especialmente os estudos de Fabio Cardoso Keinert (2011); Mariza Corrêa (1995); Sérgio Miceli (1995) e Christina Rubim (1996).
} 
o país, aprovando a reforma universitária que, além de nacionalizar e regulamentar a pós-graduação no país, reorganizou todo o ensino e a pesquisa científica produzida no Brasil.

Em um contexto internacional de combate à "ameaça comunista", institutos como a Fundação Ford passaram a financiar importantes empreendimentos de pesquisa em países periféricos, como o Brasil. Foram criados nesse período programas de pósgraduação e institutos de pesquisas independentes das universidades que, dispondo de um montante considerável de recursos, puderam financiar as suas atividades, assim como a formação acadêmica de numerosos pesquisadores através das bolsas de estudo para o exterior. Áreas como a ciência política e a antropologia lideraram esse processo, em função da criação do Iuperj (Instituto Universitário de Pesquisas do Estado do Rio de Janeiro), do Cebrap (Centro Brasileiro de Análise e Planejamento), do Programa de Pós-Graduação do Departamento de Ciência Política da UFMG (DCP-UFMG) e do Programa de Pós-Graduação em Antropologia Social do Museu Nacional (PPGAS $\mathrm{MN}$ ). Esse novo modelo de organização rivalizou com a - até então dominante sociologia praticada na Universidade de São Paulo, gerando disputas, não apenas entre grupos concorrentes, mas também entre praticantes de disciplinas em busca de legitimação.

Sem perder de vista as correlações existentes entre as dinâmicas específicas da vida intelectual e o contexto político e social no qual essas iniciativas se inscreveram, o trabalho que se segue visa explorar essa nova fase das ciências sociais brasileiras, atentando-se às novas configurações institucionais instauradas, às lideranças que foram surgindo, assim como as disputas e debates que definiram os marcos gerais desse período.

Nesta empreitada foram mobilizadas diferentes estratégias e materiais de análise com o intuito de mapear as diferentes perspectivas e projetos concorrentes. Analisei artigos acadêmicos, revistas especializadas, dissertações e teses, além de entrevistas (algumas realizadas por mim entre 2013 e 2014). Para a análise desse material, minha interpretação se fez de modo a "a comprender um haz de textos como un todo o como un conjunto de relaciones y no como una suma de enunciados individuales" (Ringer, 2004, p.104).

O primeiro capítulo recupera o contexto de fundação dessas disciplinas - que data do início da década de trinta com a criação dos primeiros cursos de graduação nas 
universidades paulista e carioca - avançando até a sua fase de expansão no pós-1964, com a multiplicação dos institutos de pesquisa e programas de pós-graduação. $\mathrm{O}$ objetivo dessa reconstrução é apontar para algumas das mudanças mais decisivas no processo de institucionalização das ciências sociais brasileiras. Buscando sintetizar esse amplo processo, a análise tomou como fonte central de investigação um tipo de material específico: os "balanços disciplinares"3.

Trata-se de aqui de um tipo específico de texto cujo rendimento se encontra no fato de neles ser possível reconhecer as distintas concepções acerca do que deveriam ser as disciplinas, de como atuar profissionalmente, trazendo à tona as problemáticas envolvidas na consolidação e autonomização desse campo de conhecimento no país. Possibilitando ter acesso às principais dinâmicas envolvidas nesse processo, os "balanços disciplinares" se configuraram como uma via de acesso privilegiada em torno da qual esse capítulo introdutório foi organizado.

O segundo capítulo é dedicado ao aprofundamento do estudo sobre as ciências sociais durante o período de 1964-1985, detendo-se em um dos experimentos de maior destaque dessa fase: os institutos de pesquisa e os programas de pós-graduação. Colocando-se no centro das grandes inovações e disputas dentro desse campo, esses espaços foram se afirmando, reivindicando a ciência política e antropologia como disciplinas independentes e científicas. Preconizando um ideal de profissionalização e especialização, seus praticantes desafiaram a posição dominante anteriormente detida pela sociologia. Buscando explorar esse processo, o presente capítulo se valeu da análise das revistas especializadas publicadas por esses institutos, visando apreender todo esse novo conjunto de problemas e atores que ganharam expressão nesse campo em expansão.

Assim, elegeu-se a análise das revistas Dados, Estudos Cebrap e Cadernos do $D C P$, do Iuperj, do Cebrap e do DCP da UFMG, respectivamente, todas elas centradas na área de ciência política, além da Revista de Antropologia da USP como representante da área de antropologia. Tomando como empréstimo o comentário de Sergio Miceli acerca desse tipo de publicação, os periódicos científicos evidenciam "o estado das Ciências Sociais na época, veiculando hipóteses, teses, resultados, explicações, fontes e

\footnotetext{
${ }^{3}$ Os balanços disciplinares podem ser entendidos como um conjunto de textos nos quais se avalia - desde um ponto de vista ora mais descritivo, ora mais explicativo - o desenvolvimento de uma disciplina, de um conjunto de disciplinas ou mesmo de uma especialidade ao longo de determinado período de tempo.
} 
evidências de toda ordem, mas também dando vazão aos projetos, anseios e virtualidades" (MICELI, 1989a, p. 8). Com essa perspectiva em mente, esse material foi analisado ambicionando explorar o novo desenho institucional formado, delineando os seus personagens, perspectivas em concorrência e estratégias de legitimação.

Por fim, o terceiro capítulo examina o período 1964-1985 com os olhares voltados para a sociologia produzida na Universidade de São Paulo. Diretamente afetada pelo afastamento de suas lideranças da faculdade e em meio à conturbada execução da reforma universitária nessa instituição, a sociologia uspiana encontrou grandes dificuldades para manter-se à frente da produção intelectual na área. Soma-se a isso o destaque adquirido pelos institutos de pesquisa no cenário institucional, pondo em questão a universidade como locus da pesquisa científica. Nesse contexto adverso, buscaremos investigar como os sociólogos uspianos reorganizaram as suas atividades, compondo um quadro mais amplo desse período na história das ciências sociais brasileiras.

O capítulo acompanha o processo de implementação da reforma universitária nessa instituição que remodelou toda a estrutura de institutos e faculdades da USP, regulamentando sob novos moldes a graduação e pós-graduação, ao mesmo tempo em que extinguiu as cátedras dentro dos cursos, implementando em seu lugar o regime departamental. Como será explorado adiante, essas alterações tiveram impacto direto nas ciências sociais já debilitadas com a saída de diversos professores. 


\section{CAPÍTULO 1 - PROJETOS EM DISPUTA: A INSTITUCIONALIZAÇÃO DAS CIÊNCIAS SOCIAIS BRASILEIRAS}

Toda a instituição tem sempre o mínimo de continuidade, mas eu penso que o mais importante nos paralelos é sempre a descontinuidade manifesta. (FERNANDES, 1981-1984, p. 75).

Pretendo discutir neste capítulo os contornos gerais dos movimentos iniciais de institucionalização das ciências sociais no Brasil, comparando as fases de fundação (1930-1964) e expansão (1964-1985). O objetivo aqui é reconstituir, ainda que sumariamente, esse processo, atentando-se para os diferentes personagens e projetos em disputa. Buscando sintetizar esse amplo movimento a análise que se segue concentrarse-á em um tipo de material específico: os "balanços” disciplinares.

Como bem notou Maria Isaura Pereira de Queiroz, esse gênero de texto foi bastante recorrente nas ciências sociais brasileiras, acompanhando pari passu os processos de fundação e expansão dessas disciplinas desde a década de 1940 (QUEIROZ, 1972, p.511). É justamente a variedade e a regularidade encontrada de "balanços" disciplinares que torna possível a escolha dessa fonte para fundamentar uma reconstrução sintética da história das ciências sociais no Brasil. A partir da análise dos balanços disciplinares, é possível flagrar as distintas concepções sobre as disciplinas e mapear os projetos acadêmicos e intelectuais do período, assim como as tensões e disputas inerentes a esse processo.

A reconstituição do processo de institucionalização das ciências sociais no Brasil por meio da análise dos balanços disciplinares se apresenta, então, como um atalho, justamente porque permite, a partir de um conjunto delimitado de textos, acessar às dinâmicas centrais envolvidas na consolidação e autonomização desse campo de conhecimento no país. Os balanços se constituem como uma via de acesso privilegiada a partir da qual é possível entender o amplo contexto do desenvolvimento das ciências sociais no Brasil.

Esquematicamente, é possível diferenciar três tipos de balanços. Os do primeiro tipo foram produzidos principalmente na fase de "fundação", no qual se voltaram principalmente para o surgimento da sociologia no Brasil, debatendo as possibilidades, 
problemáticas e projetos para essa disciplina. Como representantes desse primeiro grupo, discutirei inicialmente textos publicados por Florestan Fernandes (1977), Antonio Candido ([1959] 2006) e Oracy Nogueira (1955) em São Paulo, além dos trabalhos publicados por Guerreiro Ramos (1957) e Costa Pinto no Rio de Janeiro.

O segundo tipo de balanço teria como referência a transição entre os períodos de “fundação" e "expansão", momento em que a antropologia e a ciência política buscaram legitimar-se no quadro mais amplo das Ciências Sociais. Os grandes adversários dos praticantes dessas disciplinas foram os sociólogos paulistas, que se destacaram no período anterior. Para tal, serão analisados os trabalhos publicados por Wanderley Guilherme dos Santos (1978), Bolívar Lamounier (1977), Roberto Cardoso de Oliveira (1988), Julio Mellati (1984) e Gilberto Velho (1980) ${ }^{4}$.

Por fim, o terceiro tipo de balanço seria aquele produzido já por especialistas dentro dessas disciplinas e encontrados primordialmente no Boletim Informativo Bibliográfico (BIB) criado em 1977; aqui a legitimação e reconhecimento de uma disciplina cedem lugar às especialidades dentro de um cenário de maior autonomização e consolidação deste campo científico no país.

\section{A sociologia como ciência}

Quando se trata de analisar o processo de fundação das ciências sociais no país, a figura de Florestan Fernandes aparece como um personagem central. Ingressando na então recém-criada graduação de ciências sociais da FFCL-USP no fim da década de 1930, o jovem intelectual publicou seus primeiros trabalhos sobre o folclore ${ }^{5}$ brasileiro ainda durante a graduação, cumprindo com sucesso, todas as etapas da titulação acadêmica e alcançando o seu posto mais elevado na década de 1950 ao assumir a Cadeira de Sociologia I em substituição a Roger Bastide. Ao longo dessa década, Florestan foi se consolidando como uma importante liderança nas ciências sociais paulistas, estando à frente da chamada "escola paulista de sociologia" formada com alguns de seus principais alunos ${ }^{6}$. A constituição da sociologia como uma ciência se

\footnotetext{
${ }^{4}$ Como é possível notar, a grande parte dos balanços disciplinares foi elaborada por homens, o que aponta para o protagonismo desse gênero e a dominação masculina vigente nesse campo.

5 Sobre os estudos sobre folclore produzidos por Florestan Fernandes, ver GARCIA, 2001.

${ }^{6}$ Sobre a "escola paulista de sociologia", ver ARRUDA, 1995.
} 
tornou uma das suas principais frentes de batalha a partir da qual se desenvolveram grande parte das suas disputas nas ciências sociais em formação (GARCIA, 2002, p. 109).

Os "balanços disciplinares" escritos por Florestan sobre o desenvolvimento da sociologia no Brasil expressaram exatamente esse momento da sua carreira, no qual a hegemonia do campo em gestação esteve em disputa e a formulação de um programa para sociologia no país se apresentou como um requisito fundamental. "Ciência e sociedade na evolução do Brasil", "Desenvolvimento histórico-social da sociologia no Brasil" e "O padrão de trabalho científico dos sociólogos no Brasil" 7 , foram três artigos escritos por Florestan na década de cinquenta, pouco depois de ele assumir a Cadeira de Sociologia I na USP e indicam de maneira bem concisa a sua posição nesse debate, servindo de base para a discussão que se segue.

Avaliando a evolução do pensamento social brasileiro, o autor concluiu que foi apenas com o desenvolvimento dos grandes núcleos urbanos como São Paulo que o pensamento científico racional ganhou espaço para se desenvolver (FERNANDES, 1977, p.22). De fato, a cidade de São Paulo passava por importantes transformações econômicas, sociais e culturais. Com uma inédita intensificação da industrialização e urbanização nas décadas de 1920 e 1930, estribada na exportação do café, e o impacto da imigração massiva, a cidade paulista vivenciou um momento de profundo dinamismo social. No campo da cultura é possível identificar essa efervescência com o surgimento do modernismo e a produção contínua de inovações e experimentos culturais, até então inéditos no país (ARRUDA, 2001, p.44).

Para Florestan, essa nova atmosfera social teria permitido ao pensamento racional adquirir uma posição dominante, tendo em vista as novas necessidades, técnicas e especialidades que esta nova estrutura social demandaria (FERNANDES, 1977, p.23). Nesse contexto de rápida transformação social, as ciências sociais ganhariam espaço com a criação dos seus primeiros cursos de graduação no país: A Escola Livre de Sociologia e Política (ELSP) em 1933, a Universidade de São Paulo (USP) em 1934 e a Universidade do Distrito Federal (UDF) em 1935.

No que diz respeito especificamente ao caso paulista, cabe destacar ainda a

\footnotetext{
${ }^{7}$ Publicados originalmente em 1956, 1956 e 1958, respectivamente. Posteriormente reunidos no livro "A etnologia e a sociologia no Brasil", São Paulo, Anhembi, 1958; e no livro “A sociologia no Brasil”, São Paulo, Editora Vozes, 1977. Utilizei como referência esta última publicação ao longo do texto.
} 
profunda associação entre o desenvolvimento institucional das ciências sociais na década de 1930 e as demandas dos grupos políticos e empresariais atuantes no mercado cultural (MICELI, 1989b, p.75). Em São Paulo, com a modernização da cidade, a elite dominante começou aos poucos se diferenciar. Além dos setores tradicionais, vinculados às grandes propriedades rurais e ao mercado de exportação, emergiu também uma nova fração de empreendedores capitalistas, entre os quais estavam aqueles que se dedicavam às atividades culturais - como jornais, editoras, empreendimentos educacionais -; destacando-se, em particular, o grupo Mesquita que editava $O$ Estado de São Paulo (MICELI, 2001, p.91).

Essas transformações foram logo recolocadas para o plano da política. Tais grupos e dissidentes da elite tradicional fundaram o Partido Democrático (PD) em 1926, em oposição ao hegemônico Partido Republicano Paulista (PRP). Os dois partidos continuaram em disputa na capital paulista até a Revolução de 1930 e o desalojamento de ambos os grupos do poder político nacional. Diante dessa nova conjuntura, esses setores se reaproximaram com o objetivo de recuperar o poder político perdido (Idem, $\mathrm{p}$. 101), formando a Frente Única em defesa da autonomia e constitucionalização. Isolados, no entanto, nesse empreendimento, os paulistas não conseguiram angariar apoio nos outros estados, sofrendo uma nova derrota em 1932.

Mesmo com a derrota militar, o governo Vargas continuava preocupado com uma possível oposição de São Paulo, contrária a sua permanência no poder. Assim, Armando Salles de Oliveira foi nomeado interventor de São Paulo em 1933, em função de suas boas relações com a elite dirigente paulista. A partir de então, o projeto de criação das universidades ganhou força e se concretizou logo depois da posse do interventor, sendo criadas em 1933 e 1934 a ELSP e a USP, respectivamente. A missão dessas instituições era clara: através do conhecimento e da elevação do nível cultural da sociedade, formar para a administração dos negócios públicos "elites poderosas" de cidadãos eminentes, que possam superar os vícios na gestão do aparelho estatal (CARDOSO, 1982, p.37). A criação das universidades surgiu, portanto, como parte de um projeto dessas elites: elas respondem ao seu ensejo de superar a sua marginalidade política através da formação de técnicos profissionais (ELSP) e de lideranças capazes de se colocar à frente da economia e da política do Estado e da Nação (USP).

Para Florestan, a institucionalização das ciências sociais nas universidades representava um elemento fundamental para o seu desenvolvimento. Para o autor, a 
integração da sociologia no ramo de saber positivo e no sistema institucional de ensino e pesquisa teria permitido a essa disciplina um novo impulso para o seu desenvolvimento em direção a uma técnica racional de consciência e explicação das condições de existência e do curso dos eventos históricos e sociais (FERNANDES, 1977, p.44). É, portanto, a partir dos elos construídos entre a modernização social, a institucionalização acadêmica e a ciência que o jovem intelectual construiu o seu arcabouço de análise do processo de desenvolvimento da sociologia no país, entendendo a criação dos cursos no ensino superior como momento fundamental para $\mathrm{o}$ desenvolvimento da sociologia no Brasil.

Essa valorização da institucionalização universitária na consolidação das ciências sociais brasileiras se relacionou bastante com a experiência paulista, na qual as universidades, apesar de terem sido encampadas pelas elites locais, se distanciaram progressivamente das intenções iniciais dos seus mentores, o que acabou favorecendo o desenvolvimento da sociologia como ciência (MICELI, 1989b, p. 86). A contratação de professores estrangeiros - sobretudo franceses e norte-americanos - para compor o quadro docente dessas instituições desempenhou um papel fundamental para essa reorientação ${ }^{8}$. Isto, porque foram esses estrangeiros (treinados nas regras e costumes da competição acadêmica europeia) que acabaram modelando o padrão de trabalho, a estrutura e orientação dos cursos nas universidades paulistas, assim como a hierarquia acadêmica estabelecida nas faculdades, fazendo com que essas instituições logo caminhassem em direção à constituição de uma cultura propriamente acadêmica, afastando-se, assim, daquele projeto para a universidade anteriormente concebido (Idem, p.81).

Em seu balanço sobre as ciências sociais, Fernando de Azevedo ratificou esse posicionamento, entendendo a criação das universidades paulistas como momento chave na fundação da sociologia e atribuindo a vinda dos professores estrangeiros como elemento imprescindível para o desenvolvimento do ensino, da pesquisa e da formação dos cientistas sociais brasileiros (AZEVEDO, 1956, p.387).

\footnotetext{
${ }^{8}$ No que diz respeito à USP, foi o intelectual francês Georges Dumas que, dispondo de uma relação de constante intercâmbio com a ala cultural da elite paulista, acabou se responsabilizando pela escolha dos professores franceses que vieram para esta universidade. No que tange aos professores norte-americanos que vieram lecionar na ELSP, é importante sublinhar a importância de Donald Pierson nesse processo. Formado pelo Departamento de Sociologia e Antropologia da Universidade de Chicago, o sociólogo esteve à frente da organização do curso de ciências sociais e da pesquisa impulsionada a partir desta. Para uma análise mais detalhada das relações entre as missões estrangeiras e as instituições de ensino superior paulistas, ver MASSI, 1989.
} 
Como veremos adiante, esse critério de avaliação das ciências sociais, cunhado no seu processo de institucionalização nas universidades, seria bastante criticado, a partir do Rio de Janeiro, por Wanderley Guilherme dos Santos, figura de proa da nascente ciência política brasileira. No entanto, até 1964, o entendimento da instituição universitária como um divisor de águas na história das ciências sociais brasileiras foi dominante entre os seus praticantes e a figura de Florestan Fernandes encarnou como ninguém essa perspectiva. Não por acaso todos os balanços publicados posteriormente dialogaram - seja enaltecendo, seja divergindo - com essa perspectiva.

Um exemplo representativo nessa direção foi o escrito pelo próprio Antonio Candido. Isso, porque dentro da FFLC-USP, esses sociólogos incorporaram estilos acadêmicos muito diferentes a partir dos quais se desenvolveram distintas concepções e práticas sociológicas em disputa pela definição da natureza legítima da perspectiva de conhecimento dos fenômenos sociais e culturais (GARCIA, 2002, p. 145). Trata-se de personagens centrais na demarcação de disposições intelectuais-acadêmicas, materializadas nas Cadeiras de Sociologia I e Sociologia II. Como lembrou Fernando Henrique, comparando esses dois autores: "O Florestan marcava, porque o Florestan era realmente a Universidade como, vamos dizer, força total, era guerra total. (...) $\mathrm{O}$ Antonio Candido (...) marcava (...) como alguma coisa assim, de a gente transcender o cotidiano para se fazer parte do mundo da cultura" (CARDOSO, 1981, p. 159).

Tais estilos podem ser apreendidos nos balanços disciplinares que escreveram. Em seu artigo publicado em $1957^{9}$, Antonio Candido optou, ao refletir sobre o processo de consolidação da sociologia no Brasil, por reforçar as linhas de continuidade entre a disciplina que surgia e a tradição anterior do pensamento brasileiro. Em seu artigo sobre o desenvolvimento da sociologia no Brasil, o autor começou valorizando a produção ensaística, sugerindo, entretanto, que um novo espírito emergiria com a institucionalização acadêmica da sociologia. Sendo condição e consequência do desenvolvimento dessa disciplina, tal espírito consistiria na superação da mentalidade literária que impregnava os estudos sociais no país (CANDIDO, 2006, p.291). Esse processo teria implicado, por sua vez, a valorização de estudos objetivos e rigorosos da matéria social, cada vez mais afastados das preocupações estéticas e literárias. O espírito literário cederia lugar ao espírito científico na investigação da sociedade

\footnotetext{
${ }^{9}$ O artigo A sociologia no Brasil foi publicado em 1957 na Enciclopédia Delta-Larrouse e escrito a pedido de Fernando de Azevedo (para esse capítulo, foi utilizada a versão desse artigo publicada na Revista Tempo Social, nº18, v.1, São Paulo, 2006).
} 
brasileira, evidenciando uma delimitação mais clara entre as ciências humanas; o que, para o crítico, constituiria um alto índice de maturidade cultural (Idem, p. 292).

No entanto, ao longo desse processo de formação de um espírito científico, Antonio Candido não deixa de valorizar o que chamou de "sincretismo" na sociologia brasileira, isto é, certa flexibilidade nas suas atividades que a permitiria se estender sobre outros setores que lhe estariam vedados pela especialização acadêmica excessiva. Assim, o intelectual clamava pela criatividade no pensamento sociológico, almejando maior liberdade e sensibilidade na análise sobre a realidade brasileira. É através dessa noção de "sincretismo" que o autor construiu a ponte de aproximação com a tradição intelectual brasileira, valorizando autores como Gilberto Freyre ou Sérgio Buarque de Holanda por combinarem a pesquisa científica à criação literária em uma espécie de construção sincrética da qual resultaria certa unidade ao panorama da nossa cultura (CANDIDO, 1965, p. 157).

Florestan Fernandes, em contrapartida, sempre foi um crítico árduo do ensaísmo brasileiro, demarcando fronteiras com essa tradição ${ }^{10}$. Em seu balanço, o autor os associou à forma estamental da vida intelectual, (FERNANDES, 1977, p. 65), desconsiderando o ensaísmo como expressão intelectual legítima, na medida em que esses estudos negligenciaram quase que completamente a pesquisa empírica sistemática, construindo grandes generalizações a partir de critérios puramente especulativos (Idem, ibidem). Para o intelectual, a sociologia estaria na contramão desse processo, pois ela inauguraria um novo padrão de trabalho científico capaz de superar essa análise impressionista, incorporando de maneira crítica os conhecimentos produzidos em outros centros de atividade sociológica (Idem, p.71).

Para o autor, o sociólogo deveria munir-se dos métodos e técnicas adequados de investigação para construir uma interpretação rigorosa e sofisticada da realidade brasileira que fosse capaz de atender ao mesmo tempo as exigências do saber científico de caráter universal (Idem, ibidem). A defesa do estabelecimento de um padrão rigoroso e científico de trabalho visava legitimar a sociologia que, tomando distância do nosso passado intelectual, buscava delimitar seu espaço enquanto um novo campo de conhecimento. A estratégia em questão é clara: trata-se de separar radicalmente a

\footnotetext{
${ }^{10}$ Ainda que de um modo ou de outro também tivesse sido profundamente inspirado por esses trabalhos em seus estudos sobre o desenvolvimento brasileiro. Ver ARRUDA, Maria Arminda do Nascimento. "Arremate de uma Reflexão: A Revolução Burguesa no Brasil de Florestan Fernandes". Revista USP, São Paulo, v. 29, p. 56-65, 1996.
} 
ciência dos grandes ensaios, que combinavam sociologia, história e literatura, visando delimitar um espaço próprio para a sociologia diante dos praticantes concorrentes.

Através desse debate é possível apontar para um primeiro aspecto fundamental dessa fase inicial de institucionalização da sociologia brasileira, isto é, o esforço de consolidação e legitimação da disciplina como uma área de estudos autônoma e diferenciada das demais. Como abordado, o espaço institucional e intelectual da sociologia buscou ser demarcado, sobretudo, em relação aos grandes ensaios, que por longo tempo foram o solo comum que alimentaram os estudos sobre a sociedade brasileira (CANDIDO, 2006, p. 291).

As diferentes tomadas de posição assumidas por Florestan Fernandes e Antonio Candido dentro desse debate podem ser entendidas se forem consideradas também as suas origens sociais. A de Florestan, desfavorável, seria contornada por sua carreira docente na USP. Filho de empregada doméstica, o jovem intelectual concluiu o ensino médio com grandes dificuldades através do curso de madureza antes de ingressar na USP. No entanto, a despeito das dificuldades no curso, em menos de quinze anos, o sociólogo concluiu a sua graduação, o mestrado e o doutorado, fazendo da Cadeira de Sociologia I um verdadeiro grupo de intervenção, no qual se preconizou a profissionalização do trabalho acadêmico e a consolidação da sociologia como um campo de conhecimento independente, travando uma verdadeira batalha simbólica em defesa de uma abordagem declaradamente científica da sociologia. Trata-se aqui de uma figura que, desprovida de capital econômico e social, viu nas ciências sociais e na carreira acadêmica o único espaço possível para obter sucesso profissional e se afirmar socialmente $^{11}$, concentrando todas as suas forças neste investimento.

Favorecido por sua origem social privilegiada, Antonio Candido esteve desde cedo envolvido na vida cultural paulista através da sua participação na Revista Clima. Dividido entre a sociologia e a literatura (PONTES, 1998, p. 176), o autor sempre valorizou o diálogo mais estreito da sociologia com a tradição ensaística, aproximandose de uma perspectiva humanística. Ingressando na Cadeira de Sociologia II em 1942 como professor assistente de Fernando de Azevedo, não à toa vemos uma inclinação entre os membros da Cadeira de Sociologia II ao "saber desinteressado", de inspiração mais humanística e mais aberto ao diálogo com a literatura brasileira (PULICI, 2000, p.89). Esses diferentes "modelos de excelência intelectual" (Idem, p. 68) atuaram na

\footnotetext{
${ }^{11}$ Sobre período de formação de Florestan Fernandes, ver GARCIA, 2002.
} 
hierarquização das temáticas que envolveram os trabalhos na FFCL, centrando-se os estudos sobre o desenvolvimento brasileiro em torno da Cadeira de Sociologia I em contraposição aos estudos voltados para a cultura, as artes, a religião e mesmo o mundo rural, nucleados em torno da Cadeira de Sociologia II, definindo perspectivas concorrentes dentro da FFCL da Universidade de São Paulo ${ }^{12}$.

Desse modo, quando se trata de analisar as ciências sociais produzidas na USP, as disposições intelectuais-acadêmicas preconizadas por Florestan Fernandes não podem ser entendidas como o conjunto das ciências sociais produzidas naquela instituição (Idem, p.216). O que se evidenciaria seria, ao contrário, uma legitimidade obtida à custa de muitas disputas no interior da FFLC e, particularmente, com a Cadeira de Sociologia II, regida por Fernando de Azevedo (Idem, ibidem).

Outra frente de disputas bastante importante no período se deu entre a FFCL e a Escola Livre de Sociologia e Política, em torno dos estudos de comunidade. O balanço publicado por Oracy Nogueira ${ }^{13}$ em 1955 reivindicava a centralidade dos "estudos de comunidade", caracterizados como um "verdadeiro movimento intelectual, o mais vigoroso, até o momento, na história da pesquisa sociológica no País" (NOGUEIRA, 1955, p. 97). Impulsionados, sobretudo, pela ELSP, os estudos de comunidade visavam realizar um amplo quadro empírico da realidade social brasileira a partir do qual generalizações teóricas e reformas políticas seriam elaboradas. A vinda de Donald Pierson para a instituição foi fundamental. Chegando à ELSP em 1939, o intelectual imprimiu novos rumos ao projeto da escola, valorizando a ênfase na pesquisa empírica e a formação de cientistas sociais treinados para a pesquisa de campo com os estudos de comunidade se destacando como uma das perspectivas de investigação centrais da seção de pós-graduação dessa instituição.

Mesmo que esse projeto inicial não tenha ido a cabo, visto, principalmente, o afastamento de Pierson da ELSP, esse gênero de pesquisa adquiriu grande importância na escola e esteve em debate aberto com os intelectuais da FFCL-USP. A principal

\footnotetext{
${ }^{12}$ Assim que Florestan Fernandes assumiu a Cadeira de Sociologia I, ele nomeou Fernando Henrique Cardoso e Renato Jardim Moreira como assistentes; incorporando em 1955 Otavio Ianni, Marialice M. Foracchi e Maria Sylvia de Carvalho e Franco como "assistentes extranumerários". Já a Cadeira de Sociologia II reuniria, sob a chefia de Fernando de Azevedo, intelectuais como Antonio Candido, Ruy Galvão de Andrada Coelho, (enquanto primeiro e segundo assistentes), Maria Isaura Pereira de Queiroz e Aziz Simão (como auxiliares de ensino). Para uma análise mais detida sobre os perfis das duas cátedras de sociologia, ver PULICI, 2004.

${ }^{13}$ Oracy Nogueira nasceu em 1917 em Cunha, no interior de São e era filho de professores primários. Concluindo o seu segundo grau em Botucatu, o autor muda-se para São Paulo e ingressa na ELSP em 1941, onde rapidamente se tornou um aluno bolsista de Donald Pierson.
} 
polêmica se centrava em torno da forte valorização do plano empírico característico desses estudos. Assim, por um lado, os sociólogos uspianos criticaram a falta de fundamentação teórica e uma perspectiva de maior alcance nessas elaborações, desviando a atenção do observador para o processo decisivo no desenvolvimento brasileiro, que seria a formação das classes no país (JACKSON, 2007, p.38). Em resposta, os intelectuais da ELSP afirmavam que, ao contrário de relatórios puramente descritivos, os estudos de comunidade estariam inseridos dentro de um objetivo de longo alcance, isto é, o conhecimento empírico da cultura nacional brasileira (WAGLEY, 1954. p.8). Entendendo que o Brasil caracterizava-se por variações importantes no processo de desenvolvimento e modernização social, caberia ao sociólogo apreender essa diversidade (Idem, p. 7).

No entanto, para os sociólogos da USP esse intento não havia se realizado nos trabalhos dos seus idealizadores. Isso, porque no afã de analisar o processo de mudança cultural no país através do estudo quase que microscópico de uma comunidade, o pesquisador pouco descobriria acerca desse processo mais amplo, na medida em que ele estaria completamente amarrado na obsessão exclusiva de apanhar "fatos precisos" "rigorosamente obtidos" (IANNI, 1961. p.113). Valorizando, em contrapartida, a importância desse olhar mais circunscrito, Oracy Nogueira, em seu balanço, reafirmou a centralidade dos estudos de comunidade, pois estes serviriam como um "corretivo aos estudos de caráter analítico" justamente por desvendar aspectos da realidade social que muitas vezes escapam ou são minimizados por essa perspectiva de análise mais ampla (NOGUEIRA, 1955, p. 98).

O curioso é que concomitante à crítica de cunho metodológico, a ênfase na pesquisa empírica e a perspectiva supostamente "neutra" desses estudos foi posta em relação direta com posições conservadoras e reacionárias. A política e a ciência se misturaram nesse debate, servindo a primeira de princípio classificatório por parte do Florestan Fernandes e seus assistentes aos intelectuais da ELSP, demarcando-se nesse debate diferentes grupos em disputa por prestígio e hegemonia intelectual (JACKSON, 2007, p.39).

Desse modo, ainda que aliados na defesa da cientificidade da sociologia frente aos outros campos de conhecimento, os intelectuais da FFLC-USP e da ELSP divergiram acerca do método (indutivo ou dedutivo) de apreensão da realidade brasileira. Para entender esse debate é importante levar em consideração não apenas as 
posições explicitadas, mas também as diferenças na formação da ELSP - onde a influência norte-americana foi preponderante - e a Faculdade de Filosofia, Ciências e Letras (FFCL) - por sua vez modelada pelo padrão francês -, pois, mesmo integrando um projeto político comum, as duas instituições universitárias construíram projetos acadêmicos bastante distintos (LIMONGI, 1995, p. 217).

Enquanto a ELSP visava à formação de técnicos e especialistas ligados à administração pública, a FFLC priorizava a formação de uma elite intelectual, elevando o nível de cultura geral do nosso meio (Idem, p. 218-219). Enquanto a primeira teve em seu corpo docente professores provindos da tradição norte-americana da Escola de Chicago, valorizando a realização das pesquisas de campo com caráter mais "empírico", a segunda foi organizada a partir da missão francesa, atribuindo ênfase às elaborações teóricas e de caráter mais "especulativo" (Idem, p. 222-223). Essas diferenças na formação marcaram profundamente os estilos de trabalhos que foram desenvolvidos em cada uma das universidades, delimitando grupos que, em um momento de formação da sociologia no Brasil, estiveram em constante debate em torno da definição de projetos para essa disciplina.

Uma última frente de embates bastante importante do período se constituiu entre Florestan Fernandes e os intelectuais da chamada "escola paulista de sociologia" e Guerreiro Ramos, um dos fundadores do ISEB no Rio de Janeiro. Como salientou Maria Arminda do Nascimento Arruda "O debate travado entre os dois intelectuais representaria, na verdade, não apenas distinções entre o modo de conceber o desenvolvimento da reflexão sociológica no Brasil, mas, também uma disputa entre concepções que se debateram, no sentido de construir a hegemonia de orientações e de grupos" (ARRUDA, 1995, p. 154).

Negro, de origem humilde, Alberto Guerreiro Ramos nasceu na Bahia em 1915, mas mudou-se para o Rio de Janeiro no final da década de trinta para ingressar no curso de ciências sociais na recém fundada Faculdade Nacional de Filosofia. Depois de formado, disputou e perdeu consecutivamente a posição de assistente da cadeira de sociologia para Luís Costa Pinto e a de política para Vítor Nunes Leal na mesma faculdade em que se formou. Posteriormente, trabalhou no DASP como técnico de administração. Em 1952 tornou-se professor de sociologia na Escola de Administração Pública da FGV e trabalhou na assessoria econômica do governo de Getúlio Vargas. Guerreiro Ramos sempre conciliou a sua produção acadêmica com o trabalho dentro do 
funcionalismo público, afirmando-se como sociólogo no Brasil, sobretudo, após o seu ingresso no ISEB, instituto de pesquisa completamente independente da universidade (OLIVEIRA, 1995, P. 50).

No texto apresentado em 1955 no I Congresso Brasileiro de Sociologia "Esforços de teorização da realidade nacional politicamente orientados, de 1870 até nossos dias", Guerreiro Ramos apresentou o seu balanço valorizando os autores que, mesmo desprovidos dos instrumentos de rigor e metodologia científico, construíram interpretações originais que buscavam esclarecer certos aspectos da realidade brasileira. Tratava-se de obras não fundamentadas na mera transplantação de esquemas teóricos do exterior, mas que, ao contrário, buscaram formular "teorias gerais" e originais sobre a realidade brasileira ${ }^{14}$.

Esse é um ponto fundamental para o autor que examinou criticamente o pensamento social brasileiro, distinguindo a "sociologia consular ou enlatada" (acadêmica e importadora acrítica do conhecimento provindo do exterior) e a "autêntica e dinâmica" (promotora da autoconsciência e comprometida com desenvolvimento das estruturas nacionais) (RAMOS, 1957, p. 77). É contra essa concepção que insurgiu-se Florestan Fernandes em sua defesa da autonomia e universalidade do conhecimento científico. Ao contrário de "uma sociologia nacional", atrelada às demandas do processo político e social de desenvolvimento brasileiro, ele defendeu o primado da ciência (de caráter universal) na elaboração dos estudos sociológicos acerca dos nossos problemas sociais.

Para entender tais diferenças, é importante recuperar o processo de formação das universidades cariocas, pois enquanto em São Paulo a universidade esteve marcada pela relativa autonomia face aos poderes políticos, por uma hierarquia acadêmica pautada no reconhecimento do mérito científico e intelectual, sendo o lugar primeiro das realizações profissionais e sociais de seus integrantes (MICELI, 1989b, p.89); no Rio de Janeiro, as instituições acadêmicas presenciaram as constantes ingerências do poder público na administração das universidades, além de uma relação mais direta entre seus intelectuais e o sistema político (ALMEIDA, 1989, 215).

Também vinculada ao processo de modernização da sociedade, mais lento no

\footnotetext{
${ }^{14}$ De acordo com o autor, pensadores como Azevedo Amaral, Martins de Almeida e Virgílio Santa Rosa "muito acertaram porque seguiram o caminho empírico-indutivo na elaboração das suas ideias" e a seguir "constituem o mais bem sucedido esforço de teorização dos fatos ocorridos naquela faixa de tempo (década de 1930)", (RAMOS, 1957).
} 
Rio de Janeiro do que em São Paulo, a criação das instituições de ensino superior cariocas datou da década de 1930, enquanto expressão do embate entre as forças sociais envolvidas na arena político-ideológica (Idem, p.195). A primeira delas foi o ICES Instituto Católico de Estudos Superiores - impulsionada pelo Alceu de Amoroso Lima em 1932. Com o objetivo de se constituir como um catalisador da atuação dos católicos na discussão sobre o ensino superior, o ICES foi o ponto de partida do processo de criação das universidades católicas, que culminaram na fundação da Pontifícia Universidade Católica na década de 1940. Esse projeto esteve em competição direta com as iniciativas de cunho mais progressistas, como a UDF (Idem, p.196).

Criada em 1935, a UDF seguia um modelo bastante semelhante à Universidade de São Paulo. Idealizada por Anísio Teixeira, Secretário Municipal de Educação do governo de Pedro Ernesto, o empreendimento tinha como objetivo constituir a universidade como promotora da atividade científica livre e da produção intelectual desinteressada. Contudo, ainda que seja semelhante à USP na concepção, a UDF não dispunha do mesmo amparo social nas elites locais, nem respondia a anseios de camadas médias emergentes, e, por isso, logo se enfraqueceu com a saída de Anísio Teixeira, perseguido pelo governo de Vargas em 1936.

Alceu Amoroso Lima assumiu a reitoria da UDF, explicitando a clara articulação entre as lideranças católicas e o autoritarismo governante na capital carioca. Logo a universidade foi extinta e considerada uma ameaça ao Estado forte e centralizado, na medida em que a UDF se assentava na ideia de autonomia acadêmica e administrativa de cunho leigo, o que a tornaria vulnerável à "contaminação marxista" (Idem, p. 197). Em 1939 foi criada a Faculdade Nacional de Filosofia (FNFi), da Universidade do Brasil, em contraposição direta às aspirações iniciais da UDF. Ainda que absorvendo parte do quadro de professores contratados, a sua grande maioria era simpática ou comprometida com o Estado Novo e, dentre os professores estrangeiros admitidos, praticamente todos eram ligados ao pensamento católico (Idem, p.198). Sem atividades de pesquisa de grande destaque, a FNFi, no entanto, formou importantes intelectuais, como Guerreiro Ramos e Costa Pinto que viriam a ocupar um papel fundamental na sociologia nos anos seguintes.

É dentro desse contexto de forte polarização política que o Instituto Superior de 
Estudos Brasileiros (ISEB) foi fundado. Criado em $1955^{15}$ como um instituto vinculado ao Ministério da Educação e da Cultura - ainda que gozasse de plena autonomia - e aglutinando intelectuais como Hélio Jaguaribe, Nelson Werneck Sodré, Guerreiro Ramos e Costa Pinto, o ISEB apareceu como uma das alternativas de pesquisa e produção intelectual independente na área das ciências sociais, até então, fortemente controlada pelos setores católicos. Como afirma Maria Hermínia T. de Almeida, a diversificação institucional se apresentou como uma estratégia frente à dificuldade de assentar raízes sólidas para a pesquisa acadêmica, haja vista as fortes turbulências políticas pelas quais passavam as universidades cariocas (ALMEIDA, 1987, p.49).

No entanto, mesmo no interior do ISEB, a situação se diferenciava bastante daquela vivenciada na Universidade de São Paulo. Isso, porque enquanto na segunda, os cientistas sociais encontravam na universidade um emprego de tempo integral, derivando do seu trabalho acadêmico a sua posição e prestígio social; os integrantes do ISEB sempre conciliaram as suas atribuições nesse instituto com diversas outras atividades (negócios, cargos políticos ou no funcionalismo), pois, em sua maioria, eram membros reconhecidos das elites políticas e culturais. Assim, não é de se estranhar que em São Paulo se impôs uma preocupação metodológica e teórica mais acentuada, visando à apreensão científica da realidade social, enquanto no Rio de Janeiro o caráter militante da sociologia se destacou, construindo-se, na capital carioca, uma hierarquia de objetos e problemas pautada na sua relevância para o debate político nacional (MICELI, 1989b, p.84).

O contraponto entre em São Paulo e Rio de Janeiro revela, portanto, a existência de diferentes projetos para a sociologia brasileira. Se para Florestan Fernandes a sociologia deveria estar comprometida com a instauração de um novo padrão de reflexão científico, Guerreiro Ramos a compreendia alicerçada a uma prática ideológica e política que visasse atuar na promoção do desenvolvimento nacional (RAMOS, 1957, P. 79). Para esse segundo autor, a relação entre a sociologia e a prática política constituía um dos pilares da sua proposta. Assim, ele afirmou que: "A promoção da autoconsciência de cada sociedade latino-americana constitui um dever primacial de seus respectivos sociólogos" (Idem, p. 83) e tem a obrigação de estar sempre

\footnotetext{
${ }^{15}$ O ISEB foi fundado em 1955 em substituição ao Instituto Brasileiro de Economia, Sociologia e Política (IBESP) criado em 1953. Esse instituto se formou a partir do "Grupo de Itatiaia", uma reunião de intelectuais do Rio de Janeiro e de São Paulo que acontecia desde 1952 no Parque Nacional de Itatiaia e cujo propósito era discutir os rumos do desenvolvimento nacional. Grande parte dos participantes desse grupo viria a integrar posteriormente o ISEB (TOLEDO, 1978, p. 32).
} 
comprometida uma ação política de sentido verdadeiramente nacional, nos libertando da incisiva exploração dos capitais estrangeiros (Idem, p. 69).

Ainda que não deixe de vislumbrar na sociologia um papel crítico, na década de 1950, Florestan Fernandes se contrapôs a esse projeto, reivindicando a autonomia da disciplina frente aos interesses políticos imediatos em jogo na agenda nacional, subordinando o conhecimento sociológico aos padrões e exigências científicos de caráter universal. Para o paulista, "nenhum cientista conseguirá pôr a ciência a serviço de sua comunidade, sem observar, de modo íntegro e rigoroso as normas e valores que regulam a descoberta, a verificação e a aplicação do conhecimento científico" (FERNANDES, 1977, p.68).

Esse tipo de posicionamento de cunho mais cientificista também encontrou guarida no Rio de Janeiro, o que permite matizar essa polarização entre o Rio e São Paulo. Um dos sociólogos mais reconhecidos nessa direção é Luiz de Aguiar Costa Pinto. Nascido na Bahia (assim como Guerreiro Ramos), Costa Pinto, ao contrário de seu conterrâneo, proveio de uma família tradicional cujo pai foi médico e professor universitário. Com o falecimento do patriarca em 1936, ele se mudou para o Rio de Janeiro em 1937 e ingressou no curso de ciências sociais da Faculdade Nacional de Filosofia, da Universidade do Brasil. Tornando-se docente dessa instituição na década de 1940, o autor participou do projeto da UNESCO sobre as relações raciais no Brasil na década de 1950, constituindo-se como um pesquisador reconhecido nacionalmente e chegando a ocupar o cargo de presidente da Associação Brasileira de Sociologia em 1954.

Reconhecido pelo seu esforço de consolidar um espaço específico para a sociologia como uma disciplina científica no país (SORJ, 1999, p. 223), Costa Pinto elaborou o seu balanço a pedido da CAPES com Edson Carneiro em 1955, quase ao mesmo tempo em que foram publicados os de Florestan Fernandes (1956 e 1958) e Guerreiro Ramos (1955). Assim como o paulista, Costa Pinto considerou a revolução de 1930 como o marco zero da sociologia brasileira (PINTO; CARNEIRO 1955, p.11), entendendo a criação dos primeiros cursos de ciências sociais nas universidades como o que haveria de mais positivo até aquele presente momento (Idem, ibidem). As universidades teriam possibilitado o desenvolvimento do ensino e da pesquisa na área, formando cientistas sociais que teriam caminhado no sentido da superação da mentalidade literária e das grandes generalizações sem fundamento científico (Idem, p. 
43).

Costa Pinto buscou diferenciar a sociologia não apenas dos grandes ensaios, mas, inclusive, de outras áreas do saber vizinhas a essa disciplina. Assim como Florestan Fernandes, o autor criticou também os estudos de comunidade, entendendo que esses trabalhos padeciam de incapacidade de ver a comunidade como um todo, organizando-se em torno de um conceito pouco definido de cultura (Idem, p. 64). Defendendo a relevância da sociologia em contraste com a antropologia, o autor argumentou que faltaria a essa disciplina o esquema conceitual e rigor metodológico para produzir estudos de alcance mais amplo.

Costa Pinto se envolveu também em diversas polêmicas com Guerreiro Ramos. Nesse mesmo período, os autores haviam divergido ao discutir a questão das relações raciais e do preconceito ${ }^{16}$. Nos debates acerca do papel da sociologia no Brasil também não foi diferente. Em seu balanço, o sociólogo valorizou a vinda de estrangeiros para compor o quadro docente nas universidades, entendendo que tal colaboração longe de representar uma "humilhação nacional", tal como via Guerreiro Ramos, representaria uma etapa comum e necessária em todos os campos de conhecimento nascentes nos mais diversos países (PINTO; CARNEIRO, 1955, p. 47). Na verdade, a reação contra a sua influência refletiria, ao contrário, o medo dela e a força do nosso "complexo colonial" (Idem, ibidem).

Do mesmo modo, o autor buscou problematizar a associação direta estabelecida por Guerreiro Ramos entre a sociologia e os "interesses verdadeiramente nacionais" de desenvolvimento, entendendo que: "O nacionalismo põe toda a ênfase no inimigo externo. É antiimperialista - e isto eu também sou. Mas eles subestimam - o que eu não faço - os obstáculos internos ao desenvolvimento" (PINTO, apud, OLIVEIRA, 1995, p. $300)$.

Buscando definir as fronteiras da sociologia, tanto em relação às outras ciências, como em relação aos discursos políticos e ideológicos em voga, Costa Pinto foi se consolidando como uma figura central no desenvolvimento dessa disciplina no Rio de Janeiro na década de 1950, estabelecendo uma relação diferenciada entre a sociologia e

\footnotetext{
${ }^{16}$ Isso, porque, enquanto Guerreiro Ramos apostava na constituição de uma intelectualidade engajada, cujo exemplo mais significativo seria o Teatro Experimental Negro, como passo imprescindível para a superação da discriminação racial, Costa Pinto vislumbra esse processo sobretudo a partir de mudanças estruturais na sociedade. Trata-se aqui da ênfase estabelecida em cada um dos casos, seja do sujeito político, no caso do primeiro, seja da estrutura social, no caso do segundo (MAIO, 1997, p. 155).
} 
a política. Isso, porque enquanto o ISEB realizou essa ponte de maneira mais direta, envolvendo-se completamente na construção de um projeto de desenvolvimento nacional, Costa Pinto o fez indiretamente, participando de iniciativas internacionais de pesquisa na área, alinhadas com a agenda internacional de desenvolvimento na América Latina, como é o caso do Clapcs (Centro Latino Americano de Ciências Sociais) no Rio de Janeiro, dentro do qual Costa Pinto foi diretor e editor de sua revista (BLANCO; JACKSON, 2014, p.89) ${ }^{17}$.

Todos esses embates entre os sociólogos de São Paulo e do Rio de Janeiro revelam uma dimensão central da fase de fundação das ciências sociais no Brasil: definir o significado da sociologia e os objetivos a serem perseguidos por seus praticantes no Brasil - dinâmica esta explicitada nos próprios "balanços" acima analisados. A década de 1950 constituiu um rico período no qual se entrecruzaram e se confrontaram distintas perspectivas para essa disciplina, movidas pela necessidade de legitimação. Tendo como eixo a temática da modernização e do desenvolvimento brasileiros (JACKSON, 2007), os cientistas sociais do Rio de Janeiro e São Paulo centralizaram os esforços na constituição dessas disciplinas, sobretudo, a partir da Universidade de São Paulo, da Escola Livre de Sociologia e Política, da Universidade do Brasil e do ISEB.

Deve-se notar ainda que nessas primeiras décadas, a sociologia tinha papel proeminente, cabendo à ciência política e à antropologia posições secundária na hierarquia disciplinar que se constituiu nesses anos. Não por acaso, todos os balanços levantados se propuseram a reconstituir e problematizar a situação da sociologia especificamente. Até 1964 não apenas a ciência política encontrava-se em uma zona ainda pouco definida entre a sociologia e o direito, como, inclusive, a própria antropologia estava em um momento bastante incipiente de desenvolvimento e já desde a década de 1940 recebia críticas como às expressas por Costa Pinto anteriormente e também por Florestan Fernandes que, na mesma direção, afirmou que "falta à antropologia os meios de investigação para apanhar as correlações mais profundas entre os tipos de estratificação social e os conteúdos culturais correspondentes”, por isso, a

\footnotetext{
${ }^{17}$ No entanto, é importante salientar que, embora se aproxime de uma perspectiva de cunho mais cientificista, para Costa Pinto, a política continua a ter um peso importante no desenvolvimento da sociologia. Não à toa, ao contrário dos paulistas, Costa Pinto analisou com pessimismo os anos 1935 até 1937 dentro da sociologia, entendendo essa fase como uma "reação obscurantista que, a partir do meio do decênio, quase liquidou o que se havia conquistado no lustro anterior" (PINTO; CARNEIRO, 1955, p. 24).
} 
sociologia seria "entre as ciências humanas, a que mais tem acumulado conhecimento sobre a organização e mudanças sociais nas sociedades ocidentais" (FERNANDES, 1948, p. 78). Tal configuração foi significativamente modificada a partir do golpe militar de 1964 com a criação dos institutos e os programas de pós-graduação especializados pelo país.

\section{Censura e cultura}

O desenvolvimento das ciências sociais após 1964 foi marcado por profundas transformações e resultados bastante contraditórios para as ciências sociais. De maneira geral, é possível entender a política adotada pelos governos militares desde dois ângulos distintos. Por um lado, destacou-se a política de desarticulação das principais lideranças da sociologia brasileira com as aposentadorias compulsórias na Universidade de São Paulo, a censura de publicações e o controle sobre as atividades acadêmicas. No Rio de Janeiro, o ISEB, epicentro da produção sociológica carioca, foi fechado dias depois do golpe e seus integrantes convocados para um inquérito policial-militar para apuração das atividades do grupo. Logo em seguida, alguns de seus principais integrantes, como Helio Jaguaribe, Guerreiro Ramos e Álvaro Vieira Pinto saíram do país para lecionar no exterior.

Por outro lado, é preciso lembrar que foi também nesses anos que as universidades brasileiras foram objeto de grande investimento por parte do Estado. Diante de uma conjuntura marcada pelo desenvolvimento econômico, a formação de mão-de-obra qualificada com escolaridade superior passou a se colocar como prioridade na agenda educacional do país (CUNHA, 1988, p. 156). É diante desse cenário que os debates em torno da reforma universitária, que se iniciaram no começo da década de 1960, ganharam força depois do golpe, tendo os seus trabalhos concluídos em 1968.

Orientada por uma comissão formada por norte-americanos (United State Agency for International Development - Usaid) que, em parceria com o MEC, buscava repensar o ensino superior brasileiro, a reforma universitária foi responsável por grandes transformações nas universidades brasileiras. A primeira delas diz respeito à expansão no número de vagas abertas pelas universidades. Diante da demanda crescente no Brasil, o governo militar ampliou as vagas e o número de instituições de ensino superior 
no país como nunca antes na história. Assim, dentro de um intervalo de quinze anos (1965-1980), o número de vagas disponibilizadas para os alunos concorrentes ao ingresso nas universidades cresceu de 39 mil para 279.3 mil (SCHWARTZMAN, 1979, p. 25). As federais, que já vinham se expandindo no Brasil desde a década de 1950, também cresceram em número, ainda que a sua maioria tenha se originado da agregação de faculdades, escolas e institutos já existentes. O Estado, portanto, aumenta a sua participação na manutenção do ensino superior, seja pela federalização, seja pelo aumento de vagas nos estabelecimentos oficiais ${ }^{18}$. As ciências sociais usufruíram desse contexto, expandindo os seus cursos por todo o país e ampliando a pesquisa e a pósgraduação, que até então teve expressão apenas no eixo Rio de Janeiro/São Paulo em poucos de centros de ensino e pesquisa voltados, principalmente, para a sociologia.

Inspirada no modelo norte-americano de universidade, a reforma se orientou não apenas para a elevação do contingente de estudantes na graduação e pós-graduação, mas também para a organização dos cursos e da universidade. Desse modo, o sistema de cátedras, centralizado na figura de seu titular (vitalício em seu cargo) - o único responsável pela contratação, demissão e determinação das atividades de ensino e pesquisa de seus assistentes e auxiliares - é substituído pelo departamental visando à ampliação e racionalização da estrutura das universidades brasileiras (CUNHA, 1988, p.230). Do mesmo modo, as disciplinas passariam a ser oferecidas pelos departamentos e contabilizadas sob a forma de créditos.

Paralela a essas medidas, cabe destacar a criação de um sistema nacional de pósgraduação, aliado à unificação do ensino e da pesquisa que até então estavam apartados em muitos estados do país, além da adoção do regime exclusivo de trabalho dos docentes nas universidades. Todas essas medidas visavam incentivar o desenvolvimento científico e tecnológico no país, formando uma nova elite intelectual que deu continuidade a sua especialização acadêmica, seja no exterior como apoio financeiro do poder público, seja nos programas de pós-graduação que foram sendo criados no país (MICELI, 1995, p.14). Trata-se aqui de um momento importante na institucionalização da atividade científica brasileira, do qual as ciências sociais se beneficiaram fortemente.

\footnotetext{
${ }^{18}$ É importante ponderar que o reconhecimento das universidades enquanto federais assim como a distribuição de recursos entre elas eram mediados pelo Conselho Federal da Educação, o que acarretou grandes disputas entre os dirigentes universitários (CUNHA, 1989, p. 93). O decreto-lei no 53, aprovado por Castelo Branco em 1966 - que fixou princípios e normas de organização das federais -, previa, por exemplo, que todas as universidades federais (tanto as já instaladas como as que pretendessem alçar essa posição) teriam o seu Estatuto submetido à CFE para aprovação, devendo-se adequar às normas $\mathrm{e}$ disposições previstas pelo governo (BRASIL, decreto-lei no 53, de 18 de Novembro de 1966).
} 
Por fim, cabe sublinhar a importância da Fundação Ford no financiamento de muitos desses empreendimentos. Com atuação decisiva na América Latina a partir do início da década de sessenta, a Fundação se propunha a influenciar a gestão dos processos de desenvolvimento em países periféricos, estabelecendo como beneficiários de tais aportes tanto o aparato governamental das nações atendidas, como suas instituições de ensino e pesquisa, com ênfase nessas últimas (MICELI, 1995, p. 360). Em um contexto internacional de "guerra fria", essa instituição financiou diversas iniciativas de pesquisa no Brasil, descobrindo nas ciências sociais um possível mercado emergente e fazendo dessa área de pesquisa a privilegiada das suas dotações. Vistas como conjunto de saberes fundamentais para o processo de modernização na América Latina (Idem, p. 377), a sociologia, a ciência política e a antropologia conseguiram obter generosos recursos com destaque para a área de ciência política que chegou a abocanhar cerca de $50 \%$ do total destinado às ciências sociais (FIGUEREIDO, 1988, p. 48).

Desse modo, a Fundação Ford constituiu um dos principais propulsores da expansão das ciências sociais nesse período através da concessão de bolsas de estudo para os centros de excelência no exterior, promovendo a vinda de professores ao Brasil e financiando importantes institutos de pesquisa e pós-graduação na área. A primeira instituição que recebeu recursos da Ford foi o DCP-UFMG, organizado em 1967, que também constituiu o primeiro programa de mestrado em Ciência Política no Brasil. Em seguida vem o IUPERJ, que faz o mesmo em 1969 e que recebe o segundo maior volume de recursos da Fundação (U\$1.671.323) durante a vigência do seu convênio, seguido apenas do Cebrap (U\$1.721.200), que iniciou as suas atividades no mesmo ano (MICELI, 1993, p.17).

Nesse sentido, as ciências sociais estavam inseridas no final da década de sessenta no cenário definido por Renato Ortiz como conjunturalmente contraditório entre a censura e a cultura (ORTIZ, 1990, p.171). Articulando o investimento nessa área e a repressão aos cientistas sociais, o regime militar foi responsável pelo afastamento de diversos professores na universidade e, ao mesmo tempo, pela entrada na carreira docente de toda uma nova geração de cientistas sociais. Como afirma Renato Ortiz: “(...) minha geração tem a tendência a negligenciar certos fatos incômodos, afinal, foi este o momento em que encontramos espaço na vida universitária. É patente que o quadro institucional foi construído à base da exclusão (...) e inclusão de novos profissionais" (Idem, p.172). 


\section{Ciência Política versus Sociologia}

Um dos resultados mais importantes desse novo contexto é a legitimação da ciência política como uma disciplina autônoma nas ciências sociais brasileiras. Tendo em vista o forte investimento nos centros de pesquisa e pós-graduação aliados a uma conjuntura de intervenção e restrição dos direitos políticos com o regime militar brasileiro, essa disciplina ganhou um grande impulso no país (KEINERT, 2011, p.14).

Os institutos de pesquisa centralizaram esse processo contando com as maiores dotações da Fundação Ford para se estruturarem. Como aponta Fabio Keinert, as instituições de pesquisa adquiriram uma posição estratégica dentro das ciências sociais brasileiras. Tendo em vista a ausência dos encargos de ensino na graduação, as fontes diversificadas de financiamento, os projetos coletivos de investigação e a divisão de tarefas, estes experimentos destacaram-se como alternativas de organização e produção acadêmica em tempos de forte desconfiança política sobre as ciências sociais (Idem, p. $56)$.

O Iuperj ganhou notável importância no Rio de Janeiro. Patrocinado pela Fundação Ford desde 1969, o instituto agregou um amplo conjunto de pesquisadores cariocas e mineiros, constituindo juntamente com o DCP da UFMG o núcleo central da institucionalização da ciência política no país. No contexto carioca, cabe ainda pôr em evidência que desde a década de 1950, a universidade restringiu-se praticamente ao ensino no domínio das ciências sociais, justamente em função da fragilidade de sua própria constituição (ALMEIDA, 1989, p.214). Mesmo depois do golpe militar e a reformulação e criação de novas instituições universitárias no Rio de Janeiro ${ }^{19}$, o seu forte estreitamento com os grupos políticos em disputa acabou cerceando as suas possibilidades de constituição como espaço de ensino e pesquisa autônomo.

Conjuntamente com o crescimento e reconhecimento do Iuperj no Rio de Janeiro, as ciências sociais em Minas Gerais ganharam também um novo impulso a partir dos estudos na área de ciência política promovidos pelos intelectuais nucleados em torno da UFMG. Esta universidade se inseriu, no entanto, com atraso no cenário acadêmico do país. Ainda que tenha sido fundada em 1927, como resultado da

\footnotetext{
19 A Universidade do Brasil, por exemplo, foi renomeada UFRJ em 1965, tendo como o seu primeiro reitor, o médico Raymundo Augusto de Castro Moniz de Aragão também Ministro da Educação do governo Castelo Branco.
} 
agregação de escolas e faculdades anteriormente existentes, foi apenas no final da década de quarenta, com a federalização da universidade e certo movimento por parte das elites intelectuais no sentido de superar a estagnação e o atraso regional do estado (ARRUDA, 1995, p. 249), que as ciências sociais encontraram solo fértil para germinar, se transformando em uma necessidade política. O curso de Sociologia e Política iniciou seu funcionamento em 1953 vinculado à Faculdade de Ciências Econômicas e Administrativas de Minas Gerais, o que exerceu significativa influência na formação de seus estudantes desde sua grade disciplinar afinada com os cursos de direito, economia e administração (Idem, p. 260). Tendo em vista a anexação do curso de Sociologia e Política à Faculdade de Filosofia da universidade após a instauração do regime militar, o Departamento de Ciência Política foi criado em associação com a Fundação Ford ainda na década de sessenta, sendo primordialmente pensado como o espaço a partir do qual se daria continuidade, ao nível de pós-graduação, àquele curso pioneiro (FORJAZ, 1997, p.7).

São muitas as aproximações entre o caso carioca e mineiro. Para além de abrigo acadêmico, outro aspecto merece ser destacado com o intuito de iluminar as possíveis afinidades entre as disposições intelectuais de mineiros e cariocas. Trata-se da aproximação visível de seus contextos intelectuais e institucionais, pois apesar das especificidades, ambas as experiências desenrolaram-se de forma muito próxima à esfera política. A inclinação para a política dos mineiros (ARRUDA, 1989, p. 274), expressa na sua sensibilidade e predileção pela política, encontrou eco na tradição intervencionista e militante das ciências sociais no Rio de Janeiro, imensamente marcada pela experiência isebiana (MICELI,1989, p.92). A criação de um instituto de pesquisas cuja base disciplinar seja a própria ciência política foi vista como estratégia atrativa para esses dois grupos de intelectuais ancorados numa concepção de ciências sociais na qual a política foi extremamente valorizada (FORJAZ, 1997, p.11).

Desse modo, não é de se estranhar os primeiros balanços disciplinares sobre a ciência política tenham sido redigidos por intelectuais formados nessas instituições. Wanderley Guilherme dos Santos formou-se em pequenas escolas particulares do Rio de Janeiro, graduando-se na FNFi em 1958 e sendo convidado à integrar o ISEB no final da década de cinquenta. Com o seu fechamento em 1964, Santos ajudou a fundar e se tornou pesquisador do Iuperj, realizando o seu doutoramento nos Estados Unidos através de uma bolsa da Fundação Ford anos depois. Já Bolívar Lamounier graduou-se 
no Curso de Sociologia e política da UFMG e, assim como Santos, obteve uma bolsa para realizar o seu doutorado nos Estados Unidos. Retornando ao país no fim da década de 1970, ele se integrou ao Iuperj, como parte dos intelectuais mineiros que migraram para o Rio de Janeiro durante o período militar.

O texto de Wanderley Guilherme dos Santos ${ }^{20}$ inicia-se agrupando os "balanços disciplinares" produzidos em três modalidades principais - a matriz institucional, a sociológica e a ideológica -; delimitando a sua crítica ao paulista Florestan Fernandes. Para Santos, Florestan - enquadrado na matriz institucional - entenderia o desenvolvimento do pensamento social no país segundo critérios puramente institucionais, enxergando na adoção dos padrões científicos de investigação, promovidos com a implementação da disciplina nas universidades, como o único critério de avaliação da qualidade do pensamento produzido. O problema dessa perspectiva estaria na superficialidade com a qual trataria o problema. Para o pesquisador carioca, a matriz institucional ordenaria o passado em função do presente, desvalorizando ou dispensando qualquer investigação mais profunda acerca de todo o pensamento considerado "pré-científico" (SANTOS, 1978, p. 27). Lamounier concordou inteiramente com essa avaliação, entendendo que tal posição teria levado à associação da "apreensão correta da realidade" à "assimilação da parafernália acadêmica (...) e não ao conteúdo substantivo das interpretações" (LAMOUNIER, 1977, p.349).

Assim, ambos os autores buscaram reconstituir a história das ciências sociais tendo em vista o conteúdo manifesto em seus trabalhos. A partir da análise das obras, Santos sugeriu que "Desde a Independência o problema teórico e prático predominante (...) tem sido fundamentalmente este: de que modo implementar e garantir eficiente funcionamento da ordem liberal burguesa" (SANTOS, 1978, p. 50). O debate acerca da condição de ciência é deslocado para dar lugar a um esforço no qual importaria entender o nosso passado intelectual desde um prisma mais diretamente político, isto é, a materialização da ordem burguesa no país.

Através desta reinterpretação do nosso pensamento social, o autor construiu uma tradição a partir da qual a ciência política poderia se edificar no Brasil. Lamounier se utilizou da mesma estratégia. Recuperando a tradição do pensamento autoritário da

\footnotetext{
${ }^{20} \mathrm{O}$ artigo de Wanderley Guilherme dos Santos conta com diferentes versões publicadas. A utilizada como base para esse capítulo é "Paradigma e história: a ordem burguesa na imaginação social brasileira", in Ordem Burguesa e Liberalismo Político. 1. ed. São Paulo: Duas Cidades, 1978.
} 
Primeira República como "matéria mais candente do que se poderia chamar de história do pensamento político no Brasil" (LAMOUNIER, 1977, p. 347), o autor vislumbrou nessa tradição as primeiras reflexões no sentido de legitimar a autoridade do Estado como princípio tutelar da sociedade (Idem, p. 356).

Apesar das divergências, os dois autores reivindicaram a importância da ciência política. Como concluiu em seu balanço sobre a disciplina, existiria entre a ciência política e o pensamento político brasileiro não apenas "uma notável continuidade como, sobretudo, parece-me possível afirmar que o prestígio dessa tradição legitimou (...) o desenvolvimento da ciência política, a partir de 1945" (LAMOUNIER, 1982, p. 409). Ao contrário de autores como Florestan, que tomaram como ponto de partida a diferenciação daquilo que o antecedia - como apontado em relação ao ensaísmo - Santos e Lamounier recorreram à história do nosso pensamento, valorizando-a ao invés de clamar pela sua superação, tal como foi característico no período anterior.

Ao mesmo tempo, é importante destacar que essa reinvenção das raízes da ciência política se fez a partir da dissociação entre a formação da especialidade e o seu processo de institucionalização, entendendo os primórdios e o desenvolvimento dessa disciplina desde um período anterior ao da sua consolidação nas universidades. Para firmar o lugar da disciplina diante das suas concorrentes, esse movimento se fez ainda mais necessário, uma vez que a consolidação da ciência política nas universidades foi recente, adquirindo um forte impulso apenas depois de 1964.

É, portanto, somente nesse período que a ciência política brasileira passou a adquirir maior densidade, delimitando-se como uma área de investigações mais estruturada e definida. Atribuindo esse "ato fundador" aos institutos de pesquisa e à criação dos programas de pós-graduação, Lamounier destacou que foi somente através do apoio da Fundação Ford aos programas de pós-graduação na especialidade e da sua institucionalização no IUPERJ, na UFMG no CEBRAP que a mesma pôde consolidarse (Idem, p. 422).

Todas essas transformações institucionais atuaram de modo a promover uma forte dinamização dos estudos na área. Buscando avaliar o desenvolvimento da ciência política no país, Lamounier concluiu, conjuntamente com Fernando Henrique Cardoso, que diante deste novo cenário, a disciplina teria ampliado o seu leque temático, renovando as suas linhas de pesquisa, ao mesmo tempo em que incorporou referências de outras correntes do pensamento, tais como a norte-americana, garantindo o 
refinamento na utilização das técnicas de pesquisa quantitativa nas produções recentes daquele contexto (CARDOSO; LAMOUNIER, 1978). Como veremos a seguir, não apenas a ciência política, mas também a antropologia passou por fortes modificações, buscando firmar o seu espaço dentro das ciências sociais brasileiras.

\section{A antropologia nas ciências sociais}

O "balanço" realizado pelo antropólogo vinculado ao PPGAS do Museu Nacional, Roberto Cardoso de Oliveira começa dividindo a história da antropologia no Brasil em três momentos: o "heróico", no qual a profissão de antropólogo e o próprio campo antropológico ainda não estavam institucionalizados; o "carismático", por sua vez, caracterizado por intelectuais como Florestan Fernandes e Darcy Ribeiro que passariam a "reunir em torno de si e de seus projetos científicos e acadêmicos inúmeros jovens estudantes de antropologia" (OLIVEIRA, 1988, p. 113), em um momento da disciplina marcado pela sua forte associação com a sociologia (Idem, p.115); e o "burocrático", período em que o carisma daquelas lideranças "se rotiniza" e surgem novas formas de divisão do trabalho que visam racionalizar os projetos de formação avançada em antropologia (Idem, p. 113). O período burocrático representaria, então, um momento no qual a disciplina passaria por profundas transformações, permitindo o seu amadurecimento e maior autonomização, mesmo inscrita no conjunto formado com a sociologia e a ciência política no país.

O movimento realizado por Roberto Cardoso de Oliveira verifica-se em maior ou menor medida nos "balanços" realizados pelos cientistas políticos. Reivindicando uma tradição e avaliando o desenvolvimento da antropologia e da ciência política, esses autores buscaram legitimá-las dentro das ciências sociais. O "balanço" realizado por Julio Cesar Melatti e publicado no BIB em 1984 seguiu a mesma direção. Assim como Oliveira, o autor busca reconstruir a história da antropologia no Brasil, identificando o início da disciplina no Brasil nas crônicas e relatos de viajantes missionários e diplomatas produzidas no século XVI. Essa datação é justificada na medida em que, mesmo não sendo cientistas sociais, estes autores teriam produzido registros de observações diretas e espontânea dos povos que ali viviam (MELATTI, 1984, p.3).

Percorrendo a nossa tradição intelectual, ele enxergou na década de 1960 o 
momento de um novo impulso para a antropologia, pois com a expansão do ensino e a institucionalização da sua pós-graduação no Brasil, começaram a crescer também a quantidade de pesquisadores formados especificamente nos programas de pósgraduação em antropologia, transformando e ampliando os estudos dessa disciplina e delimitando, diante da sociologia, o seu próprio campo de reflexão e de atividade (Idem, p. 17).

Gilberto Velho, em outro balanço sobre formação da antropologia, atinou para a mesma questão. Identificando uma origem antiga da disciplina dentro da produção intelectual brasileira, o autor afirmou que a institucionalização da antropologia com um viés mais profissional e profissionalizante se fez apenas recentemente, na década de 1960 (VELHO, 1980, p.1). Esse teria sido um momento profundamente representativo desse desenvolvimento, pois foi apenas com a criação da pós-graduação de antropologia em diferentes institutos de pesquisa e universidades que o caráter de "grupo de amigos" dos pesquisadores antropólogos foi se transformando em direção a uma comunidade acadêmica e científica melhor estruturada (Idem, p. 2). A criação do PPGAS no Museu Nacional (1968) foi imprescindível nessa direção.

Idealizado e impulsionado por Roberto Cardoso de Oliveira, o PPGAS do Museu Nacional adquiriu forma a partir do contato de Oliveira com o antropólogo David Maybury-Lewis quando era pesquisador no Museu do Índio no Rio de Janeiro. Em 1962, eles assinaram o convênio com a Harvard Central Research Project, dedicado ao estudo das populações indígenas no Brasil, reunindo os pesquisadores da universidade norte-americana e a equipe nucleada no curso do Museu Nacional (KEINERT, 2011, p.76). Em 1966, momento em que Roberto Cardoso e David Maybury-Lewis decidiram buscar o apoio da Fundação Ford, o acadêmico inglês já desfrutava da autoridade científica condizente com o cargo de professor em Harvard (1960), além de ter se tornado consultor da agência norte-americana, o que, evidentemente, colaborou para a assinatura do convênio com a Fundação anos depois (Idem, ibidem).

A criação do PPGAS no Museu Nacional transformou decisivamente a posição da antropologia no cenário das ciências sociais brasileiras ao se configurar como um programa de pós-graduação conceituado e voltado para a formação acadêmica de pesquisadores na área. Tal experiência teve grande influência da prática de ensino e pesquisa consolidadas na USP. Como lembra Roberto Cardoso de Oliveira: 
"Eu sentia como um prolongamento da minha formação de aluno da USP, pautada na ideia do tempo integral, da ética do normalien da escola francesa. E no Rio de Janeiro, não havia uma grande tradição de tempo integral. Acho que, no Rio, o Museu foi o primeiro a criar esse padrão em que a pesquisa e o ensino estão muito associados. Os alunos todos tinham recursos para a pesquisa e pesquisa em antropologia não é barata" $(\text { OLIVEIRA, 1993) })^{21}$.

Desse modo, a antropologia começou a ganhar espaço enquanto disciplina autônoma e científica dentro das ciências sociais brasileiras, ampliando a sua presença nacionalmente com a criação do programa de mestrado na UNICAMP (1971), na Universidade de Brasília (1972), além da remodelação da pós-graduação já existente na USP (1970). A despeito das diferenças entre cada uma dessas instituições, é importante pôr em relevo as suas semelhanças na medida em que elas apontam para o mesmo processo em curso. Em primeiro lugar, todas essas instituições foram responsáveis pela ampliação da pesquisa antropológica no país, cujos estudos se multiplicaram nesse período, especialmente sobre a temática dos povos indígenas e dos camponeses, impulsionados principalmente a partir do Museu Nacional (CORRÊA, 1995, p.49). Enquanto cursos de pós-graduação, essas instituições também foram responsáveis pela formação teórica e acadêmica de dezenas de mestres e doutores, modelando de acordo com o perfil dessas instituições uma importante geração de novos pesquisadores. E, sobretudo, foi a partir desses cursos que a antropologia pode se constituir como especialidade reconhecida no meio acadêmico, dotada de problemas e conceitos característicos, criando um léxico próprio (Idem, p. 78).

Dentro desse espaço de forte dinamismo, as temáticas dentro da disciplina também se renovaram. Melatti enfatizou o destaque dos estudos sobre os camponeses, sobre os índios e sobre os trabalhadores assalariados rurais e urbanos que foram surgindo, em parte também contra a perspectiva traçada pelos estudos de comunidade e, também, contra a sociologia uspiana e a sua visão generalizante de desenvolvimento que por vezes detinha pouca ou insuficiente atenção às particularidades do campo e das comunidades indígenas (MELATTI, 1984, p. 7). Neste ambiente de clara redefinição das áreas de conhecimento, surgiram a antropologia urbana, a antropologia médica ou

\footnotetext{
${ }^{21}$ Entrevista de Roberto Cardoso de Oliveira concedida a Fausto, Leite, Weingrill \& Costa (1993).
} 
da saúde e a antropologia física, indicando o início da especialização dentro da própria antropologia.

Explorando os precursores do pensamento social brasileiro, todos os balanços abordados buscaram formular uma história da antropologia no Brasil, recuperando e reinventando as raízes dessa disciplina no país. Assim como no caso dos textos produzidos na ciência política, a década de 1960 foi identificada como um momento central para a consolidação dessas disciplinas a partir da fundação dos programas de pós-graduação especializados nessas áreas e dos institutos de pesquisa. Desse modo é que, tomando a sociologia paulista como adversária nesse cenário, tanto os cientistas políticos quanto os antropólogos cariocas reivindicam para si o "ato de fundação" dessas disciplinas como área do saber especializada, menosprezando a experiência paulista dos anos anteriores na Universidade de São Paulo (dentro da Cadeira de Antropologia e de Política) e na ELSP.

No entanto, quando comparados, é possível identificar uma clara diferença nos tons utilizados em cada um deles no que tange ao posicionamento frente à sociologia produzida na USP. Isto, porque os balanços publicados em defesa da ciência política foram mais agressivos e com fortes críticas à sociologia uspiana. A hipótese aqui aventada é que tal posicionamento se relacionaria a maior fragilidade institucional dessa disciplina no país, o que exigiu, por sua vez, um embate mais duro - principalmente com a dominante sociologia - para se legitimar.

Tomando-se como exemplo a situação das Cadeiras de Antropologia e de Política na Universidade de São Paulo, essa assimetria é bastante clara. Isso porque diante das alterações das cátedras promovidas pela ditadura de Vargas no início da década de 1940, foram criadas tanto as Cadeiras de "Antropologia" como a de "Política" 22 . Enquanto a Antropologia se afirmou criando a Revista de Antropologia já em 1953; a Ciência Política - designada somente como "Política" - ainda permaneceu nessa área pouco definida entre a filosofia política e a sociologia (SILVA, 2008, p.30), afirmando-se como "departamento de ciência política" apenas em 1987. A falta de precisão na designação da Cadeira de Política serviria aqui como um indício do quanto o processo de afirmação dessa disciplina na universidade foi bem mais tortuoso.

\footnotetext{
${ }^{22}$ Assim foram criadas tanto a Cadeira de Antropologia a partir do desmembramento da Cadeira de Etnografia Brasileira e Língua Tupi-Guarani com Emílio Willems como catedrático, quanto a Cadeira de Política originada da Cadeira de Direito Político do curso com Paul Arbousse a sua frente (Silva, 2008, p.30).
} 
Já o posicionamento menos duro expresso nos balanços realizados sobre a antropologia com relação a São Paulo pode ser entendido, por sua vez, também como um indício de maior da consolidação dessa disciplina no país, pois desde as décadas anteriores, ela já contava com relativa tradição de pesquisas (tanto na USP como na ELSP), além de publicações próprias, como é o caso da Revista de Antropologia da USP ou mesmo a Revista do Museu Paulista, organizada por Herbert Baldus da ELSP desde 1947 (CORRÊA, 2003, 370). Não à toa, todos os balanços aqui levantados reconheceram a importância dos estudos paulistas desenvolvidos nos anos 1940-1950, ainda que identifiquem essa como uma fase marcada por certo amadorismo e pouca profissionalização na disciplina, ainda profundamente mesclada com a sociologia. A despeito dessas nuances é inegável que, para se legitimar, tanto cientistas políticos quanto antropólogos buscaram marcar diferenças e circunscrever espaços próprios de atuação em relação à sociologia paulista desenvolvida na Universidade de São Paulo, tomando essa disciplina como uma adversária nesse processo.

\section{O BIB e a especialização nas ciências sociais}

Por fim, cabe analisar um terceiro tipo de balanço disciplinar produzido no Brasil - os balanços bibliográficos - encontrado primordialmente no Boletim Informativo Bibliográfico (BIB). Por abranger temáticas da sociologia, ciência política e antropologia, esse conjunto de trabalhos é significativo, na medida em que aponta para o processo de especialização nas três áreas durante esse período. Com a sua primeira edição publicada em 1977, o BIB foi criado com o objetivo de "propiciar o desenvolvimento de uma infra-estrutura de documentação e pesquisa na área das ciências sociais" (BIB, Rio de Janeiro, $\mathrm{n}^{\circ}$ 1, p.5). Pensado, a princípio, como um órgão de divulgação do Grupo de Documentação em Ciências Sociais, o BIB era publicado como um suplemento da revista Dados, organizada pelo Iuperj. Em 1979, a Associação Nacional de Pós-Graduação em Ciências Sociais (ANPOCS) passou a se responsabilizar academicamente pela coordenação do boletim ${ }^{23}$.

\footnotetext{
${ }^{23}$ Quando foi fundada, a ANPOCS passou a centralizar diversas iniciativas que foram surgindo nos institutos de pós-graduação e pesquisa das ciências sociais. Além do BIB, organizado inicialmente pelo Iuperj, a Anpocs também voltou a republicar a Revista Brasileira de Ciências Sociais (RBCS) a partir de 1986.
} 
Criada em 1977 a partir do seu primeiro encontro promovido no Iuperj, a ANPOCS concretizou um dos experimentos mais emblemáticos das tarefas de "construção institucional" do período. Contribuindo para fixar a presença do Rio de Janeiro e de Minas Gerais como centros prestigiosos de produção de ciência social ao lado de São Paulo, a fundação da Anpocs difundiu a mentalidade profissional que serviu para a sua afirmação, dando a seus membros maior visibilidade no cenário nacional (KEINERT, 2011, p. 105). Trata-se de uma estratégia a fim de consolidar o grupo como representante do que seria o paradigma organizacional recém-surgido, ou seja, o formato da pós-graduação e a ideia da ênfase na pesquisa (Idem, ibidem). A publicação do BIB se inseriu no bojo dessas iniciativas, valorizando a especialização como marca de um ideal de profisssionalização e consolidação científica.

Para além dos informativos sobre eventos, pesquisas e defesas de tese divulgados na revista, o BIB tinha como o seu núcleo articulador, sobretudo, as resenhas bibliográficas elaboradas por diversos cientistas sociais brasileiros. Ao contrário dos textos estudados até agora, estes são balanços cujo mote é, fundamentalmente, sintetizar e apresentar os estudos realizados sobre determinada área de pesquisa, distanciando-se daquele objetivo inicial de interpretação do pensamento brasileiro e das ciências sociais que recentemente haviam surgido.

Apesar da grande variedade de temas explorados, a partir da análise das resenhas publicadas pelo periódico, nos defrontamos com algumas temáticas que tiveram grande repercussão nas ciências sociais e que apareceram com enorme destaque nas revistas especializadas publicadas pelos institutos de pesquisa e centros de pós-graduação criados no período ${ }^{24}$.

A primeira delas é o Estado brasileiro. Inaugurando a primeira resenha bibliográfica do BIB, o artigo escrito por Eli Diniz Serqueira e Renato Boschí, ambos pesquisadores do Iuperj na época, buscaram recuperar os estudos acerca desse tema, destacando o debate aberto entre Simon Schwartzman (Iuperj), Fabio Wanderley Reis (DCP da UFMG) e Fernando Henrique Cardoso (Cebrap) sobre as relações entre Estado e Sociedade. De todo modo, seja atribuindo maior autonomia para a dinâmica própria envolvida no Estado, seja entendendo Estado e Sociedade como elementos interconectados (BOSCHI; SERQUEIRA, 1977, p. 28), a análise do Estado brasileiro

\footnotetext{
${ }^{24}$ Para este capítulo, optou-se por uma abordagem sumária dessas questões. Nos capítulos sequentes desta dissertação, eles serão analisados em detalhe a partir dos artigos publicados nas revistas especializadas.
} 
mobilizou muitos cientistas sociais e esteve na dianteira do desenvolvimento da ciência política no país. Em realidade, foi a partir da ênfase científica estabelecida por esses intelectuais para a análise das instituições políticas que a ciência política começou a cunhar o seu espaço próprio de investigação, diferenciando-se da, então, predominante sociologia.

Aliado aos estudos sobre o Estado brasileiro também se desenvolveram diversos estudos na ciência política atentando-se para os partidos políticos, representação e processo eleitoral. Para entender o advento dessa linha de pesquisa é importante lembrar as suas conexões com a conjuntura autoritária brasileira, pois em um momento no qual os intelectuais buscaram intervir no debate público brasileiro, o problema da consolidação da democracia no país se colocava como uma prioridade a um só tempo intelectual e política (KEINERT, 2011, p.195). Na resenha bibliográfica escrita por Bolívar Lamounier e Maria D'Alva G. Kinzo, os autores destacaram o quanto este era um tema novo nas ciências sociais, dispondo de recente tradição de estudo (KINZO; LAMOUNIER, 1979, p.7). Fazendo um apanhado das pesquisas nesta área, os autores destacaram a utilização de métodos e técnicas de pesquisa inovadores no tratamento dos dados empíricos (Idem, p. 17) .

Já no campo da antropologia, os estudos sobre sociedades indígenas despontaram como uma das temáticas-chaves do processo de consolidação dessa disciplina no país. Como afirmou Eunice Durham em seu balanço sobre a pesquisa antropológica no país, se durante os anos 1940-50 o estudos das sociedades tradicionais, a imigração e a população negra dominavam as pesquisas na antropologia, a partir do golpe militar, os estudos sobre as sociedades indígenas adquiriram um novo impulso, sobretudo, a partir da criação do PPGAS do Museu Nacional (DURHAM, 1986, p. 162). Anthony Seeger e Eduardo Viveiros de Castro ratificaram essa posição em sua resenha, apontando as diversas frentes de investigação que foram se consolidando nesta linha pesquisa (Contato e mudança social, organização social, religião, etc.) (CASTRO; SEGEER, 1977, p. 11). Ainda que a antropologia não tenha se engajado em temas candentes da conjuntura nacional, ao contrário da ciência política (DURHAM, 1986, p.163), os autores sinalizaram, contudo, a forte atuação dos antropólogos no que diz respeito à situação indígena no país, criticando publicamente à política da FUNAI e formulando projetos que visassem atender às necessidades específicas das populações tribais (CASTRO; SEGEER, 1977, p. 22). 
Entretanto, apesar da grande visibilidade alcançada por esses objetos de investigação, os anos de 1964-1985 representaram também um momento de grande desenvolvimento e especialização nas disciplinas com a proliferação de temas cada vez mais diferenciados de investigação da realidade brasileira. Uma análise do boletim expressa com bastante nitidez esse crescimento, conforme a Tabela 1, que divide por temas as resenhas publicadas pelo boletim entre os anos 1977-1985 (edições 1-20).

Tabela 1 - A concentração de temas ${ }^{25}$

\begin{tabular}{|c|c|}
\hline Temas & Quantidade \\
\hline Sociologia e Antropologia urbana & 3 \\
\hline Sociologia do trabalho/movimento operário & 3 \\
\hline Sociologia das relações de gênero & 3 \\
\hline Estado & 2 \\
\hline História & 2 \\
\hline Análise do pensamento social brasileiro & 2 \\
\hline Sociologia da religião & 2 \\
\hline Teoria sociológica e metodologia & 1 \\
\hline Cultura popular & 1 \\
\hline Sociologia rural & 1 \\
\hline Sociologia rural & 1 \\
\hline Sociologia da educação & 1 \\
\hline Sociedade indígena & 1 \\
\hline Desigualdade e relações raciais & 1 \\
\hline Partidos políticos e formas de representação & 1 \\
\hline Outros & 1 \\
\hline TOTAL & 25 \\
\hline
\end{tabular}

Como é possível observar, apresentam-se, dentre as resenhas publicadas até 1985, ao menos quinze temáticas diferentes e, em geral, recentes na história das ciências sociais brasileiras, pois não se trata apenas da sociologia, da ciência política e da antropologia, mas da antropologia urbana, da sociologia da religião, do trabalho, do estudo sobre os movimentos sociais, processos eleitorais, regimes políticos, etc. $\mathrm{O}$ ímpeto inicial de se compreender o desenvolvimento histórico da sociedade brasileira

\footnotetext{
${ }^{25}$ Todas as tabelas nas quais se apresentam as divisões temáticas dentro das revistas (tabelas $1,8,9,10$ ) foram elaboradas a partir do título, as palavras-chave, e/ou o resumo e/ou a leitura do artigo.
} 
tendo em vista a interpretação do próprio processo de modernização no Brasil é superado progressivamente por novos objetos, mais específicos, voltados para aspectos variados da realidade social e política do país. Como afirmado anteriormente, trata-se do processo de especialização no interior dessas disciplinas a partir da afirmação de novos objetos de investigação, evidenciando, não apenas uma mudança das linhas de pesquisa, mas, sobretudo, uma ampliação do seu leque temático, indicando a consolidação das ciências sociais no país. No entanto, como será explorado nos capítulos a seguir, apesar da significativa ampliação das temáticas, em praticamente todos esses campos de pesquisa os autores dialogaram, em maior ou menos medida, com tema geral da democratização, o que aponta para a força da conjuntura brasileira no horizonte das investigações realizadas tanto na sociologia, quanto na antropologia e ciência política brasileiras.

Um segundo aspecto que merece destaque diz respeito aos próprios colaboradores do boletim (ver a Tabela 2). Expressando uma mudança de cenário nas ciências sociais brasileiras, o BIB tem a maioria das suas resenhas escritas por pesquisadores oriundos de alguns dos novos centros de pesquisa na área, como o IUPERJ, o CPDOC-FGV e o PPGAS do Museu Nacional. Essa nova distribuição se relacionou, por sua vez, com a expansão dos centros de pesquisa e dos programas de pós-graduação que passaram a se colocar no centro da produção na área das ciências sociais no país. Esse crescimento significativo dos institutos se expressa na própria proporção da sua colaboração no boletim, uma vez que eles representam 55,8\% das resenhas publicadas.

Tabela 2 - As Instituições

\begin{tabular}{cc} 
& (continua) \\
\hline Instituto/Universidade & Percentual (\%) \\
\hline IUPERJ & 30,3 \\
UNB & 16,3 \\
CPDOC-FGV & 11,6 \\
USP & 11,6 \\
Prog. Pós-graduação Museu Nacional & 9,3 \\
Unicamp & 4,7 \\
Fea-UFRJ & 4,7 \\
CEBRAP & 2,3 \\
\hline
\end{tabular}


Tabela 2 - As Instituições

\begin{tabular}{cc}
\hline & (conclusão) \\
\hline Instituto/Universidade & Percentual (\%) \\
\hline Idesp & 2,3 \\
Dep. Ciência Polit. UFMG & 2,3 \\
UFF & 2,3 \\
UFRGS & 2,3 \\
TOTAL & 100 \\
\hline
\end{tabular}

Ao lado da especialização e do crescimento da importância dos centros de pesquisa, essa breve análise do BIB nos permite evidenciar também o processo de expansão (e de maior equilíbrio) da produção das ciências sociais em outros estados, em contraposição à predominância paulista do período anterior. Isto, porque, divulgando as pesquisas mais recentes no Brasil, as resenhas publicadas contam com a colaboração de autores oriundos de diversos institutos e universidades (os artigos provenientes de instituições paulistas representam apenas 16,1\%). Como parte do projeto de expansão do ensino superior promovido pelo regime militar e com o apoio financeiro da Fundação Ford foram estes novos cursos e centros de pesquisa que elevaram o contingente de estudantes, docentes e pesquisadores nesta área por todo o país. As ciências sociais foram, portanto, ampliadas e a anterior hegemonia paulista dentro dessas disciplinas é também equilibrada com a produção carioca e mineira, principalmente através da fundação do IUPERJ, o curso de pós-graduação em Antropologia do Museu Nacional e o DCP na UFMG.

Por meio da análise dos diferentes balanços produzidos por cientistas sociais brasileiros, buscou-se, então, entender, mesmo que brevemente, algumas das mudanças mais significativas ocorridas na passagem do período de "fundação" para o da “expansão" das ciências sociais no Brasil, inaugurado a partir de 1964. Tratou-se aqui de introduzir, a partir de um conjunto de publicações específico produzido dentro das ciências sociais, o processo mais geral de consolidação desse campo de conhecimento, os grupos em formação, as suas disputas, assim como as transformações realizadas na 
própria estrutura do campo com os processos de fundação e expansão dessas disciplinas.

Com forte investimento no ensino superior, as ciências sociais foram profundamente beneficiadas, haja vista a ampliação dos cursos de graduação no país, assim como a criação e regulamentação dos programas de pós-graduação nas áreas de sociologia, ciência política e antropologia. Com uma oferta maior para a formação e especialização, o estreito nicho de produção e debate na área (centrado no eixo São Paulo (USP e ELSP) e Rio de Janeiro (ISEB)) foi adquirindo cada vez mais espaço no sistema nacional de educação. Ao contrário do vivenciado em países como a Argentina, onde o período da ditadura militar foi caracterizado pelo grande retrocesso no processo de institucionalização das ciências sociais, no Brasil, ao contrário, esse foi um momento de grandes oportunidades de crescimento e avanço na institucionalização da área (BLANCO; JACKSON, 2014, p. 64), apesar das políticas repressivas protagonizadas pelo Estado contra lideranças importantes da sociologia brasileira.

Um dos aspectos mais significativos desse período diz respeito à relação mais equilibrada que foi se estabelecendo entre a sociologia, a antropologia e a ciência política. Por isso, o capítulo que segue buscará avançar nessa caracterização, atentandose para as dinâmicas internas que foram se constituindo nessas duas últimas disciplinas em franca expansão. Para tal, será feito uso da análise das suas publicações especializadas, pois como parte desse novo momento de crescimento das ciências sociais, as revistas também se multiplicaram adquirindo uma feição cada vez mais científica e acadêmica. É com o intuito de analisar mais a fundo o processo de consolidação dessas disciplinas que será feito uso das suas publicações, entendendo-as como um lugar de observação privilegiado desse cenário inovador e dos debates e disputas que ali tiveram lugar. 


\section{CAPÍTULO 2 - OS INSTITUTOS DE PESQUISA E AS REVISTAS NA EXPANSÃO DAS CIÊNCIAS SOCIAIS}

Este capítulo investiga algumas das principais revistas criadas e publicadas durante o período de 1964-1985. De acordo com o primeiro capítulo, esse foi um momento de transformações e de clara expansão das ciências sociais no país. De um lado, foi aprovada a reforma universitária em 1968 que criou o sistema unificado de pósgraduação, elevou o número de vagas no ensino superior e modificou a organização das universidades, substituindo o regime de cátedras pelo departamental. Esse conjunto de medidas ampliou o acesso ao ensino superior e a oferta de postos de trabalho nas universidades. De outro, o financiamento estrangeiro patrocinou empreendimentos institucionais, permitindo a realização de pesquisas fora da universidade, o que - como veremos a seguir - foi fundamental nesse estágio de desenvolvimento das ciências sociais no Brasil.

Todas essas mudanças favoreceram o surgimento de novas publicações especializadas. Assim, com um contingente maior de estudantes, docentes e pesquisadores no país, as publicações de cunho mais acadêmico encontraram um ambiente extremamente propício para consolidação. Não à toa, foram criados nesse período coleções como Os Pensadores ${ }^{26}$ e Os Economistas $^{27}$ pela editora Abril que visavam publicar textos de autores clássicos europeus que ainda não dispunham de tradução no Brasil. Tais coleções foram fundamentais na tradução e divulgação de obras centrais do campo da filosofia e economia para o público universitário brasileiro.

Do mesmo modo, Sergio Buarque de Holanda criou a série História Geral da Civilização Brasileira (HGCB) em 1967 que contava com diversos artigos publicados por sociólogos, economistas e historiadores que buscavam refletir sobre a história brasileira desde diferentes perspectivas. A iniciativa fez parte dos esforços da editora Difusão Européia e de sua figura principal, Paul Monteil ${ }^{28}$, de publicação e difusão de obras como História Geral das Civilizações e História Geral das Ciências (CROUZET, 1955-1958; \& TATON 1959-1967) (VENÂNCIO; FURTADO, 2013, p. 13), que a

\footnotetext{
${ }^{26}$ Criada em 1973, a série Os Pensadores visava traduzir e divulgar no Brasil diversas obras de filósofos ocidentais.

${ }^{27}$ Iniciativa protagonizada pela mesma editora anos depois (1985) e que era voltada, por sua vez, para a publicação de obras de renomados economistas.

${ }^{28}$ Paul Monteil era um engenheiro francês, que vindo ao Brasil durante a segunda guerra criou não apenas a editora Difusão Européia, mas também a livraria francesa em 1947.
} 
editora havia traduzido e publicado anos antes. Com o objetivo de organizar um projeto de mesmo formato, mas voltado para a história brasileira, Sergio Buarque de Holanda encampou essa iniciativa juntamente com Boris Fausto (integrado posteriormente e responsável pela coordenação dos volumes relacionados ao Brasil Republicano).

A iniciativa de traduzir obras ou coletâneas renomadas e de realizar uma equivalente nacional relaciona-se com o expressivo crescimento da graduação e pósgraduação no país. A maioria dos intelectuais que colaboraram com a iniciativa possuía vínculos com institutos do ensino superior, desenvolvendo pesquisas no âmbito de suas especialidades $^{29}$ (Idem, p. 18) e continha a marca da USP na identificação institucional (62,12\% dos textos) (Idem, p. 15). Tal predominância não é aleatória, sobretudo, se for levada em consideração que o próprio Sergio Buarque de Holanda havia se tornado catedrático da Cadeira de História da Civilização Brasileira em 1960, criando em 1962 o Instituto de Estudos Brasileiros (IEB) na USP.

No âmbito das ciências sociais, foi lançada a coleção "Grandes Cientistas Sociais" publicada pela editora Ática e coordenada por Florestan Fernandes. Lançada em 1978, a série de livros visava destacar essa editora no mercado editorial brasileiro, no qual esse tipo de publicação ganhava destaque (BORELLI, 1996, p.106). Buscando resgatar, pensar e difundir as ciências sociais brasileiras, Florestan esteve à frente do projeto, o que indicaria o sucesso da sociologia preconizada pelo intelectual, a despeito do seu afastamento da universidade em 1969 por conta da ditadura. Novamente aqui, os intelectuais uspianos ganharam destaque na coletânea $(43,13 \%)^{30}$, ainda que a série tenha contado com a participação de pesquisadores de diferentes institutos (sobretudo paulistas) como a UNESP, UNICAMP, PUC-SP, etc.

A criação de novas revistas especializadas insere-se nesse cenário favorável às publicações de cunho acadêmico. Nas ciências sociais, observa-se o lançamento de periódicos especializados, principalmente, na ciência política e antropologia. O intuito principal desse capítulo é analisar revistas vinculadas a institutos de pesquisa e pósgraduação dessas áreas como a Revista de Antropologia da USP, publicada desde 1953,

\footnotetext{
${ }^{29}$ É importante, contudo, sublinhar a multiplicidade de áreas de conhecimento que participaram desse projeto, pois a HGCB escreveram não apenas historiadores, mas sociólogos, economistas, cientistas políticos, etc. (FAUSTO, 1988, p. 164), o que aponta para o constante intercâmbio dessas áreas em desenvolvimento.

${ }^{30}$ Foram analisadas as edições entre 1978-1985, por conta dos limites temporais estabelecidos pela pesquisa.
} 
a revista Dados organizada pelo Iuperj desde $1966^{31}$, a Estudos Cebrap publicada de 1971 até 1980 - quando foi reformulada passando a se chamar Novos Estudos Cebrap e a revista do DCP da UFMG publicada de 1974 até 1985. Tais periódicos formam um material empírico muito rico para o aprofundamento do estudo sobre o processo de consolidação das ciências sociais no Brasil e apontam para um aspecto central desse processo ao longo dos anos de 1964-1985: o crescimento e reconhecimento da antropologia e da ciência política como disciplinas independentes ao lado da sociologia brasileira.

\section{A expansão da antropologia e os seus periódicos: $O$ caso da Revista de Antropologia da USP}

Ainda que a antropologia tenha se expandido e legitimado no período em questão (1964-1985), tomando-se como parâmetro os seus periódicos é possível afirmar que, em comparação com a sociologia e a ciência política, os antropólogos ainda dispunham de poucos veículos especializados para divulgação de seus trabalhos. A sociologia foi a primeira das ciências sociais a publicar uma revista especializada, a revista Sociologia (da ELSP) e os sociólogos publicavam também em revistas culturais, como Anhembi e Brasiliense (JACKSON, 2004), o que expressava a centralidade dessa disciplina no período de fundação. A ciência política, como será analisada, foi firmando o seu espaço no cenário nacional organizando diversas publicações durante o período de 1964-1985, como a Dados, a Estudos Cebrap ou os Cadernos do DCP.

Já a antropologia quase não dispunha de periódicos especializados nesse período. Se tomarmos como exemplo o programa de Pós Graduação em Antropologia Social do Museu Nacional - maior iniciativa nesse campo - vemos que o mesmo começou a publicar uma revista própria (a Mana) somente na década de noventa. $\mathrm{O}$ departamento de pós-graduação em Antropologia Social da UNICAMP não dispunha nenhuma publicação própria no período, na UNB foi criada a Revista Séries Antropológicas em 1972, mas que contava com a colaboração quase que exclusiva dos seus próprios docentes e estudantes e, por fim, mesmo a Revista de Antropologia da USP, eleita para análise dentro desse capítulo, conta com uma publicação irregular,

\footnotetext{
${ }^{31}$ Para este estudo, nos centraremos na análise dos periódicos de 1966 até 1985, seguindo a faixa de tempo a ser explorada nessa pesquisa.
} 
ficando inativa por seis anos (1972-1978). Esse cenário nos ajuda a ponderar o processo de consolidação dessa disciplina, na medida em que aponta não apenas para os avanços, mas também para as dificuldades que ainda permeavam esse momento das ciências sociais brasileiras.

A Revista de Antropologia da USP constitui, desse modo, um bom ponto de partida para a análise da situação da disciplina durante esses anos, justamente por exemplificar bem não apenas o processo de expansão e amadurecimento dessa área de investigação, mas também suas dificuldades. O periódico surgiu em 1953 por iniciativa de Egon Schaden, até então catedrático da Cadeira de Antropologia. Sem quase nenhum apoio institucional e verba, a Revista de Antropologia da USP se manteve graças à iniciativa pessoal do antropólogo, seu editor por mais de vinte anos (CORRÊA, 2003, p. 373). Como afirma João Baptista Borges Pereira, o professor Egon Schaden financiou a revista com os próprios recursos durante muitos anos: "Costumo a chamar a Revista de "o periódico da abnegação" quando lembro de uma das raras confidências de Schaden: "Compro o papel, reescrevo os artigos, reviso as provas, envelopo e amarro os volumes, lambo os selo e levo nos ombros aos pouco para o Correio Central de São Paulo"” (PEREIRA, 1992, p. 11).

Disputando com a concorrente Revista do Museu Paulista ${ }^{32}$, a publicação contava com a colaboração majoritária de intelectuais estrangeiros, cabendo aos intelectuais brasileiros a participação, sobretudo, através das resenhas bibliográficas. Dentre as resenhas publicadas é importante destacar que as mesmas eram escritas não apenas pelos antropólogos da faculdade, mas principalmente pelos sociólogos da casa, evidenciando um cenário de pouca independência e força institucional da antropologia dentro da Universidade de São Paulo. Ao analisar a publicação nacional dentro da Revista de 1953 a 1964, Fernanda Peixoto e Júlio A. Simões reforçaram essa questão, na medida em que listaram os temas brasileiros - a sociedade rural tradicional, a imigração estrangeira, etc - ou ainda, as questões teóricas e metodológicas decorrentes dos "estudos de comunidade" e de "aculturação" como os principais objetos de debate tanto pelos sociólogos como pelos antropólogos que colaboravam na revista (PEIXOTO; SIMÕES, 2003, p. 370). Esse tipo de produção apontaria para um momento da história da antropologia, marcado pela sua estreita colaboração com a sociologia, na

\footnotetext{
${ }^{32}$ A Revista do Museu Paulista foi lançada em 1947 e dirigida por Herbet Baudus como uma releitura da Revista do Arquivo Municipal ligada ao Departamento de Cultura de São Paulo, dirigida por Mario de Andrade e Sergio Millet na década anterior (Jackson, 2004, p. 265).
} 
qual os pesquisadores não só compartilhavam temas e orientações teóricas, mas também "se deslocavam freqüentemente de uma disciplina para a outra" (DURHAM, 1982, p. 161).

A análise que se segue buscará acompanhar o desenvolvimento da Revista de Antropologia da USP durante o período posterior, de 1964 a 1985, no qual essa revista passou por uma série de transformações. Constituindo-se como a principal publicação da disciplina ao longo desses anos, com expressiva visibilidade nacional e tornando-se publicação oficial da ABA em 1958, esse periódico foi se especializando e se profissionalizando nesse período. O objetivo aqui é acompanhar esse processo, procurando entender, através dele, o desenvolvimento da própria antropologia no Brasil, aprofundando o estudo sobre os seus personagens, as suas temáticas e os debates que aí tiveram lugar.

Um das características da Revista de Antropologia da USP diz respeito aos seus colaboradores, recrutados em diversos lugares do Brasil, o que aponta para a expressiva visibilidade da mesma dentro da Antropologia. Contudo, é importante destacar que esse foi um processo lento, chegando a ganhar força apenas no fim da década de 1970 depois da retomada da Revista de Antropologia da USP. Antes disso, a situação era bem diferenciada. Circulando pouco e sem grandes recursos, a revista serviu muito mais de incubadora de textos etnológicos do que como sua depositária final (CORREA, 2003 p. 370).

Com circulação restrita e contando com pouca participação de autores nacionais, a revista acabou servindo inicialmente como um espaço de divulgação da etnologia alemã no Brasil. Analisando as publicações da revista de 1964 até 1968, antes do seu fechamento, é possível confirmar esse cenário. Abaixo, apresentamos uma tabela com a relação de autores que publicaram no periódico, exemplificando com clareza essa questão:

Tabela 3 - Os colaboradores da revista (1964-1985)

\begin{tabular}{cc} 
& (continua) \\
\hline Instituto/Universidade & Percentual (\%) \\
\hline Estrangeiros & $44 \%$ \\
Universidade de São Paulo & $18 \%$ \\
PPGAS Museu Nacional & $8 \%$ \\
\hline
\end{tabular}


Tabela 3 - Os colaboradores da revista (1964-1985)

\begin{tabular}{cc}
\hline Instituto/Universidade & (conclusão) \\
\hline Museu Paranaense "Emílio Goeldi" - BE & Percentual (\%) \\
UNB & $8 \%$ \\
PUC-CAMP & $6 \%$ \\
UFRGS & $2 \%$ \\
Museu Paulista & $2 \%$ \\
UFMT & $2 \%$ \\
ELSP & $2 \%$ \\
Instituto de Bothânica - SP & $2 \%$ \\
UFJF & $2 \%$ \\
USC & $2 \%$ \\
TOTAL & $2 \%$ \\
\hline
\end{tabular}

Como é possível observar, a contribuição estrangeira ainda ocupava um espaço significativo dentro da revista (quase metade dos artigos, sendo 59\% de autores alemães), o que pode ser entendido como um indicativo da própria situação do campo naquele momento, no qual a produção antropológica era ainda incipiente. Mesmo dentro da produção nacional vale lembrar que, dentre os artigos publicados pela Universidade de São Paulo (segunda maior colaboradora), parte significativa eram escritos pelo próprio Egon Shaden (33,33\%), o que evidencia a importância do seu empenho pessoal e o aspecto ainda pouco institucionalizado da revista na própria FFLC-USP.

Essa situação foi se modificando a partir do relançamento da revista em 1978. Depois de fechada por seis anos (1972-1978), em função de problemas no financiamento e organização, ela foi retomada no fim da década de 1970 como uma publicação oficial do Departamento de Ciências Sociais da Universidade de São Paulo 33. Com a saída do professor Egon Schaden da Universidade de São Paulo em $1967^{34}$ e formalmente da revista em 1978, o periódico foi assumido por João Baptista Borges Pereira e um conjunto restrito de jovens professores de antropologia recém ingressados

\footnotetext{
${ }^{33}$ Após a reforma universitária, as cátedras que organizavam o curso de ciências sociais são extintas com a criação de um único departamento para o curso de ciências sociais inteiro. Será apenas durante a década de 1980 que o mesmo se desmembrará nos departamentos de sociologia, antropologia e ciência política. Esse processo será retomado em detalhe no capítulo 3 .

${ }^{34} \mathrm{O}$ professor aposentou-se antecipadamente neste ano para reger a cátedra de Etnologia da Universidade de Bonn, na Alemanha, onde estivera várias vezes como professor visitante (Pereira, 1994, p. 251).
} 
na faculdade, como Thekla Hartmann, Renato Queiroz, Lux Vidal, Carlos Serrano, etc (PEREIRA, 2003. p. 320). Buscando manter a sua linha editorial, a revista foi aos poucos se expandindo e ampliando o diálogo com a antropologia que se desenvolvia nacionalmente.

Depois do seu relançamento em 1978, a Revista de Antropologia da USP foi ganhando mais força e visibilidade, constituindo-se, aos poucos, com um dos espaços de referência da disciplina no Brasil. Como veremos adiante, essa questão se expressou nas temáticas abordadas e nos debates instaurados, e pode ser dimensionada se analisada a mudança no perfil de colaboradores da revista.

Tabela 4 - Os colaboradores da revista (1978-1985)

\begin{tabular}{c|c|c|c}
\hline Instituto/Universidade & $\begin{array}{c}\text { Percentual } \\
\mathbf{( \% )}\end{array}$ & Instituto/Universidade & $\begin{array}{c}\text { Percentual } \\
\mathbf{( \% )}\end{array}$ \\
\hline Universidade de São Paulo & $32 \%$ & MAM - RJ & $3 \%$ \\
PPGAS Museu Nacional & $12 \%$ & UFRGN & $3 \%$ \\
UFBA & $11 \%$ & UFCE & $2 \%$ \\
Estrangeiros & $7 \%$ & UFMT & $2 \%$ \\
UNICAMP & $6 \%$ & PUCCAMP & $2 \%$ \\
Museu Paranaense "Emílio Goeldi” & $5 \%$ & UFRJ & $2 \%$ \\
- BE & & & $2 \%$ \\
UNB & $5 \%$ & Museu do Índio & $2 \%$ \\
UNESP & $5 \%$ & IUPERJ & $2 \%$ \\
UFPA & $3 \%$ & UFRGS & $2 \%$ \\
PUC-RJ & $3 \%$ & PUC-SP & $2 \%$ \\
UFPE & $3 \%$ & MUSEU PAULISTA & $\mathbf{1 0 0 \%}$ \\
\hline MAM - RJ & $3 \%$ & TOTAL & \\
\hline
\end{tabular}

De 1979-1985 a revista adquiriu, então, uma nova feição. A produção estrangeira, majoritária no período anterior, é reduzida a $7 \%$ e os autores nacionais tornaram-se majoritários. A participação da USP é grande (32\%) e diversificada com a multiplicação de intelectuais da casa que colaboraram com a revista. Do mesmo modo, é possível identificar o grande alcance geográfico da publicação, pois enquanto os periódicos ligados à ciência política contavam com artigos de intelectuais localizados quase que exclusivamente na região Sudeste, aqui foi possível verificar a participação 
expressiva de antropólogos de outras áreas do país, como o Nordeste (25\% dos autores são dessa região), o que sinaliza a expansão dessa disciplina no país durante esse período.

Assim como o leque de autores a escrever na revista foi aos poucos crescendo, a variedade de temas abordados no periódico foi se diversificando também. Como afirmou Mariza Corrêa em sua análise sobre os anos de 1953-1972, a etnologia dominava dentre os artigos da revistas: entre 150 artigos 86 deles eram voltados para os estudos etnológicos (CORRÊA, 2003, p. 371) o que expressaria o papel central e definidor dessa temática dentro da antropologia. Dentre esses, a grande maioria era produzida por autores estrangeiros, evidenciando a escassa produção nacional especializada da área de estudos ainda em formação (Idem, ibidem).

Com o processo de expansão dessa disciplina e a criação de novos programas de pós-graduação por todo país, essa situação foi se transformando e a antropologia passou não apenas a se concentrar em temáticas voltadas especificamente para a sua área, mas também a variar os seus objetos de estudo. Abaixo segue uma tabela das temáticas abordadas nos artigos na revista que ajudam a entender essa questão:

Tabela 5 - As temáticas da revista (1964-1985)

\begin{tabular}{cc}
\hline Temática & Percentual (\%) \\
\hline Etnologia Indígena & $34 \%$ \\
Religião e instituições religiosas & $17 \%$ \\
Antropologia da cultura e das formas expressivas & $22 \%$ \\
Antropologia africana & $8 \%$ \\
Antropologia de gênero & $2 \%$ \\
Antropologia e lingüística & $7 \%$ \\
Pensamento antropológico & $4 \%$ \\
Antropologia urbana & $5 \%$ \\
Antropologia rural & $1 \%$ \\
TOTAL & $100 \%$ \\
\hline
\end{tabular}

Como é possível observar, ampliaram-se os temas abordados dentro da revista, como a antropologia urbana, de gênero e da cultura, acompanhando o movimento de especialização e consolidação dessa área estudos no país. A Etnologia Indígena continuou a liderar as temáticas dentro da revista, ocupando um terço do seu espaço. 
Cabe destacar, contudo, que a contribuição brasileira nessa temática cresceu significativamente. Esse dado estaria associado ao crescimento da pesquisa e produção antropológica do período, elevando o número de pesquisadores na área dentro dessa disciplina. Uma das instituições mais importantes pela multiplicação de estudos dentro dessa temática foi o Programa de Pós-graduação em Antropologia Social do Museu Nacional. Tomando a etnologia indígena como uma das linhas de pesquisa centrais do instituto (CORRÊA, 1995, p.49), o Museu Nacional renovou os estudos dentro da área repensando perspectivas e conceitos acerca da etnologia.

Repensando a etnologia, o PPGAS do Museu Nacional foi adquirindo destaque e se firmando como o principal centro de pesquisa na antropologia do país. Como um programa de pós-graduação independente, no qual os seus docentes dedicavam-se exclusivamente às atividades de pesquisa, orientação e docência para a pós-graduação, sem a carga de aula e trabalhos que envolvem a graduação, o Museu Nacional conseguiu certa dianteira no cenário institucional, consolidando uma posição de destaque nesse campo em grandes transformações.

Um dos conceitos de maior destaque nessa direção foi a noção de contato interétnico formulada por Roberto Cardoso de Oliveira e expresso na Revista de Antropologia da USP em dois artigos: "O contato interétnico e os estudos de populações"35 e "O movimento dos conceitos na Antropologia"36. Empenhado em refletir a maneira como a antropologia tratava a relação entre as sociedades indígenas e a sociedade nacional, o autor definiu o contato interétnico como o "contato entre grupos tribais e segmentos da sociedade brasileira, caracterizados por seus aspectos competitivos e, no mais das vezes, conflituais" (OLIVEIRA, 1993, p.23). O objetivo em tal definição estaria, em primeiro lugar, na diferenciação do conceito de mudança cultural ou aculturação, utilizados nas ciências sociais durante as décadas de 1940 e 1950 - de inspiração norte-americana -, que, de acordo com o autor, tenderia a considerar os sistemas culturais em si mesmos, perdendo de vista, muitas vezes a população ou o grupo social portador (Idem, p.21). Distanciando-se dos estudos predominantes na antropologia paulista (PEIXOTO; SIMÕES, 2003, p. 391), Roberto Cardoso de Oliveira foi firmando a sua posição dentro da antropologia brasileira,

\footnotetext{
${ }^{35}$ OLIVEIRA, Roberto Cardoso. "O contato interétnico e os estudos de populações", in Revista de Antropologia da USP, vol. 17, pp. 31-48. São Paulo: Universidade de São Paulo, 1969.

${ }^{36}$ OLIVEIRA, Roberto Cardoso. "O movimento dos conceitos na Antropologia", in Revista de Antropologia da USP, vol. 35, pp.13-31. São Paulo: Universidade de São Paulo, 1969.
} 
colaborando para a renovação dos conceitos e problemáticas próprios da antropologia nos programas de pós-graduação (CORRÊA, 1995, p. 78).

Ao mesmo tempo, o conceito de contato interétnico significava um deslocamento do foco das relações de equilíbrio para as relações de conflito e o contexto dominador da dinâmica das fricções interétnicas. Trata-se, conforme indica o pesquisador, de apontar para a dimensão política das relações interétnicas, entendo as motivações econômicas que a conduzem (OLIVEIRA, 1969, p. 34). Esse verdadeiro combate à orientação de cunho mais "culturalista" foi uma marca desse novo período da antropologia, que buscava problematizar as relações entre a sociedade nacional e a sociedades tribais, valorizando o aspecto conflituoso desse contato (VELHO, 1980, p. 80). Esse foco na dimensão política que envolvia a situação indígena no Brasil, longe de constituir um aspecto isolado, insere-se como parte de uma tendência fortemente vivida dentro das ciências sociais de valorização do plano político nas pesquisas, o que se relacionou diretamente com a conjuntura autoritária no país.

Ao lado de artigos desse tipo, uma das apostas mais emblemáticas da Revista de Antropologia da USP relaciona-se à iniciativa constante de tornar esse espaço também uma fonte de divulgação e contato dos antropólogos nacionalmente. Assim, a revista dispunha de uma seção chamada "noticiários" na qual publicava sistematicamente as notas dos diferentes núcleos de pós-graduação do país, além de divulgar as próprias atas das reuniões da ABA, colaborando para a maior interlocução dentro da disciplina. Como afirmou João B Borges Pereira:

\footnotetext{
“a Revista noticiava, dava cobertura (...), era um canal de expressão. Esses antropólogos mandavam notícias para a Revista e nós as publicávamos, como as reuniões da $\mathrm{ABA}$, quem foi eleito representante da $\mathrm{ABA}$, cursos que estavam sendo ministrados pelo Brasil afora, colocando, enfim, em evidência os nomes das pessoas que atuavam na área. Era um meio de comunicação da comunidade acadêmica" (PEREIRA, 2003, p. 331).
}

O fato de caber à Revista de Antropologia da USP esse papel central de divulgação e articulação entre os pesquisadores da área no país (e não, por exemplo, do PPGAS do Museu Nacional que despontava como um dos institutos de maior destaque nacionalmente) pode ser entendido como uma estratégia por meio da qual os 
antropólogos uspianos buscaram reafirmar e manter a sua liderança dentro da disciplina, a despeito do crescimento significativo das pesquisas em outros centros e programas de pós-graduação do país. Projetando a sua revista nacionalmente, a antropologia uspiana se manteve em uma posição de destaque, divulgando os trabalhos dentro da área e todas as movimentações e realizações da ABA.

Criada oficialmente em 1955, a ABA iniciou seus trabalhos concentrada, sobretudo, no Rio de Janeiro com o apoio do Nordeste (DURHAM, 2003, p. 361). Significativamente, sua primeira diretoria foi formada por Luiz de Castro Faria, Darcy Ribeiro e Roberto Cardoso de Oliveira, todos intelectuais nucleados no Rio de Janeiro. Realizando reuniões a cada dois anos nas quais se elegia uma nova diretoria e se organizava os simpósios e as mesas redondas, a associação foi crescendo e ampliando a sua rede de interlocutores em todo país, seguindo o crescimento da própria antropologia.

Após o golpe militar, contudo, a organização das reuniões da ABA sofreu substantivamente. A $7^{\text {a }}$ reunião, programada para se realizar em 1965, na UNB, foi cancelada. A maioria dos cientistas brasileiros que estava colaborado com a criação da UNB havia pedido demissão ${ }^{37}$. A ABA conseguiu reunir-se apenas em 1966, em Belém, sob o guarda-chuva da Reunião Internacional sobre a Biota Amazônica. Nesse encontro, as mesas temáticas organizadas dialogaram todas com essa temática ${ }^{38}$, indicando a falta de força institucional e acadêmica da antropologia nesse momento. Já em 1971, Egon Schaden tentou organizar uma nova reunião da ABA na Universidade de São Paulo, por sua vez, dentro do I Encontro Internacional de Estudos Brasileiros. Essa reunião acabou se constituindo como uma iniciativa frustrada, pois contando com a participação de poucos antropólogos não pode ser eleita uma nova direção. Nesse quadro, a Revista de Antropologia da USP, empenhada na divulgação sistemática dos encontros da $\mathrm{ABA}$, não emitiu nenhum informativo acerca desta iniciativa (CORRÊA, 2003, p. 374).

A partir de 1975 as reuniões da ABA passaram a acontecer periodicamente a cada dois anos e as comunicações e mesas redondas foram ampliando e diversificando o seu leque temático. Em 1982, por exemplo, foram criados os GT’s temáticos dentro das

\footnotetext{
${ }^{37}$ Inclusive Eduardo Galvão, antropólogo dessa universidade, até então, presidente da ABA (Corrêa, 2003b, p.33).

${ }^{38}$ As comunicações apresentadas foram: "Arqueologia amazônica: Passado, presente e futuro"; "Estudos de Antropologia na Amazônia", "Comunidades amazônicas" e "Grupos lingüísticos na Amazônia" (REVISTA DE ANTROPOLOGIA, vol. 14, pp.131-132. São Paulo: Universidade de São Paulo, 1966).
} 
reuniões da $\mathrm{ABA}$, o que indicaria o alcance desse processo. Assim, nesse ano, foram realizados os GT's de: antropologia e o campesinato, antropologia e a mulher, antropologia urbana, antropologia e a família, ensino em antropologia, antropologia jurídica, antropologia e música, antropologia e o negro, antropologia e as religiões afrobrasileiras, sociedades indígenas e sociedade nacional e pesquisa lingüística e educação indígena (REVISTA DE ANTROPOLOGIA, 1983, p. 181-182).

No encontro realizado no ano anterior, em 1980, a ABA reformulou e aprovou um novo estatuto que, dentre outras coisas, oficializou a categoria de associados (aqueles que demonstrem interesse no estudo antropológico), o que permitiu a ampliação do número de associados à $\mathrm{ABA}$, sobretudo, dos jovens pós-graduandos que foram se formando no país ${ }^{39}$. Ao mesmo tempo foram criadas as seções regionais da ABA como a de São Paulo e a de Brasília, evidenciando a ampliação do espaço da disciplina que foi firmando-se como uma área de investigação autônoma dentro das ciências sociais.

Tal crescimento apareceu também quando analisamos a própria composição da diretoria da ABA. Analisando a tabela abaixo é possível ver o quanto essa situação foi se transformando ao longo dos anos:

Tabela 6 - A diretoria da ABA (1964-1985) ${ }^{40}$

\begin{tabular}{|c|c|c|}
\hline $\begin{array}{l}\text { Ano de } \\
\text { eleição }\end{array}$ & Diretoria eleita & $\begin{array}{l}\text { Período da } \\
\text { gestão }\end{array}$ \\
\hline 1966 & $\begin{array}{l}\text { Manuel Diegues Jr (PUC-RJ), Aryon Dall'Igna Rodrigues (na } \\
\text { época na UFRJ - RJ) e Roberto Augusto da Matta (Na época, } \\
\text { UFF- RJ). }\end{array}$ & $1966-1974$ \\
\hline 1971 & $\begin{array}{l}\text { Não houve eleição de uma nova diretoria, por falta de quorum } \\
\text { adequado. }\end{array}$ & \\
\hline
\end{tabular}

\footnotetext{
${ }^{39}$ Assim, foram criadas três categorias de sócios da ABA: A primeira - já existente - era a de membros efetivos. Para se tornar um membro efetivo, era preciso ser formado e atuar dentro da especialidade da antropologia e possuir uma obra notória no campo. O currículo era enviado para o conselho científico e aprovado em reunião. A segunda, de associados, era concedida aqueles que tivessem interesse pela área de antropologia. A terceira era a de sócio-correspondentes destinada aos antropólogos que atuavam fora do Brasil, mas que gostariam de integrar a associação (REVISTA DE ANTROPOLOGIA, vol. 24. São Paulo: Universidade de São Paulo, 1981, p 172).

${ }^{40}$ Associação Brasileira de Antropologia. Informações disponíveis em: http://www.portal.abant.org.br/index.php/institucional/features. Acesso em 15 de Janeiro de 2014.
} 
Tabela 6 - A diretoria da ABA (1964-1985)

\begin{tabular}{|c|c|c|}
\hline $\begin{array}{l}\text { Ano de } \\
\text { eleição }\end{array}$ & Diretoria eleita & $\begin{array}{l}\text { Período da } \\
\text { gestão }\end{array}$ \\
\hline $\begin{array}{c}12 \text { a } \\
14 / 12 / 1974\end{array}$ & $\begin{array}{l}\text { Thales de Azevedo (UFBA - BA), Yonne de Freitas Leite } \\
\text { (Museu Nacional - RJ) e Wagner Neves da Rocha (Museu } \\
\text { Nacional- RJ). }\end{array}$ & $1974-1976$ \\
\hline $\begin{array}{c}22 \text { a } \\
25 / 02 / 1976\end{array}$ & $\begin{array}{c}\text { René Ribeiro, Yonne de Freitas Leite (Museu Nacional - RJ) e } \\
\text { Wagner Neves da Rocha (Museu Nacional- RJ). }\end{array}$ & 1976-1978 \\
\hline $\begin{array}{c}07 \text { a } \\
09 / 05 / 1978\end{array}$ & $\begin{array}{l}\text { Luiz de Castro Faria (Museu Nacional - Rio de Janeiro), Yonne } \\
\text { de Freitas Leite (Museu Nacional - RJ) e Alba Zaluar } \\
\text { (Unicamp - SP). }\end{array}$ & 1978-1980 \\
\hline $\begin{array}{c}14 \text { a } \\
17 / 07 / 1980\end{array}$ & $\begin{array}{l}\text { Eunice Ribeiro Durham (Universidade de São Paulo), Antônio } \\
\text { Augusto Arantes (Unicamp - SP) e Peter Fry (Unicamp - SP). }\end{array}$ & 1980-1982 \\
\hline $04 / 1982$ & $\begin{array}{c}\text { Gilberto Cardoso Alves Velho (Museu Nacional-RJ), Roque de } \\
\text { Barros Laraia (Na época UNB-DF) e Rosilene B. Alvim } \\
\text { (UFRJ-RJ). }\end{array}$ & 1982-1984 \\
\hline $\begin{array}{c}15 \text { a } \\
18 / 04 / 1984\end{array}$ & $\begin{array}{l}\text { Roberto Cardoso de Oliveira (Na época, na UNB - DF), Pedro } \\
\text { Agostinho (UFBA - BA) e Marisa Veloso (UNB - DF). }\end{array}$ & 1984-1986 \\
\hline
\end{tabular}

Como é possível observar, o Rio de Janeiro esteve presente em quase todas as diretorias eleitas pela $\mathrm{ABA}$ ao longo desse período, muitas vezes contando com a presença de mais de um representante. Tal predominância aponta para a força do PPGAS do Museu Nacional, que contando com o apoio da Fundação Ford, esteve na dianteira do processo de formação de pesquisadores e renovação da disciplina nacionalmente. Todavia, ao longo da década de 1970 e 1980 essa situação foi se modificando e a diretoria passou a contar também com intelectuais de diferentes cidades brasileiras, como Brasília, Campinas, Bahia, etc - ainda que a predominância permaneça no Rio de Janeiro -; expressando o crescimento e consolidação da antropologia em outras localidades do país. O sucesso dessa iniciativa representou o fortalecimento dos laços associativos entre os antropólogos de diversas partes do país e uma redefinição dos seus espaços de debate e articulação através da construção de fóruns específicos de discussão e decisão em âmbito nacional. A ABA se formou como instituição fundamental no empenho dos antropólogos por uma posição autônoma ao lado da sociologia e da ciência política no interior das ciências sociais.

O estudo dessa revista permitiu delinear novos personagens, instituições de pesquisa e temáticas de investigação, o que aponta para a expressividade dessa 
publicação dentro da especialidade. É fundamental apontar também para a centralidade desse periódico para a própria Universidade São Paulo, pois articulando os pesquisadores nacionalmente, a antropologia uspiana continuou a manter uma posição de destaque nessa disciplina, a despeito do crescimento e expansão dos outros programas de pós-graduação no país durante esse período.

O PPGAS do Museu Nacional se destacou nesse estudo como uma das instituições fundamentais nesse processo. Com uma participação expressiva na colaboração de artigos na revista (ficando atrás somente da própria Universidade de São Paulo) e estando na dianteira dos debates acerca da etnologia brasileira e com forte participação nas reuniões e diretoria da ABA, esse instituto firmou uma posição de liderança e renovação na antropologia. Com o patrocínio da Fundação Ford, o programa conseguiu consolidar uma estrutura sólida para a formação e pesquisa dentro da especialidade, que até o momento detinha algumas poucas instituições que disponibilizavam a pós-graduação (sobretudo, a USP e a ELSP, ambas em São Paulo). Consolidando o seu espaço dentro das ciências sociais, ele foi protagonista no processo de desenvolvimento da antropologia brasileira com a inauguração de novos universos temáticos, referências teóricas e objetos de pesquisa.

Cabe destacar ainda a liderança de Roberto Cardoso de Oliveira nesse processo. Filho de um produtor de café, Oliveira graduou-se em Filosofia na USP, cursando o mestrado em sociologia sob a orientação de Florestan na década de 1960. Protagonizando a criação do PPGAS do Museu Nacional anos depois no Rio de Janeiro, o autor, no entanto, se desentendeu com a direção do Museu Nacional, demitindo-se da seção de antropologia (RUBIM, 1996, p. 99). Já em 1971, ele recebeu uma bolsa para o pós-doutorado na Universidade de Harvard e retornou ao Brasil no ano seguinte. A convite de Roque de Barros Laraia, ele integrou a equipe de pesquisadores que criou o programa de pós-graduação em antropologia nessa instituição, por fim, tornando-se docente da UNICAMP na década seguinte para participar da formação do programa de doutoramento em ciências sociais. Circulando em diferentes espaços, o antropólogo esteve à frente das principais iniciativas no processo de expansão da disciplina no país, constituindo-se como uma liderança central nesse processo.

À primeira vista, pode parecer no mínimo curioso um programa de tamanha força no cenário institucional não contar com a publicação de um periódico próprio na qual divulgue seus debates e trabalhos. Contudo, é importante não enrijecer a análise 
desse processo, tomando a publicação de periódicos como o único índice de sucesso na vida acadêmica, pois analisando a situação com mais cuidado é possível ver que embora essa não tenha sido a principal estratégia empreendida por esse instituto, os seus integrantes, em contrapartida, continuavam a produzir incansavelmente, sobretudo, através de livros e artigos em diferentes periódicos nacionais. Analisando o currículo de pesquisadores de peso no Museu Nacional como Roberto Cardoso de Almeida, Roberto da Matta e Otávio Velho, é possível observar que publicaram em praticamente todas as grandes revistas no período, sejam as mesmas especificamente de antropologia, sejam de fora dela ${ }^{41}$. Essa situação, já vista antes ${ }^{42}$, acabou favorecendo o PPGAS do Museu Nacional, pois mesmo sem editar uma revista, a presença de artigos em múltiplos espaços acabou trazendo mais visibilidade ao instituto e aos seus intelectuais, ajudando a sua afirmação dentro das ciências sociais.

Aliado a isso, a significativa publicação de livros acabou se configurando como mecanismo de divulgação bastante utilizado por esses intelectuais. Durante o período de 1964 e 1985, Roberto Cardoso de Oliveira, por exemplo, publicou 11 livros, seguido por Roberto da Matta (10 livros) e Otavio Velho (6 livros), ou seja, uma média de 1 livro sendo escrito a cada um ano, aproximadamente. Cabe por fim, lembrar a atuação desses intelectuais na ABA durante todo esse período. Participando ativamente de todos os encontros e reuniões esses três intelectuais fizeram parte da diretoria da Associação durante os anos de 1964-1985 ${ }^{43}$. Desse modo é que, mesmo sem editar uma revista própria do programa ao longo desses anos, o PPGAS do Museu Nacional buscou se fazer presente nas diversas instâncias de publicação e organização da disciplina, o que colaborou consideravelmente na consolidação e reconhecimento desse programa como uma liderança no interior da antropologia brasileira.

Assim como a ausência de um periódico próprio acabou por favorecer o PPGAS do Museu Nacional, na medida em que essa falta foi compensada com uma intervenção consistente e assídua com elevada publicação de livros, participações em outras revistas

\footnotetext{
${ }^{41}$ Encontram-se, assim, não apenas publicações desses intelectuais em periódicos voltados para a área Antropológica, como a Revista de Antropologia da USP, a Série Antropológica (Organizada pelo próprio Roberto C. de Oliveira, quando o mesmo migrou para a UNB), mas também em revistas como a Dados, a Estudos Cebrap, o BIB e em revistas de outras áreas de estudo como os Cadernos de Literatura da PUCRJ, a Revista de Administração Pública da FGV, etc.

${ }^{42}$ Luis Carlos Jackson identifica a mesma situação ao analisar a atuação do grupo conhecido como a "escola paulista de sociologia" durante a década de 1950. Ver, JACKSON, Luiz (2004).

${ }^{43}$ Roberto da Matta esteve na diretoria de 1966-1974, Gilberto Velho de 1982-184 e Roberto Cardoso de Oliveira de 1984-1986 (Associação Brasileira de Antropologia. Informações disponíveis em: http://www.portal.abant.org.br/index.php/institucional/features. Acesso em 15 de Janeiro de 2014).
} 
e na própria ABA, a manutenção da Revista de Antropologia da USP representou um trunfo fundamental para os antropólogos dessa instituição, pois articulando a divulgação das principais pesquisas e os noticiários e atas de reuniões nacionais, a USP conseguiu manter uma posição de destaque dentro dessa área apesar da proliferação de outros programas de pós-graduação de importância no cenário nacional. Aliado a isso, a relativa tradição de estudos nessa disciplina já existente em São Paulo (tanto na ELSP, quanto na Cadeira de Antropologia) foi fundamental para a manutenção dessa posição e o seu reconhecimento pelos pares. Como veremos no caso da ciência política, a maior fragilidade institucional dessa disciplina em São Paulo fez com que os institutos e programas de pós-graduação ignorassem quase que completamente a tradição de estudos políticos desenvolvidos na Universidade de São Paulo, criando seus próprios periódicos e buscando projetá-los nacionalmente.

\section{A autonomia do político em debate: Os institutos de pesquisa e as revistas} especializadas

A revista Dados surgiu em 1966 nos momentos iniciais de formação do Iuperj, quando este ainda não havia firmado o seu convênio com a Fundação Ford. Criada por Candido Mendes (editor da revista durante os seus 10 primeiros volumes), a Dados se consolidou como um dos empreendimentos mais bem sucedidos dentro dos periódicos das ciências sociais, até a atualidade. Com uma periodicidade regular (que começa anual e passa a ser trimestral no início da década de oitenta), a Dados ganhou grande visibilidade, contando com a colaboração de cientistas sociais dos principais institutos de pesquisa e universidades do país.

Logo no seu artigo de abertura, os seus organizadores trataram de reivindicar a renovação que o Iuperj representava no cenário das ciências sociais brasileiras. Valorizando experiências como as do ISEB, da Universidade de São Paulo e da CEPAL, a revista se dizia inspirada pelo Cadernos do Nosso Tempo (publicação organizada pelo ISEB na década de 1950-60), advertindo, no entanto, que “Guarda-se, daquela etapa, tão somente a mirada debruçada sobre o horizonte de processos largos de mudança decorrente do desenvolvimento", pois este novo empreendimento, por sua vez, buscaria se "dedicar ao esforço de rigorosa precisão no seu entendimento, utilizando técnicas e 
recursos propiciados pela rapidíssima evolução contemporânea das ciências sociais" (MENDES, 1966, p.10).

Sem negar a sua influência formadora, pois grande parte dos integrantes que fundaram o Iuperj haviam de algum modo trabalhado do ISEB $^{44}$, esse instituto buscou afirmar a sua especificidade através da valorização de uma abordagem pautada por critérios mais científicos e acadêmicos de investigação, em contraposição ao forte estreitamento da produção isebiana com a cena política. Como veremos adiante, seria a exigência de cientificidade o mote da crítica dos cientistas políticos do Iuperj aos sociólogos da USP, reivindicando a importância da pesquisa sistemática e do embasamento empírico como suportes da explicação científica (FORJAZ, 1997, p. 8). É curioso notar aqui a inversão do debate, pois se na década de setenta os intelectuais cariocas construíram a sua crítica a partir de um referencial cientifico de pesquisa nas ciências sociais, décadas atrás havia sido justamente em nome da sociologia como ciência que Florestan Fernandes embasou a sua crítica à sociologia carioca.

Em primeiro lugar, é importante analisar o fluxo de colaboradores em cada revista, começando pela Dados que contou com um grande número de autores de todo o país, além de diversos intelectuais estrangeiros, como demonstra a tabela abaixo:

Tabela 7 - Os colaboradores de cada revista

\begin{tabular}{cccc}
\hline Instituto/Universidade & Revista Dados & Estudos Cebrap & Cadernos DCP \\
\hline IUPERJ & $55,81 \%$ & - & - \\
Estrangeiros & $18,13 \%$ & $21,42 \%$ & $13,16 \%$ \\
FGV & $6,97 \%$ & $2,54 \%$ & - \\
USP & $5,58 \%$ & $13,95 \%$ & - \\
UFMG & $5,58 \%$ & $0,84 \%$ & $84,21 \%$ \\
CEBRAP & $3,72 \%$ & $34,75 \%$ & - \\
Unicamp & $3,25 \%$ & $10,16 \%$ & - \\
UFRGS & $3,25 \%$ & - & - \\
\hline
\end{tabular}

\footnotetext{
${ }^{44}$ Intelectuais como: Amaury de Souza, Carlos Estevão Martins, César Guimarães, Wanderley Guilherme dos Santos, além do próprio Candido Mendes.
} 
Tabela 7 - Os colaboradores de cada revista

\begin{tabular}{|c|c|c|c|}
\hline & & & (conclusãc \\
\hline Instituto/Universidade & Revista Dados & Estudos Cebrap & Cadernos DCP \\
\hline $\begin{array}{l}\text { Prog. Pós-graduação } \\
\text { Museu Nacional }\end{array}$ & $1,96 \%$ & - & - \\
\hline UFRJ & $2,79 \%$ & $0,84 \%$ & - \\
\hline UCAM & $1,39 \%$ & - & - \\
\hline PUC-RJ & $0,93 \%$ & $1,69 \%$ & - \\
\hline IDESP & $0,93 \%$ & - & - \\
\hline UNB & - & - & $2,63 \%$ \\
\hline OUTROS & $1,86 \%$ & $6,00 \%$ & - \\
\hline TOTAL & $100 \%$ & $100 \%$ & $100 \%$ \\
\hline
\end{tabular}

Como é possível observar, apesar da ampla maioria de autores serem integrantes do Iuperj, a Dados abriu diálogo com os centros mais importantes de produção na área das ciências sociais, como o Cebrap, a UFMG, a UNB, a USP, etc; o que evidencia não apenas a sua importância no pequeno mercado de revistas especializadas da área, mas também a repercussão nacional do próprio Iuperj, que se lançou como um forte concorrente à ocupar posição dominante antes centrada na Universidade de São Paulo em torno da "Escola Paulista de Sociologia"45.

Nesse processo, cabe sublinhar a importância do seu fundador, Candido Mendes, como figura fundamental na articulação institucional do Iuperj, assim como na negociação dos seus financiamentos, sobretudo, com a Fundação Ford (KEINERT, 2011, p.79). Oriundo de uma família bem relacionada com setores da Igreja católica e do poder público carioca, Candido Mendes participou ativamente da construção do ISEB em 1955, concomitantemente ao exercício do cargo de reitor da Universidade Candido Mendes criada pela família. Com o golpe militar e o fechamento do ISEB, ele mobilizou-se pela organização de um novo núcleo de produção acadêmica, o Iuperj.

\footnotetext{
${ }^{45}$ O lançamento do BIB (Boletim Informativo Bibliográfico) como suplemento da Dados em 1977 até 1979 pode ser entendido como parte dessa empreitada. Criado com o objetivo de "propiciar o desenvolvimento de uma infra-estrutura de documentação e pesquisa na área das ciências sociais" (BIB, Rio de Janeiro, $\mathrm{n}^{\mathrm{o}} 1$, p.5), o BIB se propunha catalisar tudo aquilo que havia de relevante nas ciências sociais brasileiras daquele momento. A organização de uma publicação dessas proporções pelo Iuperj nos dá muitos indícios das aspirações visadas pelo instituto no interior das ciências sociais brasileiras.
} 
Para essa nova empreitada, os contatos internacionais estabelecidos pelo autor em uma série de visitas à universidades prestigiosas dos Estados Unidos, assim como a sua rede de relações com os próprios militares, lhe renderam, respectivamente, os liames necessários para a assinatura do primeiro convênio da instituição carioca com a Fundação Ford em 1969 e a anuência necessária para a formação do instituto nessa conjuntura (Idem, p.81). Dispondo de amplos recursos financeiros e institucionais, o Iuperj conseguiu se lançar como uma iniciativa de peso dentro das ciências sociais brasileiras, adquirindo destaque nacional.

A revista Estudos Cebrap foi fundada dois anos depois da criação do instituto (1971) e foi pensada como uma publicação multidisciplinar que agregasse o conjunto de estudos produzido no Cebrap. Assim como no caso do Iuperj, foi graças ao círculo de relações estabelecidos pelo seu fundador, Fernando Henrique Cardoso, que o Cebrap pôde tomar forma e se consolidar como um dos centros de pesquisa mais importantes das ciências sociais.

Depois de ser afastado da Universidade de São Paulo, o jovem sociólogo foi para Santiago, integrando-se à Cepal (Comissão Econômica para a América Latina) e publicou em 1969 Dependência e desenvolvimento na América Latina em parceria com Enzo Faletto. Convidado para lecionar em Paris em 1967, FHC retornou ao Brasil em 1968, dispondo de grande circulação pela vida acadêmica estrangeira e gozando de significativo reconhecimento e prestígio internacional conquistados pela repercussão da sua teoria da dependência. Esta trajetória e o capital social e cultural acumulados pelo intelectual foram fundamentais na formação do Cebrap. Por um lado, permitiram ao sociólogo os contatos e visibilidade necessários na academia para a mobilização de um grupo de intelectuais competentes e dispostos a integrar esta iniciativa e, por outro, deram credibilidade à proposta em questão diante das negociações com a Fundação Ford.

FHC já havia conhecido alguns funcionários da agência quando esteve no Chile e procurou o representante da Fundação no Brasil, Peter Bell, para buscar financiamento (KEINERT, 2011, p.65). Contudo, ainda que fosse simpático à ideia, FHC era visto com desconfiança pelos representantes da Fundação, por ter sido aposentado compulsoriamente anos antes da USP. Porém, novamente aqui os contatos pessoais e a rede de relações do sociólogo foram chaves, pois, diante dessa incerteza, Fernando Henrique trouxe Paulo Egydio Martins e depois Severo Gomes para conversarem com 
Peter Bell. A estratégia empreendida foi explicitar o apoio de setores do establishment político dominante de modo a encorajar o financiamento da instituição estrangeira (Idem, p.66). O empréstimo dos nomes dos empresários Celso Lafer e José Mindlin ao conselho do Cebrap constituiu uma iniciativa de mesmo sentido.

Com a assinatura do convênio, o Cebrap foi se estruturando como um instituto de pesquisa multidisciplinar, incorporando em seu quadro de pesquisadores grande parte dos docentes afastados pela Universidade de São Paulo. Essa foi de imediato uma das características mais importantes na formação do centro, pois com o afastamento de parte do quadro docente dessa universidade, o Cebrap se constituiu, nesse contexto, como uma (ou em muitos casos a única) alternativa para quem havia sido afastado. Assim, no que diz respeito aos colaboradores da Estudos Cebrap, ela reuniu artigos, sobretudo, dos próprios integrantes do Cebrap e de instituições de pesquisa paulistas. Ao contrário da revista Dados do Iuperj que contava, comparativamente, com maior intercâmbio e participação de outros intelectuais do país, a Estudos Cebrap teve um círculo de colaboradores menor. Uma possível explicação para isso se relaciona com o fato da revista ser pensada pelos seus idealizadores menos como espaço de debate e combate com os outros institutos concorrentes na área e mais como uma prestação de contas para os financiadores e também para os agentes da repressão da ditadura, no qual se buscava reafirmar aquele empreendimento como um centro de pesquisas independente.

No entanto, se olharmos para os autores estrangeiros, a situação parece ser diversa. Ao longo de toda a coleção da revista (de 1971 até 1980) foi bastante assídua a contribuição de intelectuais europeus e norte-americanos na revista (36 artigos em 27 volumes publicados). Os europeus tiveram primazia (19 artigos diante dos 8 norteamericanos e 9 latino-americanos), o que se explica se levarmos em consideração a formação anterior europeia que os seus principais integrantes tiveram ${ }^{46}$. Do mesmo modo, a passagem dos principais organizadores do Iuperj pelos Estados Unidos parece ter influído também na situação bastante contrastante da revista Dados cuja colaboração estrangeira foi de mais de 70\% norte-americana. Certamente, essas diferenças de formação intelectual e de círculos de contatos na academia reapareceram, como veremos, nas interpretações dadas por cada um dos institutos à situação social e política brasileira.

\footnotetext{
${ }^{46}$ Fernando Henrique Cardoso, por exemplo, fundou o Cebrap após retornar da França onde lecionou durante alguns anos na Universidade de Nanterre. Já José Artur Giannotti esteve na França de 1956-58, freqüentando diferentes cursos na área de Filosofia.
} 
Por fim, a revista Cadernos do DCP surgiu posteriormente, somente em 1974 com os próprios recursos do departamento, financiado pela Fundação Ford. Ao contrário da revista Dados e da Estudos Cebrap, esse periódico teve um duração menor, sendo publicados apenas 7 edições, quando ele foi extinto em 1985. Do mesmo modo, enquanto as outras duas revistas tiveram uma ampla colaboração de outros institutos, os artigos do Cadernos DCP foram quase que completamente escritos pelos próprios integrantes do departamento $(84,21 \%)$, com destaque especial para Fabio Wanderley Reis que colaborou em praticamente todas as edições da revista, evidenciando o papel de liderança desse cientista político na consolidação do instituto de pesquisa.

Fabio Wanderley Reis se formou no curso de Sociologia e Política da FACE, realizando o seu mestrado na FLACSO-Chile conjuntamente com a geração de intelectuais mineiros, como Simon Schwartzman e Octavio Cintra, que após uma formação marcada pela forte competitividade e profissionalização acadêmica por conta do sistema de bolsas que selecionavam os melhores alunos do curso (ARRUDA, 1989, p. 258), realizaram o seu mestrado no exterior, tomando contato com a tradição da sociologia norte-americana ${ }^{47}$, o que se completou com o doutorado realizado anos depois nos Estados Unidos.

Assim é que com uma forte inspiração na sociologia e na ciência política americanas, esses autores buscaram construir uma nova tradição de estudos no Brasil. Com esse perfil, despontou o Departamento de Ciência Política da UFMG, que passou a atrair muitos jovens pela oportunidade de obter bolsas de estudo para formação no exterior. Fabio Wanderley Reis e Octávio Cintra lideraram essa iniciativa, coordenando os trabalhos e as disciplinas ministradas no departamento, fortemente marcada pela influência da sociologia norte-americana e os estudos em estatísticas, matemática e metodologia e técnicas de pesquisa (VEIGA, 1987, p. 24).

Contudo, com uma estrutura ainda frágil e limitada, sem conseguir dar abrigo institucional a muitos dos mineiros ali formados ${ }^{48}$, muitos deles emigraram para outras universidades e centros de pesquisa do país, como foi o caso do Iuperj, que recebeu intelectuais como Simon Schwartzman e Bolívar Lamounier na década de 1970. Esse

\footnotetext{
${ }^{47}$ Como lembrou Fabio Wanderley Reis, o mais importante, do ponto de vista profissional, da ida ao Chile foi: "o predomínio de orientação norte-americana, com grande atenção para a produção dos EUA e a preocupação com a articulação entre o trabalho teórico e a referência empírica" (REIS, 2004, p.21) ${ }^{48}$ Lembremos que o DCP foi o sexto instituto a receber as maiores dotações pela Fundação Ford, ficando atrás do Iuperj, do CEBRAP e do Museu Nacional, por exemplo. Enquanto o Cebrap chegou a receber U\$ 1.721.200, o DCP recebeu U\$ 860.477, cerca de 50\% a menos (Miceli, 1990, p.72).
} 
descompasso entre o DCP e os outros institutos reapareceu tanto do ponto de vista da quantidade e regularidade dos periódicos produzidos, como da expressão e visibilidade da revista nas ciências sociais, haja vista a menor participação de colaboradores provindos de outros institutos de pesquisa. Mesmo se nos atentarmos a colaboração estrangeira na revista, é possível observar uma menor participação deles na revista, cerca de $13,16 \%$, em contraposição aos $18,13 \%$ e $21,42 \%$ identificados na revista Dados e Estudos Cebrap, respectivamente. No entanto, a preponderância da influência norte-americana se fez presente assim como no caso do Iuperj, explicitando as proximidades teóricas e metodológicas entre os institutos, pois dentre os estrangeiros $80 \%$ eram norte-americanos.

Um primeiro olhar sobre as revistas permite delinear algumas das temáticas mais exploradas no período. Começando pela revista Dados, foi possível observar a proliferação de diferenciados objetos de pesquisa na área da ciência política:

Tabela 8 - As temáticas na revista Dados

\begin{tabular}{|c|c|c|}
\hline Temas & Quantidade & Porcentagem \\
\hline Desenvolvimento econômico e Economia & 36 & $15,30 \%$ \\
\hline Sistemas políticos & 21 & $8,90 \%$ \\
\hline Elites & 17 & $7,20 \%$ \\
\hline Educação, ciência e universidade & 19 & $8,10 \%$ \\
\hline Estado & 16 & $6,80 \%$ \\
\hline Teoria política e sociológica & 16 & $6,80 \%$ \\
\hline Relações de trabalho, classe trabalhadora e sindicatos & 15 & $6,40 \%$ \\
\hline Democracia & 11 & $4,66 \%$ \\
\hline Eleições & 9 & $3,81 \%$ \\
\hline Urbanização e estudos habitacionais & 9 & $3,81 \%$ \\
\hline Estratificação social & 8 & $3,40 \%$ \\
\hline Conjuntura Política & 8 & $3,40 \%$ \\
\hline Sociedades tradicionais, trabalho rural & 7 & $2,96 \%$ \\
\hline Violência & 7 & $2,96 \%$ \\
\hline Ideologias & 7 & $2,96 \%$ \\
\hline Partidos políticos & 5 & $2,11 \%$ \\
\hline Distribuição de renda & 5 & $2,11 \%$ \\
\hline Política Comparada & 5 & $2,11 \%$ \\
\hline
\end{tabular}


Tabela 8 - As temáticas na revista Dados

\begin{tabular}{ccc}
\hline Temas & Quantidade & (conclusão) \\
\hline Relações raciais & 4 & $1,69 \%$ \\
Cidadania & 3 & $1,27 \%$ \\
Religião & 1 & $0,39 \%$ \\
Outros & 7 & $2,96 \%$ \\
TOTAL & 236 & $100 \%$ \\
\hline
\end{tabular}

Dentro desse levantamento, foram identificadas mais de vinte temáticas diferentes, muitas delas inéditas, inaugurando novas frentes de investigação na ciência política brasileira, como é o caso dos estudos sobre a democracia, as eleições e a política comparada, por exemplo. Essa multiplicação de estudos dentro da ciência política é importante, na medida em que aponta para o adensamento do campo em constituição. Como veremos a seguir, na revista Estudos Cebrap é possível verificar esse mesmo processo em curso:

Tabela 9 - As temáticas na revista Estudos Cebrap

\begin{tabular}{ccc}
\hline Temas & Quantidade & Porcentagem \\
\hline Desenvolvimento econômico e Economia & 26 & $18,31 \%$ \\
Teoria política e sociológica & 18 & $12,17 \%$ \\
Relações de trabalho, classe trabalhadora e sindicatos & 14 & $9,86 \%$ \\
Estado & 13 & $9,15 \%$ \\
Agricultura, trabalho rural & 11 & $7,75 \%$ \\
Sistemas políticos & 8 & $5,63 \%$ \\
Urbanização e estudos habitacionais & 8 & $5,63 \%$ \\
Estudos demográficos e populacionais & 6 & $4,22 \%$ \\
Distribuição de renda & 6 & $4,22 \%$ \\
Educação, ciência, universidade & 5 & $3,52 \%$ \\
Crítica Literária & 4 & $2,40 \%$ \\
Elites & 4 & $2,40 \%$ \\
História & 4 & $2,81 \%$ \\
Estratificação social & 3 & $2,11 \%$ \\
Relações internacionais & 2 & $1,40 \%$ \\
\hline
\end{tabular}


Tabela 9 - As temáticas na revista Estudos Cebrap

\begin{tabular}{ccc}
\hline Temas & Quantidade & Porcentagem \\
\hline Ideologia & 2 & $1,40 \%$ \\
Religião & 2 & $1,40 \%$ \\
Mulher & 2 & $1,40 \%$ \\
Partidos Políticos & 1 & $0,70 \%$ \\
Violência & 1 & $0,70 \%$ \\
Democracia & 1 & $0,70 \%$ \\
Outros & 3 & $2,11 \%$ \\
TOTAL & $\mathbf{1 4 2}$ & $\mathbf{1 0 0 \%}$ \\
\hline
\end{tabular}

Assim como a revista Dados, os artigos da Estudos Cebrap trouxeram diferentes temáticas e algumas delas bastantes recentes nas ciências sociais brasileiras. Contudo, ao contrário da concorrente carioca, as áreas de investigação foram mais amplas, destacando-se alguns temas que foram para além para própria ciência política, como análises demográficas e estudos populacionais, os estudos urbanos, artigos sobre a sociologia da religião e estratificação social, trabalhadores e movimento operário.

Essa dimensão multifacetada da produção do Cebrap se relaciona com as próprias condições de fundação do centro. Isto, porque ele foi lançado buscando confluir diferentes disciplinas tais como a sociologia, ciência política, filosofia, economia, etc. Em um cenário de controle sobre o ensino e a produção universitária, o Cebrap constituiu-se como uma alternativa para pesquisadores em diferentes áreas do saber que encontraram ali um espaço de trabalho e produção intelectual. Do contato direto entre especialidades distintas é que novos campos de pesquisa foram se formando, como é o caso, por exemplo, da sociologia urbana que ganhou força a partir da publicação coletiva do livro São Paulo 1975: crescimento e pobreza, no qual se analisou as condições de vida em São Paulo, identificando que o desenvolvimento econômico ao invés de reduzir, na verdade aumentou a pobreza na metrópole.

O tema do desenvolvimento econômico apareceu como majoritário em ambas as publicações. Tendo sido um objeto de estudo clássico na sociologia na década de 1950 e 1960, ele não deixou, no entanto, de ter o seu espaço garantido dentro das ciências sociais, ainda que tenha passado por profundas transformações. Como apontado por 
Keinert, a partir de meados da década de sessenta, o processo de modernização e industrialização brasileiro passou a ser investigado pelos cientistas sociais em correlação direta com o regime político no Brasil, entendendo o fenômeno do autoritarismo, não no registro da excepcionalidade, mas como um fenômeno recorrente e atuante na história brasileira (KEINERT, 2011, 191). Assim, os nexos entre o desenvolvimento econômico e a ditadura emergiram nesse contexto como um dos problemas centrais da ciência política brasileira (Idem, p. 180), o que é indicado pelo volumoso número de artigos com essa temática. Essa acabou sendo uma tendência expressa nas diferentes linhas temáticas nas ciências sociais, pois ao mesmo tempo em que se verifica um processo de especialização e de multiplicação de objetos de pesquisa, em todos esses trabalhos existe também uma preocupação comum de problematizar o regime militar brasileiro e a maneira como este vinha lidando com questões como às dos índios, da cidade, dos camponeses e das sociedades rurais, dos trabalhadores industriais, etc.

Logo nos primeiros números da revista Estudos Cebrap, por exemplo, Fernando Henrique buscou refletir sobre a conjuntura brasileira com o artigo $O$ regime político no Brasil, no qual o sociólogo paulista interpretou o golpe de 1964, se diferenciando, por um lado, das análises que sobrevalorizaram o peso das estruturas econômicas no andamento da vida política do país, entendendo o Estado como mero executor dos interesses de classe, tal como as análises de Celso Furtado acerca do golpe (CARDOSO, 1971, p.91), e por outro lado, das interpretações que atribuíram um peso exagerado ao plano político, entendendo os debates entre os atores com um enredo puramente ideológico e alheio à base social e política, como expresso nas reflexões de Candido Mendes acerca deste tema (Idem, p.111).

Para o autor, o investigador deveria entender essas instâncias de maneira combinada, investigando as forças sociais que atuaram de modo decisivo e foram valorizadas pelas políticas adotadas durante o golpe, ao mesmo tempo em que se analisa o mecanismo de poder que tornou viável tal formação institucional, pois ainda que exista uma relação clara entre economia e sociedade, é evidente que existem diferentes caminhos políticos para se chegar a um determinado padrão de desenvolvimento, cabendo ao analista, portanto, compreendê-los (Idem, p. 91). Assim, Fernando Henrique avaliou a conjuntura inaugurada, defendendo que o período militar seria marcado por um modelo de desenvolvimento econômico amparado na noção de livre empresa em 
contraposição à orientação favorável ao estatismo econômico, atribuída pelo governo anterior (Idem, p.86). Nesse cenário, perderiam prestígio e poder os setores tradicionais e agrários da economia, ganhando espaço os setores vinculados ao capitalismo internacional, através da associação direta ou indireta das empresas brasileiras com as estrangeiras (Idem, p. 89).

O regime político em curso teria cumprido um papel importante nesse processo, na medida em que atuou de modo a conter a mobilização dos setores populares, desmantelando as organizações sindicais e políticas que pressionavam o poder público por melhorias sociais substantivas (Idem, p. 90). A desarticulação desses setores seria entendida pelo sociólogo como uma medida de urgência para a garantia do processo de acumulação chave para o sucesso desse empreendimento. Nesse sentido, Fernando Henrique continuou a refletir sobre o desenvolvimento brasileiro, atinando, contudo, à importância do jogo político nesse processo. As dimensões políticas e econômicas ficariam, assim, cada vez mais entrelaçadas, evidenciando centralidade da política (e do Estado) como um problema para as ciências sociais brasileiras do período.

Já na revista Cadernos DCP foram escassos os estudos sobre a economia e o desenvolvimento brasileiro se compararmos com a grande quantidade de artigos publicados nas outras duas revistas dentro dessa temática. Todavia, foi possível identificar, apesar das poucas edições publicadas, a proliferação de novos objetos de pesquisa centrados principalmente na ciência política brasileira:

Tabela 10 - As temáticas na revista Cadernos DCP

\begin{tabular}{ccc}
\hline Temas & Quantidade & Porcentagem \\
\hline Sistemas Políticos & 5 & $15,16 \%$ \\
Políticas Públicas & 4 & $12,12 \%$ \\
Sociedades tradicionais, trabalho rural & 4 & $12,12 \%$ \\
Abertura Política & 3 & $9,09 \%$ \\
Partidos políticos & 3 & $9,09 \%$ \\
Estado & 3 & $9,09 \%$ \\
Política comparada & 3 & $9,09 \%$ \\
Economia & 3 & $9,09 \%$ \\
Pensamento Social Brasileiro & 2 & $6,06 \%$ \\
Estudos urbanos e habitacionais & 1 & $3,03 \%$ \\
\hline
\end{tabular}


Tabela 10 - As temáticas na revista Cadernos DCP

\begin{tabular}{ccc} 
& & (conclusão) \\
\hline Temas & Quantidade & Porcentagem \\
\hline Elites & 1 & $3,03 \%$ \\
Sociologia da cultura & 1 & $3,03 \%$ \\
TOTAL & $\mathbf{3 3}$ & $\mathbf{1 0 0 \%}$ \\
\hline
\end{tabular}

De maneira geral, comparando as três revistas, é possível afirmar que as temáticas exploradas foram semelhantes. Cabe, nessa análise comparativa, apenas sublinhar a importância dos estudos urbanos e populacionais no Cebrap (essa última temática foi inexistente nas outras), assim como a grande quantidade de artigos sobre a situação da classe operária, frente de pesquisa de grande força nesse instituto, a partir das pesquisas impulsionadas, sobretudo, por Francisco Weffort e Francisco de Oliveira. Do mesmo modo, na revista Dados e na Cadernos DCP verifica-se maior volume para temáticas como sistemas políticos, partidos políticos e democracia, o que se relaciona com a proposta tanto do Iuperj quanto do DCP-UFMG de se constituírem como programas de pós-graduação especializados na área de ciência política no Brasil.

Contudo, apesar das diferenças, em todos os periódicos estudados, temas como sistemas políticos, partidos e o Estado apareceram entre as principais questões abordadas pelas publicações. Este é um ponto importante, na medida em que revela o crescimento substantivo das instituições políticas e dos embaraços para a consolidação democrática no país como objetos de investigação centrais entre os cientistas sociais brasileiros. Como explorado por Forjaz, a autonomia das formas político-institucionais se constituíram como uma ambição da ciência política daquele momento. Originária da conjuntura autoritária e dos desafios postos a esses intelectuais diante da abertura política, a importância atribuída a essas questões esteve no centro do processo de consolidação da ciência política (FORJAZ, 1997, p.5).

O tema das instituições políticas apareceu, então, como elemento fundamental no processo de diferenciação e de busca por legitimidade da ciência política. Bastante influenciada pela tradição norte-americana, a ciência política brasileira buscou demarcar a especificidade do seu campo diante, sobretudo, da sociologia, assumindo como princípio a autonomia do sistema político e das suas formas. A partir dessa exigência é que se multiplicaram os estudos sobre o Estado, regimes políticos, as eleições, etc; 
lançando mão de novas técnicas de pesquisa e tratamento de dados para dar conta dessas questões.

É importante apontar que o surgimento de estudos com esse tipo de temática não pode ser entendida sem levar em conta o momento político brasileiro, pois em uma conjuntura marcada pela forte interferência do Estado e das forças políticas na vida social brasileira, o olhar dos pesquisadores para essas instâncias passou a se colocar como uma das principais questões na agenda nacional. Desse modo, muitos dos artigos publicados nos periódicos foram nessa direção, buscando responder aos eventos políticos brasileiros, amparados sempre pela cientificidade e o profissionalismo ao explorar estas questões.

Desse modo é que em uma conjuntura autoritária a ênfase dos estudos nas ciências sociais foi aos poucos se deslocando em direção aos impasses para a consolidação democrática no país. Dentro da ciência política foram se multiplicando as análises acerca da dimensão formal do sistema democrático (como eleições, partidos políticos, formas de governo), na medida em que a transição se aproximava. Esse conjunto de estudos nos quais se buscou avaliar e discutir as possibilidades de implementação do regime democrático no país se relaciona com esse novo momento na intelectualidade brasileira marcado pelo forte engajamento no debate público, no qual esses cientistas, apesar das orientações políticas e teóricas distintas, tinham em comum a condição de opositores do regime (KEINERT, 2011, p.94).

No fim dos anos 1970, por exemplo, o Cebrap passou a atuar mais diretamente na política e no jogo partidário vigente no país. Estreitando relações com o MDB, a ponto de participarem da formulação do programa de campanha do MDB para as eleições de 1974, Fernando Henrique, Bolívar Lamounier, Vilmar Faria, Luiz Werneck Vianna participaram ativamente deste processo, sendo Fernando Henrique candidato ao senado pelo MDB em 1978. Além disso, é preciso destacar o engajamento em interpretar o significado do êxito eleitoral do MDB, esforço levado a cabo com a publicação do livro Os Partidos e as eleições no Brasil, em 1975, sob a coordenação de Lamounier e Cardoso, alcançando considerável repercussão pública.

É importante lembrar que a atuação dos cientistas sociais nos partidos brasileiros foi relativamente nova na história das ciências sociais brasileiras (Idem, p.95), sobretudo, em São Paulo, onde certa distância entre a academia e a vida partidária havia predominado (MICELI, 1989, p. 71). A atuação do Cebrap nesse caso indica com 
clareza uma mudança geracional (KEINERT, 2011, 93), na qual o engajamento na vida pública com um viés de oposição ao regime e favorável à democracia, a despeito das múltiplas posições políticas em jogo, foi se constituindo como uma das características centrais desses novos cientistas políticos brasileiros (Idem, ibidem).

Nesse cenário, as instituições do sistema político brasileiro se firmaram como objetos de investigação favoritos dessa intelectualidade, ocupando o lugar anteriormente ocupado pelos temas do desenvolvimento econômico e da modernização, que mobilizara toda a geração de cientistas sociais durante a década de $1950^{49}$. Essa mudança na hierarquia de objetos não deixou de trazer consigo grandes polêmicas, nas quais os cientistas políticos - mesmo que aliados na defesa da autonomia das esferas políticas - divergiram quanto ao grau de autonomia conferida as mesmas na análise científica e a importância de articulá-las com outras instâncias da sociedade. A edição especial da revista Dados sobre as eleições de 1976 trouxe com toda a força essa questão, colocando em debate algumas das figuras-chave da ciência política brasileira.

No especial preparado para a edição 14 da revista Dados foi aberta uma discussão acerca das eleições de 1976, recuperando o debate aberto sobre as eleições de 1974 entre Simon Schwartzman (Iuperj), Fabio Wanderley Reis (do DCP da UFMG) e Fernando Henrique Cardoso (Cebrap). Abarcando figuras intelectuais protagonistas do processo de criação da ciência política no país, os textos acabaram por se centrar na relação entre Estado e Sociedade, explicitando algumas das diferenças a esse respeito que marcaram esses institutos.

A principal controvérsia teórica diz respeito à maneira de equacionar a relação entre Estado e Sociedade na análise política. Schwartzman deu abertura ao debate, defendendo que a análise do desenvolvimento político brasileiro deveria ser pensada, antes de tudo, a partir da antinomia cooptação/representação cuja relevância ou preponderância na nossa história seria, em primeiro lugar, uma questão empírica (SCHWARTZMAN, 1977, p.164). Desse modo, o autor fez uma reconstrução histórica da nossa vida política, chegando à conclusão que no Brasil os mecanismos de cooptação tiveram uma força muito maior na articulação do sistema político brasileiro. O Estado brasileiro teria, assim, fortes traços de um Estado patrimonial, no qual os grupos

\footnotetext{
${ }^{49}$ Sobre as relações entre a sociologia e o processo de modernização brasileiro, ver: BOTELHO, André (Org.); BASTOS, E. R. (Org.); VILLAS BOAS, G. (Org.). O moderno em questão. A década de 1950 no Brasil. $1^{\text {a }}$. ed. Rio de Janeiro: Topbooks/CAPES/PPGSA-UFRJ, 2008. 411p.
} 
políticos atuantes estiveram bem mais preocupados em ter acesso às posições de poder e prestígio em um regime político centralizado do que em garantir a representação de seus interesses na esfera burocrática e administrativa (Idem, p.176). O autor pontuou ainda que refletir sobre o poder público brasileiro a partir da noção de classes e da representação de seus interesses estaria distante do horizonte brasileiro, na medida em que não existiriam ainda grupos sociais autônomos capazes de formular os seus interesses de maneira específica de modo a canalizá-los para o aparato estatal (Idem, p.181).

Essa tese foi bastante criticada e é objeto de intensa discussão na revista. Tanto Fabio Wanderley Reis como Fernando Henrique Cardoso convergiram no rechaço à dicotomia Estado e Sociedade, mobilizada por Schwartzman. Para esses autores, tais perspectivas deveriam ser incorporadas de modo integrado na análise, levando em conta a coexistência de elementos aparentemente antitéticos atuando de modo decisivo na conjuntura em questão. Fernando Henrique vai ainda mais longe: atribuindo a Simon a pretensão de construir explicações totalizantes, estas implicariam modelos vazios de conteúdo, caracterizando o Estado como se as classes, movimentos sociais e a economia não existissem (CARDOSO, 1977, p. 202).

Assim, ainda que tenham atuado conjuntamente na construção da autonomia das instâncias políticas e na valorização das formas político-institucionais, esses autores divergiram quanto à forma de articular analiticamente essas dimensões com outras instâncias da sociedade. A ênfase exagerada nas variáveis político-institucionais se tornou, então, objeto de discussão entre esses intelectuais. Fabio Wanderley Reis criticou a polarização construída por Schwartzman a entendendo como, em certa medida, essencialista, por não explicitar as condições da sociedade que viabilizaram e que explicam as feições próprias da atuação do Estado ao longo da história, a não ser a partir de proposições abstratas e demasiado generalizadas (REIS, 1977, p. 195). As relações entre Estado e Sociedade deveriam ser trabalhadas pelo investigador em termos concretos, buscando avaliar a cada momento as tensões e coalizões formadas nesse processo (Idem, p. 192).

Fabio Wanderley Reis reafirmou essa mesma crítica posteriormente ao analisar as teses de doutoramento de três cientistas políticos professores do Iuperj (SOUZA, 1976; SANTOS, 1979; LIMA JR., 1980): 
"Os trabalhos de Souza, Lima Jr. e Santos têm em comum o fato de privilegiarem, como se disse, o plano institucional. De maneira mais ou menos reiterada, essa abordagem é também formulada, por todos eles, em termos de se dar a ênfase apropriada aos fatores ou variáveis políticos na explicação da história brasileira recente, por contraposição à dimensão estrutural, aos processos sociais, socioeconômicos, sociopsicológicos, etc... Parece apropriado indicar aqui, contudo, o que teria havido de falta total de clareza e consequentemente de abuso relativamente à ideia de "autonomia do político"“، (REIS, 1985, pp. 108-109 e 113).

Desse modo, ainda que tenham buscado conjuntamente legitimar o estudo das instituições políticas como um campo de investigação próprio, esses grupos concorrentes na ciência política brasileira não deixaram de se diferenciar e o debate em torno do excesso de valorização das formas político-institucionais se constituiu como uma das frentes centrais nesse processo.

Fernando Henrique Cardoso, por sua vez, atinou para a mesma questão de Fabio Wanderley Reis quando afirmou parecer difícil discutir o tema da cooptação e da representação sem ir mais fundo na organização do Estado e na sua relação com a sociedade, tal como ela se apresenta em um tipo específico de sistema socioeconômico (CARDOSO, 1977, p. 204). Para o intelectual, seria essencial construir uma análise global, relacionando as diferenças e oposições entre sociedade, Estado e economia, sem dissolvê-las na síntese (Idem, p. 201). A crítica à polarização Estado/Sociedade foi combinada aqui com a defesa da perspectiva marxista desenvolvida - mesmo que de maneira velada no texto - a partir da valorização da articulação dialética entre as diferentes esferas da vida social. Essa é uma questão cara à Cardoso, visto que ele foi um dos personagens fundamentais na incorporação dessa perspectiva nas ciências sociais com o "Seminário do Capital" organizados na década de 1960.

A incorporação da teoria marxista como referência central de análise para a vida social e política brasileira foi reivindicada nesse debate e rebatida por Simon Schwartzman que qualificou a visão de Fernando Henrique como uma posição ortodoxamente classista, explicando a política pelo confronto entre grupos e classes, seguindo os moldes marxistas mais convencionais, o que não daria lugar à reflexão acerca das problemáticas próprias do Estado e da política brasileira (SCHWARTZMAN, 1977, p. 169). Esse é um ponto importante, pois como lembrou 
Forjaz, o marxismo se consolidou como um importante paradigma teórico nas ciências sociais brasileiras durante as décadas de 1960 e 70, sendo, contudo, o alvo de crítica principal dos cientistas políticos mineiros e cariocas no processo de consolidação da disciplina no Brasil (FORJAZ, 1997, p.14). Como será abordado adiante, o marxismo esteve em debate na ciência política brasileira, dividindo grupos em disputa em busca de legitimação e hegemonia.

De acordo com Keinert, o impacto do marxismo na geração pós-1968 foi intenso nas universidades, consolidando esta corrente como um paradigma teórico e político enraizado numa conjuntura de intensa polarização ideológica (KEINERT, 2011, p. 151). Emblema maior da posição esquerdista no meio intelectual, a senha de acesso às ciências sociais implicava o domínio dos ensinamentos de Marx e seus continuadores, como Georg Lukács, Louis Althusser e Nicolas Poulantzas (Idem, ibidem). A influência dessa perspectiva de análise ganhou força em função do momento de intensa mobilização e politização dentro e fora das universidades na década de 1960 (Idem, p.149). Na sociologia paulista, cabe lembrar ainda a criação dos "Seminários de Marx", organizados por Fernando Henrique Cardoso e José Arthur Giannotti e que reuniu durante anos jovens professores das Ciências Sociais, História, Filosofia e Economia com o objetivo de reler e estudar a literatura marxista para refletir sobre o desenvolvimento da sociedade brasileira.

De fato, o marxismo fortaleceu-se como uma vertente teórica influente no Cebrap, apesar das enormes diferenças existentes no grupo. Como lembra Fernando Henrique: "O clima intelectual era de bastante controvérsia e briga intelectual (...). Fazíamos um seminário em um "mesão", em que discutíamos os trabalhos que eram discutidos na casa ou por pessoas amigas" (CARDOSO, 2009, p.39). Também sobre o famoso "mesão", Giannotti afirma: "Em geral todos os projetos passavam pelas discussões do mesão. Nossa tradição francesa, e depois, nossa familiaridade com os seminários americanos nos ensinaram a discutir até o último fôlego" (Giannotti, 2009, p.58). Esse clima de calorosos debates ganhou espaço na revista Estudos Cebrap, na qual os seus próprios participantes escreveram e criticaram as posições de seus colegas de trabalho ${ }^{50}$. Novamente aqui a liderança de Fernando Henrique na intermediação e

\footnotetext{
${ }^{50}$ No primeiro volume da revista Estudos Cebrap, os artigos centrais correspondiam ao debate caloroso entre Fernando Henrique e Francisco C. Weffort, ambos integrantes do Cebrap, acerca da "teoria da dependência" criada pelo primeiro.Enquanto Weffort criticava FHC por não levar em conta a dinâmica de classes de cada país ao atribuir grande importância às relações internacionais de dependência entre as
} 
condução dos debates é apontada pelos seus participantes como um dos elementoschave na conciliação das diferentes posições em jogo ${ }^{51}$.

Desse modo é que, apesar das diferenças, o marxismo foi se constituindo como um dos elos centrais de articulação do grupo ${ }^{52}$. Mesmo ao longo da revista Estudos Cebrap, a referência marxista se fez presente, não apenas como base de reflexão acerca do Brasil que se desenvolvia (tanto no campo da economia, como na história, nos estudos sobre o movimento operário e sindical, etc), mas também como objeto de estudo em textos de cunho teórico e filosófico ${ }^{53}$ e nisso a revista se diferenciou bastante de outras como a Dados do Iuperj e os Cadernos do DCP do DCP da UFMG, nas quais o marxismo foi visto com grande suspeita e alvo de duras críticas.

Tal desconfiança foi combinada também com a tendência crescente nas ciências sociais de explicar o desenvolvimento histórico-social brasileiro a partir de categorias econômicas, que acabaram redundando em muitos casos num reducionismo economicista no qual não havia espaço para a se pensar a política como uma dimensão própria da realidade social (FORJAZ, 1997, p. 9). A geração de cientistas políticos empenhada na legitimação dessa disciplina no quadro das ciências sociais brasileiras se defrontou com esse quadro de referências, criticando a falta de cientificidade dos trabalhos desenvolvidos sob esta perspectiva e reivindicando a autonomia do político nas análises propostas.

Essa polêmica ganhou forma em diferentes artigos publicados por esses institutos. Wanderley Guilherme dos Santos, por exemplo, foi enfático nessa direção ao discutir a situação da ciência política na América Latina, na revista Dados. Entendendo o economicismo como uma das principais deficiências nas análises políticas no continente, o autor afirmou que essa espécie de mecanicismo, no qual os fenômenos políticos são traduzidos como meros reflexos dos processos econômicos, sem explicitar

nações (WEFFORT, 1971, p.10); FHC diz que falta à Weffort entender estes processos a como uma unidade dialética a partir da qual os fatores externos e internos se entrecruzam (CARDOSO, 1971, p.30).

51 "A atuação de Fernando Henrique no Cebrap, nos anos 1970, foi muito importante. Ele escutava os argumentos dos outros, mesmo que fossem diferentes dos dele, abria espaço para que o argumento se desenvolvesse, compreendia, entendia a alteridade"( KOWARICK, Lucio, 2009, p.135).

${ }^{52}$ Como afirma Lúcio Kowarick; "Houve um lado positivo no Cebrap. Primeiro: reunia pessoas diferentes do ponto de vista intelectual, com trajetórias e perspectivas diversa. E o que unia esse grupo? A opção dos que foram aposentados de permanecer no Brasil e uma afinidade intelectual cujo denominador comum talvez fosse o marxismo" (KOWARICK, 2009, 135).

${ }^{53}$ Entre vários, podemos citar, por exemplo: "Estado Capitalista e o marxismo" (CARDOSO, vol. 21); "O Ardil do trabalho" (GIANNOTTI,1973), "As origens do sindicalismo populista no Brasil" (WEFFORT, Francisco C.,1973); "O terciário e a divisão social do trabalho" (OLIVEIRA, Francisco, vol.24); "Conflito social na República Oligárquica: A greve de 1917" (BORIS, Fausto, vol. 10). 
a conexão entre as partes em questão (SANTOS, 1980, p. 23). Esse "marxismo de segunda classe", como nomeado pelo autor, produziria um amontoado de volumes com uma qualidade de pesquisa lastimável (Idem, p. 25). Trata-se aqui de uma série de estudos nos quais o zelo conceitual dispensaria maior apuro de investigação científica das relações em questão (Idem, ibdem).

Simon Schwartzman incorporou a mesma crítica, evidenciando a formação de um discurso comum acerca da tradição de interpretação dos fenômenos políticos nas ciências sociais. Considerando a atividade política como epifenômeno da realidade econômica das relações de produção, a perspectiva marxista entenderia a política como algo sem vida e determinação própria, indigna de ser vista e estudada em si mesma (SCHWARTZMAN, 1969, p.24). Desse modo, os problemas vinculados ao desenvolvimento político seriam negligenciados, o que em uma conjuntura autoritária traria sérios problemas para a análise da realidade social. A defesa empreendida pelo autor foi a de tratar os fenômenos políticos como algo dotado de uma realidade própria, buscando entender as suas formas e mecanismos de articulação próprios (Idem, p.52).

De qualquer modo, estava em jogo nesses embates a disputa pelos cientistas políticos por um espaço de legitimidade ao lado dos sociólogos em um contexto de redefinição de posições nas ciências sociais brasileiras. A crítica ao paradigma marxista se proporia, nessa direção, a validar a especificidade e autonomia dos objetos de pesquisa próprios da ciência política, deixando de entendê-los como mero reflexo da vida social e econômica e passando a concebê-los como instâncias que tem uma dinâmica própria de funcionamento e exigem, do mesmo modo, o estudo apurado por parte dos cientistas.

Essas mesmas questões foram abordadas por Fabio Wanderley Reis no artigo "A propósito da ciência e dialética", publicado em $1966^{54}$. Nele o autor começa identificando nos intelectuais formados na Faculdade de Filosofia, Ciências e Letras (FFCL) da Universidade de São Paulo os principais representantes da corrente marxista de trabalho sociológico (REIS, 1966, p. 298). Assim, o autor tomou como ponto de partida o artigo escrito por Giannotti meses antes ${ }^{55}$ para defender o estabelecimento de um compromisso sério dos cientistas políticos com os padrões de análise dos fenômenos

\footnotetext{
${ }^{54}$ Reis, Fabio Wanderley. "A propósito da ciência e dialética", in Revista Brasileira de Ciências Sociais, UFMG, vol.4.

${ }_{55}^{5}$ Giannotti, Arthur (1965). "A propósito de uma incursão na dialética”, in Revista Civilização Brasileira, vol. 3, São Paulo, Editora Civilização Brasileira, pp. 101-109.
} 
sociais e não apenas com a reiteração indefinida de princípios gerais (Idem, p. 303). Para o intelectual mineiro, seria preciso superar essa resistência à assimilação e ao emprego criterioso de métodos e técnicas no tratamento dos dados, deixando de concebê-los como um mero estorvo nas construções analíticas dos estudos de cunho totalizante (Idem, p. 304). Assim, Reis criticou os trabalhos de Fernando Henrique e Francisco Weffort ${ }^{56}$, na medida em que ambos deixaram muito a desejar na abordagem e manipulação dos dados colhidos em suas respectivas pesquisas ${ }^{57}$.

Desse modo, foram se desenhando os grupos em disputa na ciência política brasileira e o marxismo acabou se configurando como divisor de águas. Aqui tanto os cariocas como os mineiros estiveram na dianteira desse processo, buscando ganhar espaço frente a São Paulo, até então, predominante nas ciências sociais brasileiras. Não à toa foram escolhidos os trabalhos de Fernando Henrique e Francisco Weffort como representantes dessa "sociologia ainda iniciante" na abordagem dos dados empíricos (REIS, 1966, p.308).

Outro aspecto fundamental nessa direção diz respeito à importância da experiência desses cientistas políticos nos Estados Unidos. Esse é um ponto que une as trajetórias de Simon Schwartzman, Fabio Wanderley Reis e Wanderley Guilherme dos Santos, que fizeram as suas teses de doutorado nos Estados Unidos a partir das bolsas concedidas para pesquisarem no exterior. Tal experiência partilhada foi importante, pois foi nos EUA que esses jovens autores tiveram contato com um campo no qual a ciência política estava mais consolidada, tendo estabelecido linhas de investigação específicas desse campo - como eleições, governo, partidos, comportamento eleitoral, instituições políticas -, marcado pela forte valorização do trabalho empírico e a utilização de inovadoras técnicas e metodologias de pesquisa e tratamento de dados quantitativos.

Foi ali que esses intelectuais foram treinados, retornando para o Brasil fortemente impactados com a formação recebida e dispostos a construir uma nova tradição de estudos no país. A incorporação dessa cultura científica acabou forjando certa coesão a esse núcleo de pesquisadores que acabaram identificando-se entre si com

\footnotetext{
${ }^{56}$ Fabio W. Reis refere-se a esses dois trabalhos: Cardoso Fernando Henrique (1964), "Empresário Industrial e Desenvolvimento Econômico no Brasil”. São Paulo, Difusão Européia do Livro e Weffort, Francisco C. "Raízes Sociais do populismo em São Paulo", Revista Civilização Brasileira, vol. 2, 1965, pp. 39-60.

${ }^{57}$ Como afirmou Fabio W. Reis: "Recém chegados ao Brasil e transformados numa espécie de "jovens turcos" de uma ciência social mais consistente e rigorosa, nós [Antônio O. Cintra, Simon Schwartzman e o próprio Fabio Reis] compramos a briga da Metodologia (...) com o establishment sociológico da época, especialmente os paulistas..." (REIS, 2004. p. 23).
} 
base em um ethos acadêmico específico (Keinert, 2011, p. 162) e bastante distante das diretrizes mais gerais do marxismo. Essas questões acabaram atuando de modo decisivo na construção da ciência política brasileira e na defesa da autonomia relativa das esferas políticas que deixariam de ser explicadas como mero produto das condições sócioeconômicas.

\section{Cebrap, Iuperj e DCP - UFMG postos em perspectiva}

Talvez seja interessante aproveitar o desfecho deste capítulo para traçar algumas comparações entre o Cebrap, o Iuperj e o DCP da UFMG, pois ao colocá-los em perspectiva torna-se possível contextualizar e entender estes empreendimentos desde uma visada mais ampla. Uma primeira questão que chama atenção e ganhou expressão nos periódicos diz respeito ao próprio objetivo que se propôs cada instituto.

Enquanto o Cebrap foi fundado como um centro de pesquisas independente e multidisciplinar, o Iuperj e o DCP da UFMG foram lançados como Programas de PósGraduação em Ciência Política, primeiros do país na área. A proposta diferenciada reapareceu nas próprias revistas, pois enquanto na Dados e no Cadernos do DCP as temáticas relacionadas a este campo de pesquisa adquiriram grande expressão nas obras e também nos periódicos lançados por este instituto (tais como Estado, regimes políticos, partidos políticos e sistemas eleitorais), na Estudos Cebrap vimos como as temáticas nesta publicação são mais equilibradas, aglutinando estudos nas áreas de Sociologia, Ciência Política, Economia, História, Demografia e Filosofia ${ }^{58}$.

Evidentemente, o peso da sociologia em São Paulo, e de maneira mais geral, da própria USP (MICELI, 1989b, p.70) contribuiu para tal configuração em São Paulo. Com certa vantagem na institucionalização do ensino superior paulista, o Cebrap pode se constituir agregando toda essa geração de pesquisadores competentes e formados em diferentes áreas, mas, sobretudo, da Universidade de São Paulo, possibilitando o encontro de distintos campos de conhecimento em um único centro de pesquisa. Essa

\footnotetext{
${ }^{58}$ A temática das eleições começou a ser objeto de investigação no Cebrap somente em meados da década de setenta, com a chegada, fundamental nesse processo, do mineiro e ex-pesquisador do Iuperj, Bolívar Lamounier. Como afirmou Fernando Henrique: " O Cebrap ainda estava mais na visão "classe e partido" do que "partidos e eleições", e eu apoiei o Bolívar e disse " Nós vamos ter que estudar isso, porque temos que nos preparar para uma estrutura que não vai ser a do caminho que se imaginava possível há vinte anos: O jogo vai se dar num outro tabuleiro" (Cardoso, 2009, p. 36)
} 
pluralidade acabou atuando de maneira bastante favorável para este instituto, pois impulsionou a formação de novas especialidades nas ciências sociais - como já abordado -, assim como permitiu ao Cebrap intervenção do grupo em diferentes frentes de debate abertos na academia, ampliando a visibilidade do Cebrap e o colocando na dianteira de muitos dos centros de pesquisa do país ${ }^{59}$.

Sob outra perspectiva, a condição do Iuperj e do Departamento de Ciência Política da UFMG de Programas de Pós-Graduação em Ciência Política trouxe a esses institutos preocupações maiores com a cientificidade e produtividade de seus integrantes. Com forte inspiração norte-americana, os seus integrantes estiveram profundamente empenhados na consolidação de novos objetos de pesquisa, cada vez mais específicos, que caberiam à ciência política investigar, ao mesmo em que estiveram atentos às metodologias de pesquisas empregadas e a comprovação empírica das hipóteses levantadas pelo investigador.

Esse é um ponto importante, pois esteve no centro do debate acerca da consolidação da ciência política no país. A questão era, por um lado, se diferenciar da sociologia brasileira, desenhando um conjunto bem específico de objetos de investigação para essa disciplina, para a qual a autonomia, mesmo que relativa, do sistema político foi se constituindo como uma doxa fundamental para os praticantes da disciplina. Por outro, tratava-se também de se diferenciar com o mero discurso militante tão frequente em um momento de grande mobilização no país e legitimar a posição da ciência política como ciência. Para isso, a utilização de métodos e técnicas de pesquisa passou a ser introduzida de modo sistemático nos estudos produzidos pela Ciência Política no país, com forte influência do repertório norte-americano. Como afirmou Octávio Cintra ainda em 1966 "Em qualquer parte do mundo em que ela [ciência empírica] se efetiva, deverá tender para o ideal de um saber de forma empíricodedutivo. Deverá ter como critério último de aceitação de seus resultados a experiência ou refutá-los de modo controlável e comunicável (CINTRA, 1966, p.5).

De tal maneira, a ciência política foi se legitimando no Brasil como uma disciplina autônoma e como ciência ao lado da sociologia e da antropologia. Esse processo, no entanto, não deixou de envolver disputas e debates entre diferentes grupos em busca de hegemonia no campo em formação. Os periódicos organizados pelos

\footnotetext{
${ }^{59}$ O Iuperj, em contraposição, busca ampliar os seus horizontes criando o Programa de Pós-Graduação em Sociologia apenas no fim da década de 1970.
} 
próprios institutos de pesquisa se constituíram, então, como espaços de divulgação, mas também de confrontos, importantes nos quais as diferentes posições foram sendo demarcadas e debatidas por esses intelectuais.

Entretanto, a despeito das diferenças, é importante destacar o papel dessas revistas no processo de reorganização das ciências sociais e consolidação da ciência política durante a década de 1970. Isso, porque em uma conjuntura na qual se combinou a repressão e o controle da produção intelectual com um grande investimento e expansão das ciências sociais, esses periódicos cumpriram um papel fundamental na divulgação dos trabalhos que foram sendo realizados dentro da área e na articulação desses intelectuais abrindo o diálogo para que se confrontassem diferentes perspectivas de estudo em constante disputa. De todas as revistas analisadas, a Dados foi a que mais se empenhou nessa direção. Com um significativo número de colaboradores por todo o país, essa revista adquiriu uma circulação importante dentro das ciências sociais brasileiras, protagonizando importantes debates com os centros de pesquisa mais importantes das ciências sociais no período.

O estudo desses periódicos se apresentou, portanto, como uma via de acesso fundamental para o estudo da institucionalização desse conjunto de disciplinas, as “ciências sociais". Não apenas pela sua expressividade, pois através desse estudo foi possível apontar algumas das temáticas e questões em debate nessa área de estudos, mas também por se configurar como um espaço de defesa aberta da constituição da disciplina como campo de estudo autônomo, dotado de objetos e metodologias próprias de análise. É através, portanto, também destes espaços que a institucionalização da disciplina vai se realizando no Brasil e o estudo desses periódicos visa apreender justamente a dinâmica específica desse processo.

O estudo apresentado acima buscou, por meio da análise de algumas publicações, explorar o processo de expansão das ciências sociais brasileiras e de consolidação, sobretudo, da ciência política e da antropologia no país. Como acima analisado, os praticantes dessas disciplinas vivenciaram um dinâmico processo de renovação e afirmação dentro do quadro mais amplo das ciências sociais. No entanto, 
em cada uma dessas disciplinas, observamos uma relação diferenciada com a tradição paulista de investigações: enquanto na ciência política desconsidera-se completamente a tradição de estudos realizados dentro da Cadeira de Política da Universidade de São Paulo - a despeito dos esforços de Paula Biguelman e seu grupo - colocando-se em uma posição de liderança e de protagonismo no desenvolvimento dessa disciplina; na antropologia esse processo de afirmação se deu por meio de um diálogo muito mais aberto com a antropologia paulista, o que se expressa seja na atuação conjunta dentro da ABA, seja com a participação ativa dentro da Revista de Antropologia da USP, por exemplo.

Nesse processo, os institutos de pesquisa e programas de pós-graduação se firmaram como espaços protagonistas na formação de intelectuais, no desenho do universo temático de investigação, nas referências teóricas incorporadas, etc. Dotados de certa independência com relação às universidades e com o patrocínio da Fundação Ford, esses centros adquiriram certa vantagem dentro das ciências sociais, podendo contar com uma estrutura de amparo à pesquisa, sem os encargos de aulas da graduação, o que possibilitou expandir as suas atividades, se fortalecendo no cenário institucional. As revistas analisadas expressaram justamente essa nova configuração nas ciências sociais, na qual os centros se destacaram seja patrocinando as publicações, seja participando ativamente delas. Assim, foi possível identificar alguns debates em voga no momento, como a questão do Estado, das instituições políticas ou mesma da etnologia indígena, no caso da antropologia, o que apontaria para uma maior autonomização dessas disciplinas dentro das ciências sociais, pois se na década de 1950-1960 os debates travados convergiam para a sociologia, em torno das possibilidades de "desenvolvimento nacional"; no período seguinte foram surgindo novos campos de investigação, por sua vez, cada vez mais variados e especializados, seja dentro da antropologia, seja dentro da ciência política apesar de buscarem dialogar sempre com uma preocupação comum, o regime ditatorial brasileiro.

É importante destacar também que como parte do processo de consolidação das disciplinas e profissionalização dos seus trabalhos, os próprios periódicos foram se transformando. Se anteriormente as revistas eram centradas na figura de seu editor, com fortes traços pessoais na sua organização e publicação, ao longo dos anos elas foram adquirindo um caráter cada vez mais institucional. Assim, a Revista de Antropologia da USP foi aos poucos deixando de ser uma publicação centrada na figura do seu 
catedrático, Egon Schaden, passando a ser organizada por um conselho editorial depois da sua saída formal da revista em 1978, acontecendo o mesmo com a Dados e Candido Mendes e a Estudos Cebrap e Fernando Henrique Cardoso ${ }^{60}$. Esse processo de profissionalização das revistas pode ser percebido na própria estrutura das publicações. Com o passar dos anos, os artigos que antes tinham 30, 40 páginas foram sendo substituídos por uma variedade maior de textos mais curtos, cada vez de acordo com o padrão de revistas científicas internacionais. A revista Dados, por exemplo, foi completamente reformulada a partir de 1980 e a Estudos Cebrap em 1981 passou a se chamar Novos Estudos Cebrap, adquirindo um novo formato, tal como é conhecido hoje.

No capítulo que segue, buscaremos aprofundar o estudo acerca da relação entre essas disciplinas, com os olhares voltados, dessa vez, para a situação da sociologia na Universidade São Paulo durante esse período. O objetivo agora é entender como essa instituição reagiu às transformações em curso dentro das ciências sociais brasileiras com o afastamento de importantes lideranças acadêmicas com as aposentadorias compulsórias, a reforma universitária e o crescimento significativo dos institutos de pesquisa e cursos de pós-graduação por todo o país. Esse é um movimento importante, na medida em que ajuda a dar maior unidade ao estudo proposto, balanceando a análise dos novos empreendimentos que foram se consolidando com as renovações e transformações pelas quais as antigas instituições de ensino foram submetidas.

\footnotetext{
${ }^{60} \mathrm{O}$ mesmo não se deu com o Cadernos DCP por conta da sua pouca regularidade e duração (1974 até 1985).
} 


\section{CAPÍTULO 3 - ENTREATO: A SOCIOLOGIA DA USP E A DITADURA MILITAR}

Uma apreensão detida da fase de expansão das ciências sociais brasileiras não poderia deixar de lado um exame das circunstâncias que levaram à reorganização do ensino e da pesquisa na Universidade de São Paulo em função das aposentadorias compulsórias, da reforma universitária e do impacto desses processos na posição ocupada pela sociologia paulista no cenário nacional.

Com o golpe militar de 1964 e a seguinte repressão às lideranças acadêmicas, políticas e culturais em 1968, a situação política na Universidade de São Paulo radicalizou-se. Palco de manifestações estudantis, a FFLC na Maria Antonia enfrentou conflitos que culminaram na invasão da faculdade e no incêndio derivado da briga com os estudantes do Mackenzie, fato que acelerou a transferência de todos os cursos para a Cidade Universitária ainda nesse ano.

Meses depois da eclosão desse conflito, parte dos docentes de maior peso na Universidade de São Paulo foi aposentada compulsoriamente. Assim, lideranças como Florestan Fernandes, Fernando Henrique Cardoso e Octávio Ianni foram afastados, o que representou, não apenas a perseguição política a esses intelectuais dentro de um cenário de intensa repressão, mas, no caso da sociologia da USP, a desarticulação da “escola sociológica paulista”, capitaneada por Florestan.

A essa situação se combinaram também outros processos repressivos como a prisão de diversos alunos e professores, além do exílio de docentes como Maria do Carmo Campelo de Souza, a Carmute, e Eduardo Kuguelmas. Conforme apontou Eva Blay em entrevista à autora: "O Ruy Coelho foi preso. Eu acho interessante, porque todo mundo fala das aposentadorias, mas ninguém lembra quando ele foi preso, ficou no DOPS [Departamento de Ordem Política e Social] (...). Eu lembro que a Maria Isaura ia para a cadeia, ia ao DOPS para visitá-1o" ${ }^{61}$.

Em um cenário de grandes mudanças e radicalização política nas universidades, o curso de ciências sociais da USP teve que se reorganizar, recompondo o seu quadro docente. Nesse processo, a professora Ruth Cardoso atuou como uma das articuladoras fundamentais entre os professores afastados e os que ainda lecionavam na faculdade,

\footnotetext{
${ }^{61}$ Trecho da entrevista de Eva Blay concedida à autora em 04 de Fevereiro de 2014.
} 
visando garantir que o curso continuasse e as aulas ainda fossem ministradas (Idem). "Foi tudo muito feito "à toque de caixa", tanto a mudança do espaço físico, como a adaptação do curso, de tudo. A ideia de todos lá era que, apesar das aposentadorias, de muita gente ter sido obrigada a sair, que o curso se mantivesse em funcionamento" ${ }^{\prime \prime}$.

Desse modo, com a perda de parte expressiva do quadro docente da faculdade, diversos pós-graduandos da época foram repentinamente alçados à condição de docentes na faculdade. Nesse contexto adverso, foram contratados professores como Maria Helena O. Augusto, Maria Celia Paoli e Irene Cardoso. Apesar de tais circunstâncias, esses jovens em início de carreira tiveram, no entanto, uma oportunidade de ingressar na mais prestigiosa universidade antes de concluírem a pós-graduação ${ }^{63}$.

O período de 1964-1985 foi, portanto, um dos mais instáveis da história da sociologia uspiana e nele ocorreu uma renovação significativa do seu quadro docente com a entrada de jovens sociólogos que ainda estavam iniciando a sua carreira acadêmica. Foram esses personagens - juntamente com os docentes que permaneceram na faculdade - que se empenharam na manutenção do curso de ciências sociais nesse contexto tão hostil. Descontado o impacto negativo do afastamento de professores tão importantes, tal reordenamento implicou também certa renovação dos estudos e dos referenciais de análise da sociologia paulista. Como concluiu Irene Cardoso em entrevista: "Por que a gente foi contratada assim? Porque teve um vazio no departamento (...). A gente entrou nesse vazio, as pessoas mais jovens, eu tinha 24 anos, a Maria Helena era um ano mais, a Maria Célia um pouco mais velha, 4 ou 5 anos, foi assim que a gente entrou" (Idem).

Desse modo, "apesar das aposentadorias compulsórias de professores, das prisões, exílios forçados, do clima de ameaça permanente, [a USP] foi relativamente preservada. A comparação com a experiência na ditadura argentina é impressionante. Lá a universidade foi praticamente destruída" (CARDOSO, 2010, p. 279). Nesse sentido, é possível afirmar que, de fato, não houve "da parte do governo militar um interesse em desmantelar a universidade por completo. Houve perdas substanciais, fundamentais,

\footnotetext{
${ }^{62}$ Trecho de entrevista de Irene Cardoso concedida à autora. São Paulo, 14 de Fevereiro de 2014.

${ }^{63}$ Contudo, cabe lembrar que a maioria desses novos pesquisadores foi convidada a ingressar no quadro docente da USP como instrutores voluntários (não recebendo pagamento pelas suas atividades) ou mesmo através de contratos precários como auxiliares e assistentes de ensino, necessitando renovar o seu contrato periodicamente através da aprovação pelo conselho departamental. Conforme indica a entrevistada Maria Helena O. Augusto "essa situação foi regularizada no fïm da década de 1970 e começo de 1980 com a realização de concursos públicos para a definitiva contratação desses profissionais" (AUGUSTO, 2014).
} 
certa desorganização dos departamentos, mas os cursos foram todos mantidos" (Idem, ibidem). Enfraquecida a oposição política na USP, essa universidade manteve-se em funcionamento e buscou se adequar às diversas transformações realizadas na estrutura universitária com a reforma promovida em âmbito federal.

\section{A Reforma Universitária e sua implementação na Universidade de São Paulo}

Como visto no primeiro capítulo, a reforma universitária aprovada em 1968 inspirava-se no modelo das nas universidades norte-americanas, propondo-se a alterar diversos aspectos organizacionais, ampliar as vagas nas universidades e regulamentar a sua pesquisa e pós-graduação. Na Universidade de São Paulo, tais processos foram recebidos com fortes críticas dentro da comunidade acadêmica, que participou ativamente de todo o debate.

Em 1965, um total de 82 professores assinou um manifesto publicado na Folha de São Paulo, no qual criticavam a assistência prestada pelos técnicos da Usaid no projeto de reforma da universidade brasileira, bem como pela falta de representatividade dos professores brasileiros nas comissões responsáveis pelo estudo e elaboração de propostas:

\footnotetext{
"Jornais de São Paulo e do Rio de Janeiro, publicaram há dias atrás a notícia, não desmentida, de que o Sr. Ministro da Educação e Cultura projetava ou decidira contratar professores norte-americanos para planejarem a reestruturação das Universidades do Brasil. A ideia ministerial importa, antes de tudo, num vasto atestado de incapacidade ou incompetência passado às nossas universidades e às suas centenas de professores, no que concerne a problemas de ensino educação e cultura no país. Em todas e nenhuma delas, julgaria S. Exa. não haver, em número suficiente, professores brasileiros que recrutar para constituírem uma Comissão de Estudos e Planejamento do ensino universitário. (...) Não temos que copiar ou transplantar modelos. O que é preciso é estudá-las todas e delas extrair o que de melhor tenham e se possam enquadrá-la num sistema maleável e vivo, adaptado às condições, exigências básicas e aspirações de sociedades tão complexas como as
} 
nossas..." (Folha de São Paulo, 14 de maio de 1965, $1^{\circ}$ Caderno, p. 7$)^{64}$.

Tais resistências alinhadas com a importância intelectual e política dessa instituição no cenário nacional explicam o movimento tardio de implementação da reforma na USP, concluída apenas em 1972 a partir dos trabalhos de uma comissão de reestruturação ${ }^{65}$ organizada no âmbito do seu Conselho Universitário (Cunha, 2007, p. 125). Presidida pelo, então, reitor Gama e Silva ${ }^{66}$, a comissão foi criada em 1966 com o objetivo de estudar e propor medidas legais, estatutárias e regulamentárias necessárias à reformulação da estrutura da USP (WITTER, 2006, p. 164). Em meio a fortes resistências do movimento estudantil e por parte dos professores do chamado "baixo clero" que protestavam contra uma reforma realizada de "cima para baixo" sem o diálogo com a comunidade universitária, o decreto foi aprovado em 1969, colocando-se paulatinamente em prática nos anos seguintes (Idem, p. 180).

O primeiro aspecto que merece destaque diz respeito à organização da estrutura da universidade. Com a reforma, a USP passou a ser organizada através de institutos e faculdades que formariam as grandes unidades constitutivas de cada campus da universidade. Eles seriam formados a partir de um conjunto de departamentos em função da classificação das suas atividades (Idem, p. 184). Foi em decorrência dessa determinação que a Faculdade de Filosofia, Ciências e Letras (FFCL) passou a se denominar Faculdade de Filosofia, Letras e Ciências Humanas (FFLCH), tendo em vista a fragmentação das áreas e a criação de institutos específicos para cada disciplina como é o caso, por exemplo, da Física, Química, Biologia ou da Matemática e Estatística. Ainda que tenha apontado para autonomização dessas áreas de saber, a fragmentação da FFCL foi bastante criticada entre os docentes da faculdade que viam nesse processo o desmonte da concepção original da FFLC, que, antes de tudo, deveria ser o coração da universidade (CUNHA, 2007, p.130).

Para compor tais institutos foram criados os departamentos que seriam

\footnotetext{
${ }^{64}$ Dentre os 82 professores que assinaram o manifesto, estão: Fernando de Azevedo, João Cruz Costa, Florestan Fernandes, Ruy Coelho, Paula Beiguelman, Azis Simão, J. Artur Giannotti e Bento Prado Junior.

${ }^{65}$ A comissão era composta por além do reitor, o presidente da comissão Mário Guimarães Ferri, Tharcisio Damy de Souza Santos, Luiz de Freitas Bueno, Carlos da Silva Lacaz, Eurípedis Malavola, Erasmo Garcia Mendes, Roque Spencer Maciel de Barros, Guilherme Oswaldo Arbenz e Paulo de Carvalho Ferreira (WITTER, 2002, p. 164)

${ }^{66}$ Gama e Silva era professor catedrático da Faculdade de Direito, que assumiu o Ministério da Justiça, assinando o AI-5 em 1968 e as aposentadorias compulsórias na USP em 1969.
} 
entendidos como "a menor fração da estrutura universitária, para todos os efeitos de organização administrativa, bem como didático-científica e compreende disciplinas afins" (USP, 1969). Eliminando o regime de cátedras e a figura do "catedrático vitalício" foi possível expandir as possibilidades de acesso e progressão na carreira, que de acordo com a reforma ficaram definidas segundo a seguinte ordem:

\footnotetext{
“Artigo 85 - A carreira docente compreende os seguintes cargos e funções:

I - Professor Assistente [aqui era necessário a conclusão do mestrado]

II - Professor Assistente Doutor [aqui era necessário concluir o doutorado]

III - Professor Livre Docente [cargo aberto aos professores doutores, mediante concurso de títulos e provas];

IV - Professor Adjunto [cargo aberto aos professores livre-docentes, mediante concurso de títulos e provas]; e

V - Professor Titular [cargo aberto aos professores adjuntos, mediante concurso de títulos e provas]" (USP, 1969).
}

Antes desses níveis, ainda se previu a contratação dos auxiliares de ensino através de contratos com prazo de três anos de duração, para os quais não era obrigatória a conclusão do mestrado, apenas da graduação. Contudo, apesar da reformulação da estrutura da carreira docente, visando tornar a sua progressão mais aberta (já que dependeria dos méritos do docente e não do aval do seu catedrático), vale lembrar que a lógica das relações entre os professores continuou ainda por muitos anos a refletir o sistema de cátedras anteriormente consolidado. Conforme afirmou Cardoso em entrevista: “A cátedra foi extinta (...), mas é curioso lembrar que na verdade ela não havia acabado na prática. No departamento a hierarquia ainda permanecia, os titulares funcionavam ainda como catedráticos, embora não o fossem mais formalmente" (CARDOSO, 2010, p. 271).

Além dessas mudanças, a reforma da USP promoveu também alterações significativas no funcionamento da graduação e pós-graduação dos cursos. Se antes na graduação a maioria das disciplinas era anual, organizadas pelas cátedras que compunham o curso, depois da reforma elas passaram a ser semestrais e contabilizadas através do sistema de créditos, cujo currículo caberia a cada departamento formalizar. Essa foi uma das medidas que mais demoraram a se efetivar, sendo postas em prática somente em meados da década de 1970 (WITTER, 2006, p. 191). A pós-graduação, do 
mesmo modo, também foi reformulada, dividida em mestrado e doutorado e a criação dos programas de pós-graduação que "compreenderão cursos avançados na área de concentração escolhida pelo candidato, bem como em áreas complementares" (USP, 1969). Ainda que aprovada nesse formato em 1969, como veremos adiante, a pósgraduação sofreu uma nova reformulação com o Novo Regimento da USP aprovado em 1972, visando adequar-se ao sistema nacional de pós-graduação em voga desde 1971.

Diante dessas transformações, o curso de ciências sociais na USP foi se reorganizando de modo a se adequar a esse novo modelo de universidade. É importante lembrar o dinamismo desses processos, pois os anos de aprovação da reforma coincidem com o das aposentadorias e a contratação de novos docentes, tornando o período de 1968-1970 extremamente conturbado. Em primeiro lugar, com o novo regime, as cátedras no curso foram dissolvidas, sendo criado em seu lugar o departamento de ciências sociais, dentro do qual estavam inseridas as três áreas (sociologia, antropologia e política ${ }^{67}$ ).

Contudo, embora as três disciplinas estivessem abrigadas dentro de um mesmo departamento, a relação entre elas era profundamente assimétrica, o que se expressava no número de professores para cada uma. Em $1976^{68}$, por exemplo, havia cerca de 30 professores de sociologia, 9 de ciência política e 9 de antropologia (USP, 1976). Essa discrepância pode ser entendida se levarmos em conta a centralidade da sociologia no curso desde a sua criação. Esse quadro foi se equilibrando ao longo dos anos “... e com muita luta política dentro conselho do departamento, do departamento de ciências sociais, aí era uma luta entre as áreas (antropologia, política e sociologia), as brigas eram lá" 69 .

Outro aspecto a ser levado em conta diz respeito às trocas frequentes de áreas realizadas pelos docentes ao longo do período 1964-1985. Tendo em vista essa estrutura organizacional mais flexível, vários professores puderam trocar de área, o que é curioso, pois nem sempre as mudanças se ajustavam às suas orientações de pesquisa. Isso ocorreu com Eunice Durham e Ruth Cardoso - que saíram da antropologia e foram para a política, ainda que notadamente continuassem trabalhando dentro daquela área. $\mathrm{O}$

\footnotetext{
${ }^{67}$ A área era chamada de política, formalizando-se como ciência política apenas após a criação do departamento em 1987.

${ }^{68}$ Esse é um ano bastante significativo para tal comparação, na medida em que a partir desse período muitos dos professores que trabalhavam como instrutores voluntários já haviam sido efetivados no quadro docente da faculdade.

${ }^{69}$ Trecho da entrevista de Irene Cardoso à pesquisadora. Cf. nota 60 desse capítulo.
} 
mesmo se deu com Gabriel Cohn que foi para o departamento de ciência política assim que o mesmo foi criado em $1987^{70}$. Esse tipo de dinâmica interna é interessante, pois aponta para um contexto no qual a consolidação de cada uma dessas disciplinas ainda não estava claramente estabelecida, permitindo grande intercâmbio entre docentes.

É preciso destacar ainda a fragilidade da política nesse momento, já que essa área abrigou docentes que saíram, seja da sociologia, seja da antropologia. Como discutido em capítulo anterior, a ciência política foi, inicialmente, em São Paulo - e particularmente na USP - a disciplina com menor espaço dentro das ciências sociais. Se a sociologia uspiana se consolidou nas décadas anteriores e a antropologia constituiu uma tradição respeitável a partir dos trabalhos realizados na USP e na ELSP, a política foi se firmar como disciplina mais tarde. Tendo em vista a consolidação posterior dessa disciplina, na década de 1970 ela abrigou sociólogos e antropólogos, como afirmou Ruth Cardoso em entrevista: "Naquele momento, esse Departamento era composto também por sociólogos como Juarez Lopes, Lucio Kowarick, José Augusto Guilhon, Gabriel Cohn. Enfim, era um lugar eclético e dentro desse contexto era muito bom trabalhar lá" (CARDOSO, 1998, p.160) ${ }^{71}$.

Divididos em três áreas diferentes, esse novo quadro de docentes encontrou no sistema departamental maior espaço de atuação dentro da faculdade, sobretudo, no desenvolvimento das suas pesquisas, já que antes o pesquisador dependia fortemente do aval do seu catedrático. Essa nova configuração condicionou a ampliação do leque temático dentro da sociologia com a criação de novas de linhas de investigação dentro da disciplina. Como veremos através do recenseamento das dissertações e teses produzidas na faculdade, esse foi um dos aspectos mais inovadores do período. Não obstante, no que tange ao poder de decisão e às relações cultivadas entre os professores na faculdade, a lógica das cátedras continuou a operar na faculdade, pois "apesar de a cátedra ter sido extinta formalmente, tudo ainda funcionava de modo muito hierarquizado. A sua posição institucional, o modo como você era visto ou tratado,

\footnotetext{
${ }^{70} \mathrm{Em}$ entrevista à pesquisadora, Augusto afirmou: "Eu me lembro, por exemplo, que chorei muito, porque não queria que ele (Gabriel Cohn) fosse, mas enfim, então, do ponto de vista da criação dos departamentos, não acho que alguma vez o Gabriel tenha se tornado um cientista político, para mim ele continua sendo um sociólogo". Trecho da entrevista de Maria Helena O. Augusto concedida à autora em 24 de Janeiro de 2014.

${ }^{71}$ É interessante, nessa direção, lembrar também que os únicos titulares do departamento eram o Ruy Coelho, Azis Simão - da sociologia - e João Baptista Borges Pereira - da antropologia. Fernando Henrique Cardoso foi titular durante poucos meses até ser aposentado em 1969. O primeiro titular da área foi Leôncio Martins (vindo da sociologia) que se tornou titular em 1981, disputando esse cargo que ficou aberto desde 1969.
} 
dependia dos seus títulos. Antes do doutorado, você não era absolutamente nada!" (CARDOSO, 2010, p. 271).

A despeito da importância da titulação dentro do departamento, poucas das docentes que integraram o quadro docente da universidade daquele período lograram alcançar a posição de professora titular na sociologia ${ }^{72}$. Como relembra Eva Blay: "Antes de mim só teve uma professora titular, a professora Aparecida Joly Gouveia, depois que ela se aposentou no meu departamento, eu fui a primeira mulher, que fez concurso e entrou como professora titular" ${ }^{73}$. A dominação masculina nos cargos mais altos da docência na universidade desvela o quanto as relações de gênero continuaram a influenciar a disposição da hierarquia acadêmica na faculdade, pois mesmo com o fim das cátedras e a possibilidade do pesquisador progredir na carreira sem depender diretamente do seu catedrático, foram poucos os casos de mulheres que concorreram ao cargo de titular.

Assim sendo, apesar da abertura objetiva na progressão da carreira, é possível identificar ainda dificuldades subjetivas que levaram essas pesquisadoras a não priorizar ou mesmo considerar essa possibilidade ao longo da sua carreira acadêmica. Como apontou Augusto refletindo sobre a sua trajetória desde esse viés:

\footnotetext{
"No meu caso, eu queria estudar, quando eu vim prá cá, eu nem pensava nisso, tanto que quando eu vim para cá, eu fui convidada para ficar no departamento, eu disse que não podia, que eu já estava casada e que o meu marido trabalhava em Curitiba (...) mas aí nós viemos, mas porque ele achou que dava para vir, que valia a pena, ele mesmo queria fazer pós aqui (...) Então, não fazia parte do meu imaginário, da minha perspectiva, dos meus projetos, fazer uma carreira, isso se colocou depois" ${ }^{14}$.
}

Embora as ciências sociais tenham passado por diversas transformações na composição e organização do seu curso, muitos dos traços vivenciados no período anterior continuaram a se reproduzir na vida cotidiana do curso. Isso se expressa não apenas com posição de titular que em diversos momentos se confundia com a de

\footnotetext{
${ }^{72}$ Dentre as docentes que entraram apenas a Eva Blay se tornou professora titular em 1989. A Irene Cardoso se tornou livre docente em 1998 e Heloisa Fernandes em 1992. Já Heloísa Martins, Maria Helena O. Augusto e Maria Celia Paoli concluíram apenas o doutorado. Em contrapartida, Sedi Hirano se tornou professor titular em 1999, Brasílio Sallum Jr. em 2004 e Lísias Nogueira Negrão em 2005.

${ }^{73}$ Trecho da entrevista de Eva Blay à autora. Cf. nota. 60 desse capítulo.

${ }^{74}$ Trecho da entrevista de Maria Helena O. Augusto à autora. Cf. nota 67 desse capítulo.
} 
catedrático ou mesmo com a assimetria de mulheres docentes nessas posições, mas, inclusive, na antiga divisão entre as Cadeiras de Sociologia I e II. "A tensão não era só entre a sociologia, ciência política e antropologia, mas era entre sociologia I e II também. Isso, na verdade, acho que desapareceu agora, porque não tem mais ninguém no departamento, a maioria do pessoal já se aposentou" (Idem).

Mesmo com o afastamento das principais lideranças da Cadeira de Sociologia I, a maioria dos assistentes da Cadeira e pesquisadores vinculados ao Cesit foi incorporada pela faculdade. Nesse conjunto, destacavam-se Luiz Pereira e Marialice Foracchi (falecida em 1971) que "secundados pelo Gabriel Cohn e José de Souza Martins tiveram que sustentar a política do Florestan e segurar mais essa coisa propriamente política do departamento"75. Foram esses docentes, por um lado, e o antigo catedrático da Sociologia II, Ruy Coelho, e os assistentes dessa Cadeira, Maria Isaura P. de Queiroz e Azis Simão, por outro, que estiveram à frente da reorganização da área da sociologia na USP. Havia uma espécie de acordo tácito entre os principais grupos atuantes dentro da sociologia, esses professores buscaram dar continuidade ao curso da melhor maneira possível, tendo em vista as fortes investidas políticas contra o departamento (Idem).

A diferença entre eles ganhava forma, sobretudo, pela competição em torno da valorização de certas linhas de pesquisa e de certa imagem de competência acadêmica (Idem). A Sociologia I trabalhou mais com os grandes temas do desenvolvimento e do planejamento econômico, enquanto a Sociologia II:

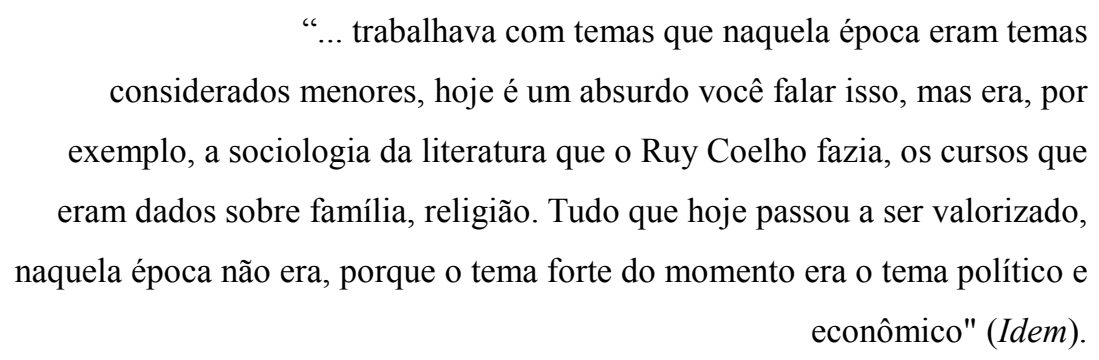

Apesar dessa clara divisão na faculdade, é possível identificar o surgimento de novos objetos de investigação, condicionados por mudanças mais amplas do curso. Desde o início da década de 1960, a questão da democratização do acesso à

\footnotetext{
${ }^{75}$ Trecho da entrevista de Irene Cardoso à autora. Cf. nota 61 desse capítulo.
} 
universidade e à ampliação das suas vagas ocupava um espaço nos debates públicos acerca da educação no país (CUNHA, 2007, p. 68). A USP não esteve isenta desse processo e as ciências sociais, por sua vez, também ampliaram o número de vagas oferecidas que passou de cerca de 35 para 200 por ano (USP, 1970, p. 13). Com um volume maior de alunos, o curso de graduação começou aos poucos a se re-organizar de modo a dar conta desse extenso volume de estudantes.

Aliado à ampliação da graduação, com a reforma universitária, as disciplinas passaram a ser semestrais e contabilizadas na forma de créditos. Para dar conta desse grande volume de alunos, as grandes disciplinas obrigatórias (na época, a Sociologia I e a Sociologia II) mesclavam aulas expositivas e seminários. Estes últimos eram dados pelos docentes que haviam acabado de entrar na universidade e estavam concluindo o mestrado/doutorado. "Então, tinha essa grande aula e a gente, digo as professoras mais novas, davam os seminários (...) o curso era dado assim. Foi um curso que, na verdade, foi bem dado assim, porque tinha esses dois suportes: A aula e mais a troca em miúdos no seminário" 76 .

A ampliação do número de optativas, assim como a diversificação das suas temáticas dentro da sociologia foi se realizando paulatinamente, na medida em que os professores foram concluindo a sua pós-graduação ${ }^{77}$. Esse foi um processo importante, na medida em que permitiu a introdução de novos autores e perspectivas de investigação na formação dos alunos no curso, como, por exemplo, através de disciplinas como "Sociologia da mulher e relações de gênero", a "Sociologia urbana" ministradas pela Eva Blay ou mesmo "Razão e Sociedade" e "Indivíduo, Razão e Liberdade", ministrados pela Irene Cardoso e Maria Helena O. Augusto. Lembrando desse processo, afirmou a Augusto: "Ninguém trabalhava com indivíduo naquele tempo, era uma coisa absolutamente fora de contexto, era uma coisa fora (porque hoje em dia todo mundo trabalha com esse tema), mas naquele tempo ninguém trabalhava"78.

Esse foi o caso não apenas dos docentes que ingressaram na universidade no fim da década de 1960, mas também daqueles que já estavam no curso desde antes e que, com o fim das cátedras, puderam explorar novos horizontes teóricos, metodológicos de

\footnotetext{
${ }^{76}$ Trecho da entrevista de Irene Cardoso à autora. Cf. nota 61 desse capítulo.

${ }^{77}$ Como aponta Irene Cardoso em entrevista à autora "a gente não dava disciplinas, a gente só foi dar disciplinas depois que fazia o doutorado, nenhum mestre podia dar disciplinas, também tinha isso. Eu fui dar disciplinas em 1980 ou 1981, aí eu dei uma disciplina minha” (Cf. nota 61 desse capítulo).

${ }^{78}$ Trecho da entrevista de Maria Helena O. Augusto à autora. Cf. nota 69 desse capítulo.
} 
investigação, trazendo esses referenciais para a graduação, como é o caso da disciplina "Sociologia da vida cotidiana" ministrada por José de Souza Martins (cujo referencial é o Henri Lefebvre) e a disciplina "Sociologia da Comunicação de Massa", ministrada por Gabriel Cohn (por sua vez, centrada no estudo dos frankfurtianos). Foi com as mudanças na estrutura de organização do curso e na própria graduação que esses docentes encontraram maior liberdade para introduzir autores até, então, eram pouco utilizados na sociologia brasileira. Como veremos a partir da análise da produção da pós-graduação do período, as pesquisas desenvolvidas na sociologia da USP passaram por diversas transformações nessa mesma direção, criando novas linhas de investigação e fazendo uso de perspectivas teóricas renovadoras.

\section{A pós-graduação da sociologia na USP}

A Universidade de São Paulo foi uma das primeiras instituições a oferecer a pósgraduação na área de sociologia no país, firmando-se como um dos centros de ensino e pesquisa de maior tradição do Brasil. Reunindo toda uma geração que marcou a história da disciplina como Florestan Fernandes, Fernando Henrique Cardoso, Octávio Ianni, Gabriel Cohn, etc; a USP se estabeleceu como um centro de referência ao longo das décadas de $1950 / 60^{79}$.

A pós-graduação na faculdade, antes da sua reformulação em 1972, no entanto, era pouco formalizada e, como não havia um sistema nacional de organização da pósgraduação, cada unidade/faculdade da USP dispunha e estabelecia as regras do seu programa. No caso das ciências sociais, havia já desde a década de 1950 o mestrado e o doutorado $^{80}$, mas existiam também as chamadas especializações. Nesse caso, o aluno tinha a obrigação de acompanhar as disciplinas oferecidas pela pós-graduação, desenvolvendo uma pesquisa, sob a orientação de um professor, mas sem a obrigatoriedade de defesa e apresentação da dissertação para uma banca. Como lembra Augusto em entrevista à autora: "Não era bem uma pós: Primeiro, porque a gente não tinha a necessidade de fazer dissertação/mestrado, tese/doutorado. O que nós fizemos

\footnotetext{
${ }^{79}$ Não à toa vários jovens recém-formados em ciências sociais vieram para São Paulo para cursar a sua pós-graduação na USP em meados da década de sessenta, como é o caso da Maria Helena e Maria Célia Paoli (de Curitiba), Sergio Miceli (Rio de Janeiro), entre outros.

${ }^{80}$ A primeira dissertação de mestrado concluída na faculdade foi em 1953 de Fernando Henrique Cardoso intitulada Evolução da Indústria em São Paulo, sob orientação de Florestan Fernandes.
} 
foi um tipo de especialização, então, a gente tinha disciplinas (que eram chamadas de pós-graduação), as disciplinas anuais e a gente conversava com os professores dessas disciplinas" ${ }^{\prime}$.

Vale ainda lembrar a centralidade do catedrático no desenvolvimento dos trabalhos, pois até então o ingresso na pós-graduação dependia quase que exclusivamente do seu aval, não havendo qualquer processo de seleção, como é realizado atualmente. $\mathrm{O}$ professor nesse caso determinava, escolhendo a dedo, não apenas quem ingressaria na pós-graduação sob a sua orientação, mas também a temática a ser pesquisada por esse estudante ${ }^{82}$. A força do catedrático na escolha dos objetos de estudo, se por um lado, consolidava perspectivas de estudo claramente delimitadas na faculdade, por outro, acabava por limitar as opções de pesquisa para os ingressantes na pós-graduação.

No entanto, com a criação do sistema nacional de pós-graduação em 1971 e a aprovação de um Novo Regimento da USP em 1972, essa situação foi complemente modificada e a pós-graduação foi reformulada em toda a universidade. Destaca-se dentre as principais mudanças nesse setor: A divisão da pós-graduação em duas etapas, mestrado e doutorado, a obrigatoriedade da indicação de um orientador, o cumprimento dos créditos em disciplinas estabelecidos para cada programa, além da defesa pública seja da dissertação (no caso do mestrado), seja da tese (no caso do doutorado) ${ }^{83}$. Abaixo seguem os artigos que explicitam tais alterações:

\footnotetext{
“Artigo 134 - Além das exigências relativas a rendimento escolar e freqüência, o candidato a grau acadêmico deverá apresentar o seguinte trabalho:

I - para Mestrado, dissertação ou trabalho equivalente, a critério da Comissão de Pós-Graduação;

II - para Doutoramento, tese, com base em investigação original.

(...)

Artigo 139 - A dissertação de Mestrado será argüida em sessão pública do Departamento, perante Comissão Julgadora, não excedendo de trinta minutos o tempo destinado tanto ao examinador quanto para o examinando.
}

\footnotetext{
${ }^{81}$ Trecho da entrevista de Maria Helena O. Augusto à autora. Cf. nota 69 desse capítulo.

${ }^{82}$ Como recontou Sergio Miceli: "Eu queria fazer uma tese sobre o tropicalismo (...), mas meu orientador, Octávio Ianni disse "Não sou eu quem define o objeto" (...) "O que você quer estudar é muito complicado, você vai ter que conversar com o Florestan", e marcamos uma hora. (...). Fui ao seu escritório, na Faculdade, e ouvi: "Olha aqui nesta lousa onde estão assinalados os objetos. Você pode escolher um deles". Eu comecei a ler. Tentei: "Professor, eu queira fazer sobre o tropicalismo, Caetano, a experiência desse grupo novo, mas o único tema cultural que estou vendo aí, e em que estou interessado é o ISEB". Ele disse: "Então é esse que você vai fazer, porque tropicalismo nem pensar, não é objeto por enquanto". (...) Ia fazer o quê? Saí com o rabo entre as pernas". (MICELI, 2006, p. 224).

${ }^{83}$ Antes do Novo Regimento, a pesquisa realizada no mestrado era também chamada de tese.
} 
Artigo 140 - A defesa de tese será realizada em sessão pública, não excedendo de trinta minutos o tempo de argüição de cada examinador". (USP, 1972).

Desse modo, com a pós-graduação re-organizada e padronizada para todos os institutos e faculdades da USP, o programa para área de sociologia foi se readequando e se re-estruturando e muitos dos alunos que já estavam desenvolvendo pesquisas (seja como especialização ou como doutorado), então, se apressaram para obter o título de mestre ou doutor ainda no modelo antigo. Como lembra Cardoso em entrevista: "Em 1972, o pessoal saiu correndo para entregar as dissertações no modelo antigo, a Maria Celia, a Heloísa Fernandes e tal, porque foi esse o período que o pessoal do departamento teve para se adaptar ao modelo federal, esse sistema integrado da pósgraduação nacional..." ${ }^{84}$. De fato, em 1972 foi possível identificar um elevado índice de defesas tanto no mestrado, quanto no doutorado (trinta e sete somente nesse ano), o que se explica se levarmos em conta que o prazo estabelecido na universidade para a conclusão das pesquisas segundo o Antigo Regimento era Dezembro de 1972.

Na tabela abaixo (Tabela 11), seguem as modalidades de trabalhos realizados tanto no mestrado quanto no doutorado - de acordo com temas de eleição. A última coluna corresponde ao percentual total de pesquisas concluídas em cada tema, somandose o que foi produzido no mestrado e no doutorado. $1985)^{85}$

Tabela 11 - Linhas de pesquisa da pós-graduação de sociologia da USP (1964-

\begin{tabular}{cccc}
\hline Áreas de investigação $^{86}$ & $\begin{array}{c}\text { Dissertações de } \\
\text { mestrado }\end{array}$ & $\begin{array}{c}\text { Teses de } \\
\text { doutorado }\end{array}$ & $\begin{array}{c}\text { Totais } \\
\text { (Dissertações+Teses) }\end{array}$ \\
\hline $\begin{array}{c}\text { Sociologia do } \\
\text { desenvolvimento }\end{array}$ & $22,43 \%$ & $21,29 \%$ & $21,89 \%$ \\
Sociologia da cultura & $20,52 \%$ & $17,60 \%$ & $19,62 \%$ \\
Sociologia rural & $12,18 \%$ & $8,33 \%$ & $10,56 \%$ \\
Sociologia da educação & $12,18 \%$ & $7,40 \%$ & $10,19 \%$ \\
\hline
\end{tabular}

\footnotetext{
${ }^{84}$ Trecho da entrevista de Irene Cardoso à autora. Cf. nota 61 desse capítulo.

${ }^{85}$ A tabela a seguir (assim como a tabela 12,) foi formulada a partir do levantamento realizado por Renato Sergio de Lima e publicado na Revista Plural em 1997. Ver LIMA, 1997.

${ }^{86}$ As áreas apresentadas nessa tabela foram se definindo tendo em vista o título, o resumo (quando houver) e a consulta à introdução dos trabalhos, visando compor um quadro o mais completo e fiel possível.
} 
Tabela 11 - Linhas de pesquisa da pós-graduação de sociologia da USP (1964-

\begin{tabular}{cccc}
\hline Áreas de investigação $^{\mathbf{8 7}}$ & $\begin{array}{c}\text { Dissertações de } \\
\text { mestrado }\end{array}$ & $\begin{array}{c}\text { Teses de } \\
\text { doutorado }\end{array}$ & $\begin{array}{c}\text { (conclusão) } \\
\text { (Dissertaçóes+Teses) }\end{array}$ \\
\hline Sociologia da religião & $4,49 \%$ & $10,18 \%$ & $6,79 \%$ \\
Mov. operário/sindicato & $3,85 \%$ & $9,25 \%$ & $6,04 \%$ \\
Sociologia da cidade & $7,05 \%$ & $3,71 \%$ & $5,67 \%$ \\
Sociologia de gênero & $3,85 \%$ & $3,71 \%$ & $3,78 \%$ \\
Teoria sociológica & $3,20 \%$ & $3,71 \%$ & $3,78 \%$ \\
Sociologia política & $2,56 \%$ & $5,55 \%$ & $3,39 \%$ \\
Identidade social & $1,28 \%$ & $3,71 \%$ & $2,26 \%$ \\
Sociologia da família & $1,28 \%$ & $0,93 \%$ & $1,13 \%$ \\
Outros & $5,13 \%$ & $4,63 \%$ & $4,90 \%$ \\
TOTAL & $\mathbf{1 0 0 \%}$ & $\mathbf{1 0 0} \%$ & $\mathbf{1 0 0 \%}$ \\
& $\mathbf{( 1 5 6 )}$ & $\mathbf{( 1 0 9 )}$ & $\mathbf{( 2 6 4 )}$ \\
\hline
\end{tabular}

Como é possível observar, existe um o padrão semelhante de linhas de pesquisa tanto no mestrado quanto no doutorado, com pequenas variações entre eles. Um primeiro aspecto que merece destaque diz respeito ao volume de trabalhos concluídos, que, em ambos os casos, cresceu significativamente nesse período. No mestrado, até 1964, haviam sido concluídas cinco dissertações (uma média de 0,45 por ano), enquanto no doutorado foram oito $(0,42)^{88}$. Já de 1964 até 1985 foram defendidas 156 dissertações $(7,42$ ao ano) e 109 teses $(5,19)$ na área de sociologia. O aumento significativo do número de vagas e de alunos dentro do curso, combinada com a crescente valorização dos títulos de mestre e doutor na carreira docente nas universidades podem ser apontados como possíveis explicações para tamanho crescimento, o que aponta para a consolidação e expansão da pós-graduação da sociologia da USP nesse período.

A eleição da sociologia do desenvolvimento foi ainda majoritária no período. Tema tradicional da sociologia uspiana desde a década de cinquenta, essa questão

\footnotetext{
${ }^{87}$ As áreas apresentadas nessa tabela foram se definindo tendo em vista o título, o resumo (quando houver) e a consulta à introdução dos trabalhos, visando compor um quadro o mais completo e fiel possível.

${ }^{88}$ Lembrando que a primeira dissertação de mestrado em Sociologia registrada na USP é de 1953, como já mencionado, e a de doutorado é anterior, de 1945. (LIMA, 2007, p. 9 e 37).
} 
continuou a movimentar parte expressiva das pesquisas na faculdade. Como recorda a entrevistada Augusto: “Olha, planejamento, desenvolvimentismo (...). Eram todos temas mais amados, eu diria. (...) Mesmo depois, se a gente pensa, por exemplo, a Maria Célia trabalhou com marginalidade no mestrado, eu com desenvolvimento, o Sedi com classes sociais, todos dialogam com essa questão, eram temas mais macro sociológicos, eu diria" 89 .

Ao lado desses trabalhos, também se fortaleceu na faculdade as pesquisas voltadas para a análise dos trabalhadores, em especial, para as mobilizações operárias, assim como a formação dos sindicatos. Tema presente na sociologia paulista desde a década de 1950, ele ganhou novo impulso dentre as pesquisas na USP, tendo em vista, sobretudo, a expansão da indústria, das organizações dos trabalhadores e das greves operárias no país no fim da década de 1970. Fortemente impactados pelo marxismo, as dissertações e teses nessa linha de investigação buscavam investigar não apenas as condições de trabalho dos operários, mas também as suas potencialidades de organização política.

Em um período de grande efervescência social, política e cultural no país e de forte oposição ao regime militar dentro das universidades, a presença do marxismo era marcante no curso. "O marxismo transformou-se em uma onda muito forte, talvez em reação ao autoritarismo reinante. Os escritos de Marx eram lidos como bíblia, como verdade indiscutível" (SALLUM Jr., 2005, p. 37). Tratava-se não apenas da influência da obra de Marx, mas, também, de vários dos seus intérpretes que ganhavam destaque no cenário internacional como Althusser, Gramsci, Lukács, etc. Revisitando a sua formação, Sergio Miceli afirma na mesma direção em entrevista à autora: "Para a minha geração era uma coisa importante [o marxismo], porque são obras que tiveram muito impactos quando eu era jovem... Althusser. Era lido como se fosse uma bíblia, eu sabia praticamente de cor (...) o marxismo era uma presença" ${ }^{\text {9 }}$.

A segunda área de pesquisa mais explorada foi a sociologia da cultura com $19,62 \%$ das dissertações e teses defendidas. Assim sendo, embora tenham se estabelecido na universidade cerca de 10 áreas de pesquisa diferentes, a antiga polarização entre as Cadeiras de Sociologia I e II continuou a marcar as divisões de trabalho e de pesquisa na faculdade mesmo depois da efetivação da reforma na USP.

\footnotetext{
${ }^{89}$ Trecho da entrevista de Maria Helena O. Augusto à autora. Cf. nota 69 desse capítulo.

${ }^{90}$ Trecho da entrevista de Sergio Miceli à autora realizado em 05 de Novembro de 2013.
} 
Dentre todas as dissertações produzidas quase metade delas $(41,51 \%)$ eram dentro da temática do desenvolvimento ou da cultura com uma pequena diferença entre elas (2,27\%). Como vermos adiante, apesar do elevado índice, esses trabalhos passaram por importantes transformações, incorporando novas referências e perspectivas de análise.

Outra área de investigação bastante explorada foi a sociologia rural. Orientados, sobretudo, por Maria Isaura Pereira de Queiroz, que via nas camadas pobres e desprovidas de recursos materiais uma dimensão fundamental para o entendimento da sociedade brasileira e das mudanças sociais no país (BÔAS, 2009, p. 286), as teses e dissertações nessa abordagem se voltaram, por sua vez, para as condições de trabalho, as relações sociais cultivadas, assim como as relações de poder ali estabelecidas.

Nesse ponto, é possível identificar outra dimensão fundamental na distinção dos trabalhos das Cadeiras de Sociologia I e II. Eva Blay sintetizou essas diferenças com bastante propriedade ao afirmar que:

"Tinham dois temas de pesquisa. Tinha a Sociologia I (...) eles eram mais quantitativos, mais quantitativistas, mais voltado para uma sociologia quantitativa. E tinha o outro lado, o pessoal do professor Ruy, Maria Isaura, Azis, que era mais qualitativo (...) havia uma tensão muito grande entre essas duas linhas. Um grupo era mais voltado para a industrialização, esse lado econômico, e o outro lado era muito mais voltado para as relações sociais, para as comunidades, para a vida em comunidade, seja em sindicato, seja no campo, seja nas relações de poder" ${ }^{\prime 91}$.

Trata-se, portanto, de entender que a relação entre as antigas cátedras continuaram de certo modo a operar na faculdade, delimitando não somente universos temáticos de investigação, mas principalmente modos de apreensão e interpretação dessas realidades. Enquanto os docentes remanescentes da Sociologia I continuaram a valorizar o processo mais amplo de desenvolvimento brasileiro, buscando apreender as suas possibilidades e também os grandes impasses para a sua realização, àqueles anteriormente vinculados à Sociologia II - e especialmente à Queiroz - estavam atentos às "diferenças" e contradições presentes na sociedade brasileira não apenas como obstáculos a superar, mas como parte constitutiva da vida social no país.

\footnotetext{
${ }^{91}$ Trecho da entrevista de Eva Blay. Cf. nota 60 desse capítulo.
} 
Uma das iniciativas mais importantes na proliferação desses estudos foi a criação do Centro de Estudos Rurais e Urbanos (CERU). Fundado em 1964, como “Centro de Estudos Rurais", ele passou a se chamar CERU em 1968, tendo em vista a grande atenção despertada para os problemas urbanos na sociologia (QUEIROZ, 1995, p. 19). Organizado como uma sociedade civil sem fins lucrativos, objetivos econômicos políticos e religiosos, essa entidade era destinada a fornecer aos alunos do curso de ciências sociais a possibilidade de realizar pesquisas e experiências de campos, contribuindo para a formação mais sólida desses sociólogos na USP (Idem, p. 16). Firmando alguns convênios importantes como com o Serviço do Vale do Ribeira ${ }^{92}$, a Comissão executiva do Plano de Recuperação Econômico-Rural da lavoura Cacaueira (CEPLAC) e a FAPESP, o centro permitiu o desenvolvimento de uma série de pesquisas, que originaram parte expressiva das dissertações e teses defendidas dentro da sociologia rural e orientadas por Queiroz.

Em 1968 foi criado os Cadernos CERU, publicação anual que se mantém até hoje e que se destina à divulgação das pesquisas promovidas no centro, assim como foi promovido também o Encontro Nacional de Estudos Rurais e Urbanos em 1973, realizando-se anualmente e reunindo pesquisadores de todo o país. Assim como argumentado no caso do IUPERJ, do Museu Nacional e do CEBRAP, a criação de um centro de pesquisas independente demonstra ter sido uma estratégia extremamente perspicaz e oportuna naquele momento, pois escapando do "peso da estrutura universitária" (Idem, ibidem), esses pesquisadores puderam angariar recursos para manter viva essa tradição de estudos e expandir a sua atividade dentro da faculdade ${ }^{93}$.

Os estudos em torno da sociologia da educação também cresceram dentro da faculdade com a entrada de Aparecida Joly Gouveia no quadro de docentes em 1966. Ela foi formada em ciências sociais pela ELSP, concluindo o seu doutorado em Chicago em 1962. Durante a década de cinquenta, trabalhou no Centro Brasileiro de Pesquisas Educacionais (CBPE) organizado por Anísio Teixeira como parte integrante do Inep (Instituto Nacional de Pesquisas Educacionais), que reuniu importantes sociólogos como Costa Pinto e o próprio Luiz Pereira. Ali Gouveia desenvolveu uma série de

\footnotetext{
${ }^{92}$ Esse serviço era pertencente à Secretaria de Serviços e Obras Públicas do Estado de São Paulo.

${ }^{93}$ Como relata Eva Blay em entrevista à pesquisadora: "A Maria Isaura teve a inteligência de criar esse espaço para facilitar a pesquisa, porque não tinha no departamento um lugar com tanta autonomia de fazer convênios, de reunir os alunos, fazer seminários, pois a situação na faculdade não era que nem hoje, que todo mundo consegue a sua bolsa para fazer pesquisa e tal. Eram ainda muito precários esses recursos”. Cf. nota 60 desse capítulo.
} 
trabalhos centrados na análise do ensino médio no país, focalizando processos como o acesso, a evasão escolar, a repetência, as aspirações profissionais dos estudantes formados, etc (LUDKE, 2010, p. 25).

Em 1966, Gouveia foi convidada por Azis Simão para integrar o quadro de docentes da USP, lecionando nessa instituição até se aposentar em 1989. A docente já era reconhecida pela sua experiência como pesquisadora no CBPE e logo se tornou uma referência dentro dessa linha de investigação, orientando parte expressiva dos trabalhos realizados nessa temática $(40,74 \%)$. Em geral, as pesquisas tiveram duas tônicas principais: A primeira, voltada para o estudo do ambiente escolar em clara consonância com as pesquisas realizadas pela socióloga anteriormente ${ }^{94}$. Já a segunda leva de estudos estava focada na análise das políticas educacionais, voltando a sua atenção para as legislações e programas governamentais empreendidos, sobretudo, pelo governo militar $^{95}$. A implementação de uma série de reformas e novos programas pelo governo, com destaque para a reforma universitária de 1968, acabou se tornando material para muitos dos estudos nessa direção, uma tendência vivida nacionalmente dentro dessa especialidade (NEVES, 2002, p. 360).

Por fim, com um índice menor de trabalhos concluídos, vale à pena sinalizar também o surgimento de novas linhas temáticas como a sociologia de gênero, da família, da cidade ou mesmo a sociologia política. Essa última adquire espaço na faculdade em disputa direta com a ciência política em destaque no cenário nacional, fortemente marcada pelo enfoque nos aparatos institucionais que davam corpo ao Estado brasileiro. Como explorado no capítulo anterior, as instituições políticas tornaram-se um objeto de predileção e de debate entre os cientistas políticos que buscavam entender - atribuindo maior ou menor destaque aos aspectos institucionais - a conjuntura política inaugurada com o golpe militar de 1964.

Na Universidade de São Paulo, no entanto, tendo em vista a frágil constituição da ciência política dentro do curso de ciências sociais (SILVA, 2008, p. 31), os estudos nessa direção foram absorvidos também pela própria sociologia que se voltou para objetos como o Estado e a democracia. Buscando se colocar como uma alternativa a

\footnotetext{
${ }^{94}$ A dissertação de Mauro Wilton de Souza sobre os alunos de madureza (1972), a da Alice Beatriz S.G. Lang (1980) e Maria Aparecida dos Santos (1980) sobre as aspirações dos estudantes constituem bons exemplos nessa direção.

95 Já aqui cabe apontar a dissertação de Silvia Maria Manfredi sobre o Programa Nacional de

Alfabetização (1976) e o trabalho de Lia Zanotto Machado (1979) sobre política educacional e ideologia.
} 
esse tipo de estudo, os pesquisadores uspianos argumentaram a seu favor, atribuindo ao sociólogo:

“a missão intelectual de desenvolver uma Sociologia Política que (...) possa renovar aquele tipo de trabalho [o da ciência política], introduzindo sistematicamente as dimensões institucionais e simbólicas na reconstrução das relações de dominação e da luta política" (SALLUM, 2002, p. 86).

A partir de declarações como essa, é possível apreender duas dimensões fundamentais nesse processo. A primeira diz respeito à importância da temática do Estado e do regime político brasileiro dentro das ciências sociais de modo mais amplo, o que aponta para uma tendência de investigação do período. Em segundo lugar, esse debate permite destacar a força institucional da sociologia diante da antropologia e da ciência política em São Paulo, mesmo depois de 1964. Essa é uma característica presente na USP, mas que ressoou em outras instituições paulistas como o CEBRAP, na medida em que ambos valorizaram a dimensão das relações sociais para o entendimento do funcionamento da vida política. A importância da tradição sociológica em estudos de viés claramente político em São Paulo pode ser compreendida se levarmos em conta a hegemonia anterior dessa disciplina na capital paulista, o que acabou influenciando toda uma geração de pesquisadores em seus trabalhos sobre a esfera política no Brasil.

Outro aspecto interessante de destacar (e que se expressou tanto no mestrado, como no doutorado) foi a pouca expressão dos estudos sobre a assimilação cultural. Não apenas foram encontrados poucos trabalhos nessa direção, como eles foram desaparecendo ao longo dos anos dentro da sociologia. Centradas, por sua vez, principalmente nos estudos sobre os processos migratórios ou sobre as sociedades rurais, a sociologia não deixou de sublinhar o seu compromisso com essa questão (PEIXOTO; SIMÕES, 2003, p. 351), mesmo fazendo sempre questão de demarcar uma distância com relação aos estudos de comunidade ${ }^{96}$. Isso reverberou nas dissertações e teses produzidas na faculdade que trataram dessa questão, mesmo contando com um número reduzido de trabalhos.

\footnotetext{
${ }^{96}$ Um exemplo disso foi o prefácio escrito da tese de Antonio Candido Os parceiros do Rio Bonito, no qual o autor destaca que "Abordam-se aqui os problemas que vêm sendo, em nosso país, estudados através da estatística e monografias de comunidades. Essa tese não é uma coisa nem outra (...) não é um "estudo de comunidade", no sentido hoje corrente, sobretudo entre americanos e ingleses. (...) Depois de bastante hesitar, rejeitei esse ponto de vista" (CANDIDO, Antonio, 2010, p. 24).
} 
Contudo, tais estudos foram perdendo espaço na faculdade ${ }^{97}$. Parte disso se explica pelo destaque de outras questões na agenda política do país como a situação dos trabalhadores, a política econômica brasileira e as instituições políticas, mas também pode ser entendida se for levado em consideração que o destaque desse tipo de abordagem foi se configurando em um momento marcado pelo forte diálogo entre a sociologia e a antropologia. Tratava-se, até então, de uma antropologia em estreita colaboração com a sociologia, na qual os pesquisadores não só compartilhavam temas e orientações teóricas, mas também se deslocavam freqüentemente de uma disciplina para a outra (DURHAM, 1982, p. 161). Todavia, com o processo de especialização crescente entre as disciplinas nos anos seguintes, esse diálogo foi se tornando cada vez mais estreito, levando à produção de poucas teses e dissertações dentro dessa problemática na sociologia, restringindo esses trabalhos, sobretudo, para a área da antropologia.

Segue agora a relação completa de professores que orientaram tanto no mestrado quanto no doutorado:

Tabela 12 - Relação de orientadores no mestrado e doutorado da USP (1964-1985)

(continua)

\begin{tabular}{cccc}
\hline Professor & $\begin{array}{c}\text { Porcentagem } \\
\text { (no mestrado) }\end{array}$ & $\begin{array}{c}\text { Porcentagem } \\
\text { (no doutorado) }\end{array}$ & $\begin{array}{c}\text { Porcentagem total } \\
\text { (mestrado+doutorado) }\end{array}$ \\
\hline Ruy Coelho & $10,90 \%$ & $14,67 \%$ & 12,45 \\
Luiz Pereira & $8,97 \%$ & $13,76 \%$ & 10,94 \\
\hline Aparecida Joly & $10,90 \%$ & $5,50 \%$ & 8,68 \\
Maria Isaura P. de Queiroz & $7,70 \%$ & $10,09 \%$ & 8,68 \\
\hline Leôncio Martins & $7,06 \%$ & $6,42 \%$ & 6,79 \\
Gabriel Cohn & $6,41 \%$ & $7,34 \%$ & 6,79 \\
\hline Fernando Mourão & $7,06 \%$ & $4,59 \%$ & 6,03 \\
Florestan Fernandes & $5,13 \%$ & $7,34 \%$ & 6,03 \\
\hline Henrich Rattner & $2,57 \%$ & $7,34 \%$ & 4,53 \\
\hline José de Souza Martins & $3,85 \%$ & $3,67 \%$ & 3,77 \\
Diva Benevides Pinho & $5,13 \%$ & $0 \%$ & 3,40 \\
\hline Francisco Weffort & $3,21 \%$ & $3,67 \%$ & 3,02 \\
\hline José Pastore & $3,85 \%$ & $0,92 \%$ & 2,64 \\
\hline Juarez Brandão & $3,21 \%$ & $1,83 \%$ & 2,64 \\
\hline
\end{tabular}

${ }^{97}$ A última tese identificada nessa pesquisa com essa temática foi defendida em 1972, por exemplo. 
Tabela 12 - Relação de orientadores no mestrado e doutorado da USP (1964-1985)

(conclusão)

\begin{tabular}{cccc}
\hline Professor & $\begin{array}{r}\text { Porcentagem } \\
\text { (no mestrado) }\end{array}$ & $\begin{array}{c}\text { Porcentagem } \\
\text { (no doutorado) }\end{array}$ & $\begin{array}{c}\text { Porcentagem total } \\
\text { (mestrado+doutorado) }\end{array}$ \\
\hline Azis Simão & $1,93 \%$ & $2,75 \%$ & 2,26 \\
Lísia Nogueira Mourão & $1,93 \%$ & $0,92 \%$ & 1,51 \\
Teófilo Filho & $1,93 \%$ & $0,92 \%$ & 1,51 \\
Carlos Marques Pinho & $1,26 \%$ & $0,92 \%$ & 1,13 \\
Eva Blay & $1,26 \%$ & $0,92 \%$ & 1,13 \\
Lia Fukui & $1,26 \%$ & $0,92 \%$ & 1,13 \\
José Carlos Pereira & $0,64 \%$ & $1,83 \%$ & 1,13 \\
Octávio Ianni & $0,64 \%$ & 0,38 & 0,38 \\
Oliveiro Ferreira & $0,64 \%$ & $0 \%$ & 0,38 \\
Lúcio Kowarick & $0,64 \%$ & $0 \%$ & 0,38 \\
Liana M. Silva Trindade & $0,64 \%$ & $0 \%$ & 0,38 \\
Candido Procópio & $0,64 \%$ & $0 \%$ & 0,38 \\
Ruth Cardoso & $0 \%$ & $0,92 \%$ & 0,38 \\
\hline Jose Carlos Prandi & $0 \%$ & $0,92 \%$ & 0,38 \\
Paul Hugon & $0 \%$ & $0,92 \%$ & 0,77 \\
Desconhecido & $0,64 \%$ & $0,92 \%$ & $\mathbf{1 0 0 \% - 2 6 5}$ \\
Total & $\mathbf{1 0 0 \%}-\mathbf{1 5 6}$ & $\mathbf{1 0 0 \%}-\mathbf{1 0 9}$ & \\
\hline
\end{tabular}

Os docentes que mais orientaram no período foram Ruy Coelho, Luiz Pereira, Maria Isaura P. de Queiroz e Aparecida Joly Gouveia que juntos somam cerca de $40 \%$ das orientações realizadas. Em sua maioria, cada um desses professores concentrou orientações em suas respectivas linhas de pesquisa, a saber: sociologia da cultura no caso do primeiro $(66,66 \%)$, a sociologia do trabalho/desenvolvimento no caso do segundo $(62,06 \%)$, a sociologia rural no caso da terceira $(47,82 \%)$ e a sociologia da educação no caso da última $(47,82 \%)$, não à toa as temáticas com maior volume na faculdade.

É interessante notar também que mesmo atuando em outras áreas, professores como Ruth Cardoso (antropóloga nucleada na ciência política) ou Francisco Weffort (cientista político) orientaram alunos na sociologia. Isso se explica pela situação institucional da faculdade, na qual as três áreas estavam agregadas dentro de um mesmo 
departamento (o das ciências sociais), o que permitiu alguma flexibilidade e possibilidade de trânsito entre as áreas pelos docentes. Como afirmou Maria Helena O. Augusto: "Na verdade, você tinha uma tendência de localização, mas você tinha também uma transição bem razoável"98. Assim docentes como "Eunice e a Ruth Cardoso, que eram antropólogas desde o nascimento, foram primeiro para área e depois para o departamento da ciência política, mas continuaram a orientar na antropologia e às vezes até na sociologia" (Idem). Conforme visto anteriormente, essas trocas de áreas se relacionaram muito mais a controvérsias e diferenças pessoais do que escolhas disciplinares, o que é um indício do quanto o processo de consolidação das três disciplinas na USP foi se realizando gradativamente e com certa dose de tensão na Universidade de São Paulo ao longo desses anos.

Não obstante, foi expressivo o crescimento de docentes no quadro da sociologia uspiana (no total 29, 26 se considerarmos aqueles que se afastaram da universidade no fim dos anos sessenta) $)^{99}$, o que nos ajuda a ter uma dimensão da expansão da pósgraduação no curso. É interessante notar, no entanto, que mais da metade desses professores orientou menos de $3,00 \%$ das pesquisas, somando-se o mestrado e doutorado ao longo de vinte anos. O pouco volume de orientações desse conjunto de docentes se explica pela entrada de toda uma nova de geração de cientistas sociais depois das aposentadorias compulsórias, docentes que, inclusive, ainda não haviam concluído o mestrado ou o doutorado. Esses intelectuais puderam orientar trabalhos somente anos depois, o que explica a grande quantidade de professores com poucas orientações concluídas no período.

Assim sendo, se Ruy Coelho, Aparecida Joly Gouveia, Luiz Pereira e Maria Isaura P. de Queiroz eram responsáveis por parte significativa das orientações, aos poucos esse cenário foi sendo alterado. Em termos de linhas de pesquisa, esse crescimento de orientadores representou não apenas a multiplicação de novas temáticas e especialidades dentro da sociologia, mas também a consolidação de novos personagens e perspectivas dentro de uma mesma área. As orientações de trabalhos dentro da sociologia da cultura, por exemplo, são bastante significativas nessa direção. Ruy Coelho e Gabriel Cohn foram os docentes que mais orientaram trabalhos nessa

\footnotetext{
${ }^{98}$ Trecho da entrevista de Maria Helena O. Augusto à pesquisadora. Cf. nota 69 desse capítulo.

${ }^{99}$ Cabe lembrar que o número de docentes expressos nessa tabela não compreende ao número total de professores da área de sociologia, pois muitos deles ainda não haviam concluído o mestrado/doutorado, orientando alunos apenas depois de 1985.
} 
área ${ }^{100}$, contudo, cada qual foi se consolidando como uma referência na área com objetos de análise de sua predileção e inspirações teóricas e metodologias bastante diversificadas.

Os trabalhos orientados por Ruy Coelho, por exemplo, tem como ênfase central a valorização dos objetos considerados "nobres" da nossa cultura. Considerando todos os trabalhos orientados na área da sociologia da cultura (tanto no mestrado, quanto no doutorado), mais da metade deles tinha como objeto a literatura $(57,9 \%), 15,8 \%$ o teatro, seguidos por $10,5 \%$ voltados para a música, cujo mesmo percentual também teve os estudos sobre a pintura. A predileção dessas atividades culturais como objeto de investigação sociológica certamente se relaciona com a trajetória intelectual de Ruy Coelho e sua passagem pela Revista Clima.

Isso, porque, formado em filosofia (1941) e em ciências sociais no ano seguinte, Ruy Coelho foi membro do grupo fundador da revista Clima junto com Antonio Candido, Décio de Almeida Prado e Lourival Gomes Machado. Ambicionando renovar a crítica cultural da época, o grupo alçou grande destaque no cenário paulista pela nova abordagem - mais universitária e acadêmica - introduzida para avaliar a produção cultural (PONTES, 1998, p.109). Dentro do grupo, o jovem intelectual se destacava, em primeiro lugar, pela sua versatilidade. Enquanto os outros colaboradores centraram as suas publicações em um ramo específico da vida artística, tendendo a ser mais cautelosos no tratamento dos temas que fugiam às áreas de competência para as quais se autodesignaram, Ruy Coelho não hesitava, publicando artigos sobre diferentes assuntos como a literatura, teatro, cinema, etc. (Idem, ibidem).

Do mesmo modo, o autor reivindicava a supremacia da filosofia para a análise dos fenômenos culturais, na medida em que "o filósofo seria aquele que, vivendo o drama humano em sua plenitude, se alça acima dele, tentando formular suas experiências em ideias abstratas. O artista as cristaliza em sentimentos, em emoções, em vibrações" (COELHO, apud, PONTES, 1998, p.109).

Essas duas dimensões (a versatilidade e a perspectiva filosófica) marcaram a atividade desse intelectual como professor de sociologia na USP. Realizando o seu doutorado nos Estados Unidos na década de cinquenta, Ruy Coelho voltou ao Brasil,

\footnotetext{
${ }^{100}$ Juntos os dois somam 59,61\% das dissertações e teses orientadas dentro da sociologia da cultura. Ruy Coelho orientou 42,30\% delas e Gabriel Cohn 17,31\%, lembrando que o segundo concluiu o seu doutorado somente em 1971, concluindo a sua primeira orientação somente em 1974.
} 
disputou com Octávio Ianni e ganhou a posição de catedrático da Cadeira de Sociologia II ainda em 1964. Com as aposentadorias compulsórias e a reforma universitária, Ruy Coelho passou a ser professor titular e foi chefe do, então, departamento de ciências sociais em 1979. Consolidando-se como uma das figuras remanescentes da Cadeira de Sociologia II, Ruy Coelho orientou uma parcela significativa dos trabalhos realizados na área da sociologia da cultura nas décadas de sessenta e setenta.

Tais trabalhos acabaram sendo marcados por essa perspectiva menos rígida acerca das fronteiras disciplinares entre a sociologia e a filosofia no estudo das manifestações culturais. Isso, porque nessas obras, o que se identifica é a forte tendência a uma leitura que privilegie os aspectos internos dessas obras, valorizando o exame do próprio corpus literário, a sua articulação e problematização próprios, voltando a sua atenção para as qualidades intrínsecas ao texto.

Teófilo de Queiroz Júnior, por exemplo, em sua dissertação de mestrado acerca do preconceito de cor e da figura da mulata na literatura brasileira, introduz o seu estudo afirmando ter como preocupação central "procurar averiguar, não mais os condicionamentos sociológicos atuantes na literatura, mas a sua recíproca. E recorremos a tal procedimento com o intuito de pelo menos indicar o quadro dentro do qual se estabelecem certas relações entre as características formais da narrativa e seu conteúdo ideológico" (QUEIROZ, 1975, p.15). Desse modo, o sociólogo perpassa importantes autores da literatura brasileira (como Gregório Matos, Jorge Amado e Aluísio Azevedo) buscando rastrear, no interior do próprio texto, a maneira através da qual o estereótipo da mulata foi sendo construída por esses escritores.

Ao lado desse tipo de produção foram surgindo também um conjunto de novos estudos na área da sociologia cultura que buscaram, por sua vez, refletir sobre o desenvolvimento da indústria cultural no país. A tese de doutoramento de Gabriel Cohn constituiu a primeira iniciativa nessa direção. Nesse texto capital, o autor propõe fundamentar a análise sociológica da comunicação (e a sua cristalização no plano cultural), explorando a relação entre sistemas simbólicos e sistemas sociais no quadro do capitalismo monopolista e a sua manifestação no âmbito da cultura, da indústria cultural, que passa a caracterizar a vertente mais caudalosa da produção de bens simbólicos e redefinir o estatuto das demais (COHN, 1973, p. 13). A partir desse trabalho inicial e da disciplina elaborada pelo sociólogo para a graduação chamada Sociologia da Comunicação de Massa no início da década de setenta, seguiu-se uma 
safra de trabalhos dentro dessa mesma linha de investigação, tomando a Escola de Frankfurt, e especialmente o Theodor Adorno, como referenciais centrais de análise sociológica.

Articulando a questão do Estado autoritário e modernizador com as manifestações da cultura de massa, que adquiriram força com a emergência e a expansão do sistema da indústria cultural no país, a teoria adorniana permitia refletir sobre a cultura em relação direta com o regime político vivido no país. Como lembra Gabriel Cohn: "Fazia sentido discutir a indústria cultural, ideologia, personalidade autoritária. (...) Eram tempos complicados.” (COHN, 2007, p. 118). Na mesma direção, afirmou Maria Arminda N. Arruda: “Analisar a cultura e tratar dela, tornou-se lugar privilegiado para se refletir sobre a sociedade (...). Isto é, com a modernização instaurada com o regime militar, a indústria cultural era um componente fundamental (...) para legitimar o processo de modernização e de dominação" (ARRUDA, 2007, p. 358-359).

Fortemente impactados pela introdução dessa nova perspectiva de estudos foram sendo produzidas as primeiras dissertações/teses, em sua grande maioria, orientadas por Gabriel Cohn como as dissertações de Maria Arminda do Nascimento Arruda, Gisela Taschner, Waldenyr Caldas, e Orlando Pinto Miranda. Além de tomarem a perspectiva adorniana como inspiração para as suas pesquisas ${ }^{101}$, os estudos desenvolvidos inovaram nesse cenário por elegerem objetos de investigação ainda pouco consagrados na área. Arruda voltou-se para o estudo do campo publicitário, Taschner para o jornalismo, Caldas a música sertaneja e a indústria cultural e Miranda sobre o personagem de quadrinhos Tio Patinhas ${ }^{102}$.

Identifica-se, portanto, uma renovação dos objetos de investigação nessa especialidade, com destaque à grande imprensa, os meios de comunicação e propaganda e a cultura popular. Ainda que inevitavelmente temas como o desenvolvimento econômico, planejamento nacional, industrialização e urbanização fossem tomados como carros-chefes da sociologia uspiana, cabendo às investigações no campo da cultura uma posição secundária, é de extrema importância apontar que, mesmo dentro dessa área, é possível identificar transformações importantes tanto em nível de objeto de

\footnotetext{
${ }^{101}$ Todos esses trabalhos citam Theodor Adorno em sua bibliografia ao menos uma vez, apresentando-o como referência teórica das presentes pesquisas. Ver: ARRUDA, 1979; TASCHNER, 1978; CALDAS, 1976 e MIRANDA, 1975.

102 Para uma análise mais detida desses trabalhos, ver ROCHA, 2011.
} 
pesquisa quanto de referência teórica, dialogando diretamente com a emergência de um regime político autoritário no país.

De modo mais amplo, é possível identificar esta como uma das características mais marcantes dos trabalhos realizados na Universidade de São Paulo, isto é, o impulso de analisar, em maior ou menor medida e desde ângulos distintos, à situação política vivida no país. Nessa direção, apesar da organização da pós-graduação e a multiplicação de linhas de investigação na sociologia, a conjuntura social e política brasileira continuou a moldar o olhar do sociólogo e a sua produção, tornando ainda mais complexo o processo de autonomização dessa disciplina no Brasil. Esse foi um aspecto recorrente tanto na ciência política como na antropologia, o que sugere a interferência ainda marcante da vida política brasileira nas pautas de investigação realizadas dentro das ciências sociais no país.

\section{A sociologia uspiana no quadro de expansão nacional das ciências sociais}

Quando se trata de refletir sobre o curso de ciências sociais da Universidade de São Paulo durante a ditadura militar, não se pode negligenciar as aposentadorias compulsórias, os exílios e as constantes investidas políticas realizadas dentro do curso (MARTINS, 1981, p. 27). Entretanto, a despeito da importância desses processos, cabe destacar também que a entrada de toda uma nova geração de pesquisadores possibilitou a introdução de variadas perspectivas de estudo e especialidades que foram fundamentais para a consolidação de linhas de investigação diversificas dentro da USP. Dispondo de uma margem maior de atuação na faculdade, depois do fim do regime de cátedras, esses professores encontraram espaço para empreender diversos projetos de estudo e introduzir novas referências teóricas de análise, dinamizando a pesquisa na universidade.

No entanto, apesar da especialização em curso, é possível notar certa unidade na produção do período, orientada para a questão mais abrangente do Estado autoritário e da democratização. Seja através da sociologia do desenvolvimento ou do trabalho, seja dentro da sociologia rural, seja no campo da cultura, todos os trabalhos buscaram em certa medida entender e problematizar o regime político brasileiro. A força da conjuntura política nas pesquisas sociológicas revela o quanto o desenvolvimento e 
consolidação das ciências sociais constituíram um processo tortuoso e prolongado, inclusive, dentro da própria sociologia, disciplina que já desde a década de cinquenta, dispunha de maior dianteira com relação à antropologia e ciência política no cenário institucional.

Outro aspecto que merece destaque diz respeito à posição de liderança dos sociólogos da Universidade de São Paulo dentro do quadro mais amplo das ciências sociais brasileiras. Isso porque, se até 1964 existiam poucas instituições de ensino e pesquisa, depois disso, não apenas a antropologia e a ciência política se firmaram como disciplinas de destaque dentro das ciências sociais, como também foram sendo criados novos lugares de debate e pesquisa na área, com destaque especial aos centros de pesquisa e programas de pós-graduação independentes das universidades.

Como visto no capítulo anterior, esses institutos estiveram na dianteira de importantes transformações na agenda de pesquisas e debates travados no interior das ciências sociais. Reunindo figuras de renome das ciências sociais, esses espaços tiveram o seu financiamento garantido através da Fundação Ford, o que permitiu a multiplicação de pesquisas nas áreas por esses intelectuais que, liberados dos encargos que envolviam a graduação nas universidades, puderam centrar os seus esforços na concretização desses projetos de investigação. Todas esses condicionantes favoreceram a expansão e o destaque de iniciativas desse tipo, enquanto na universidade (sobretudo na USP), os professores ainda procuravam reorganizar o seu quadro docente depois das aposentadorias, buscando dar conta dos cursos de graduação e pós-graduação, tendo em vista o crescimento do número de alunos na universidade. É nesse cenário que o papel inovador da sociologia da USP foi posto em dúvida:

"Isso começou a causar uma sensação de desconforto. Primeiro, porque a USP estava fragilizada e segundo também, porque começou uma discussão que levou bastante tempo, um pouco no sentido das falas do Giannotti de que "a USP havia acabado como lugar de pesquisa, que agora era o Cebrap" (...). Foi um período muito difícil, como se a USP não fizesse mais nada, como se a sociologia da USP não produzisse nada e não era bem $\operatorname{assim}^{103}$.

\footnotetext{
${ }^{103}$ Trecho da entrevista de Irene Cardoso à autora. Cf. nota 61 desse capítulo.
} 
Uma expressão dessa dificuldade tenha sido o fato de a sociologia uspiana não ter organizado uma revista própria de sua área ${ }^{104}$, na qual divulgasse os trabalhos realizados, promovendo debates com pesquisadores e intelectuais do país inteiro, tal como visto no caso da ciência política ou mesmo dentro da antropologia. Ao contrário do período anterior, no qual a falta de uma revista era compensada com a intervenção sistemática em todas as publicações existentes, o que garantiu forte projeção e destaque de Florestan Fernandes e seus assistentes no cenário intelectual (JACKSON, 2004, p. 276); os sociólogos que permaneceram na faculdade participaram esporadicamente e de modo muito disperso nas revistas, o que reforça essa perda de visibilidade da sociologia da $\mathrm{USP}^{105}$.

Todos esses condicionantes acabaram limitando as possibilidades de pesquisa sociológica na USP que acabou centrada nos trabalhos realizados pela pós-graduação. Apesar do volume de dissertações e teses produzidas, institutos como o CEBRAP, o IUPERJ ou o PPGAS do Museu Nacional rivalizaram com a USP, pois além do elevado número de pesquisas organizadas - e alinhadas com grandes debates nacionais do período -, os seus idealizadores participaram sistematicamente ou mesmo fundaram revistas especializadas na área, do mesmo modo em que se envolveram em associações como a ABA, a ANPOCS, etc; o que trouxe maior visibilidade e autoridade para esses grupos no cenário acadêmico.

Se levarmos em consideração a publicação de livros, esse mesmo desenho se reproduz. Ainda que entre os docentes da USP a maioria dos professores na sociologia tenha conseguido publicar no mínimo o seu mestrado e doutorado, é importante lembrar que essa situação foi decorrente de conjuntura favorável de aquecimento do mercado editorial, que beneficiou não apenas os pesquisadores uspianos, mas todos os cientistas sociais brasileiros, tal como visto no capítulo anterior no caso da antropologia. Desse modo, longe de se apresentar como uma prerrogativa vivenciada na Universidade de São Paulo, a publicação de livros acabou se constituindo como um recurso acessível a muitos dos pesquisadores da área. Maria Isaura Pereira de Queiroz foi a docente que mais publicou livros na FFLCH até 1985 (no total foram dez em português, além de seis traduções de suas obras para outras línguas), enquanto Wanderley Guilherme dos

\footnotetext{
${ }^{104}$ A revista Tempo Social organizada pelo departamento foi criada somente em 1989.

${ }^{105}$ Vale aqui ressaltar que a única iniciativa nessa direção pela sociologia partiu do CERU - justamente um centro independente, embora aglutinasse vários pesquisadores da universidade - que organizou os Cadernos do CERU desde 1968.
} 
Santos, por exemplo, publicou nove e já Roberto Cardoso de Oliveira segue um pouco à frente de ambos com onze livros no mesmo período. Essa proximidade reforça a ideia, não apenas de expressivo aquecimento do mercado editorial naquele período, mas, sobretudo, de uma distância menor, em termos de hegemonia acadêmica, entre essas instituições dentro das ciências sociais brasileiras. 


\section{CONCLUSÃO}

Reconstituindo o processo de desenvolvimento das ciências sociais brasileiras ao longo dos anos de 1964-1985 a partir de dois locus centrais desse processo (os institutos de pesquisa e a universidade), essa pesquisa teve como objetivo delinear um panorama dessa fase de expansão das suas atividades. Ressalta-se, no entanto, a singularidade do processo brasileiro, pois enquanto em outros países da América Latina, tais como a Argentina, o golpe militar implicou num claro retrocesso ao processo de consolidação da sociologia (BLANCO; JACKSON, 2014, p. 65), no Brasil se deu, pelo contrário, um período de incisivo investimento do Estado na educação superior e na pesquisa científica no país com a criação de novas universidades, a ampliação das vagas nas já existentes, além da nacionalização do seu sistema de pós-graduação, o que garantiu a ampliação do curso de ciências sociais e os seus programas de pós-graduação, antes restritos a poucos nichos em São Paulo e no Rio de Janeiro.

Na Universidade de São Paulo, esse processo foi ganhando forma de maneira bastante tortuosa e acidentada. Com o afastamento de alguns pesquisadores, o corpo docente dessa instituição viu-se diante de diversas mudanças na estrutura de organização do seu curso, além da substantiva elevação no seu número de estudantes tanto na graduação como na pós-graduação. Em uma fase complicada de reestruturação (na qual se combinaram novas estruturas e antigas práticas e condicionamentos), os jovens profissionais dessa instituição encontraram grandes dificuldades em manter a liderança anteriormente estabelecida.

Aliado a esses condicionantes, o surgimento de novas iniciativas de pesquisa independentes das universidades tornou a competição ainda mais acirrada. Livres dos encargos de ensino, os institutos de pesquisa usufruíram de condições profundamente favoráveis ao seu desenvolvimento. Patrocinados pela Fundação Ford, esse novo arranjo institucional foi se afirmando em uma clara valorização à profissionalização e à autoimagem de competência acadêmica. Essa estratégia se expressou tanto nos balanços disciplinares, quanto na análise das revistas especializadas, nos quais o discurso científico moldou todo o processo de legitimação.

Através desses institutos de pesquisa e programas de pós-graduação, o período 1964-1985 acabou possibilitando a consolidação de ramos disciplinares até então dotados de pouca densidade, como é o caso da antropologia e da ciência política. Nessa 
direção, se nas décadas de "formação", a sociologia tinha papel proeminente, cabendo à ciência política e à antropologia posições secundárias na hierarquia disciplinar; nessa segunda fase o primado do olhar sociológico cederia lugar para uma configuração de maior equilíbrio entre essas três disciplinas.

Esse também foi um momento de especialização relativa em cada uma dessas áreas. Definindo novos objetos e linhas de investigação, essa geração de pesquisadores ampliou os seus horizontes de trabalho, antes ancorado nos dilemas do desenvolvimento nacional. Esse foi um movimento comum a essas três áreas disciplinares, presente não apenas nos institutos de pesquisa, mas, inclusive, nas próprias universidades do país. Não obstante, apesar de variadas, todas essas reflexões ainda trazem em comum uma forte influência da conjuntura política inaugurada com o golpe, marcada pela politização expressa nos trabalhos realizados.

$\mathrm{Na}$ verdade, a especialização mais acentuada seria um processo realizado apenas no período posterior (pós-1985) havendo maior dispersão teórica e temática no interior de cada uma das disciplinas que passam a consolidar as suas áreas de investigação de já mais distanciadas de um sentido político mais abrangente. Foi também somente depois da abertura democrática que as universidades recuperaram o domínio na pesquisa científica, retomando as suas atividades sem o peso da coerção autoritária.

Parte disso se explica pela fragilidade constitutiva dos próprios institutos que, dependendo diretamente do financiamento da Fundação Ford ou da Finep, viram os seus recursos minguarem em meados da década de 1980. Sem dispor do fluxo contínuo dos recursos reservados às universidades públicas, as instituições de pesquisa passaram por momentos de instabilidade no que se refere à manutenção das equipes de pesquisa. Assim, esses centros acabaram ou sendo incorporados à universidade ${ }^{106}$ ou passaram a depender de contratos por projeto, como é o caso do Cebrap. Ainda assim, mesmo esse instituto firmou um convênio com a Universidade de São Paulo no mesmo período, já que vários dos seus pesquisadores viriam a trilhar suas carreiras na universidade pública, onde recebiam remuneração de maneira regular.

Dispondo de maiores recursos, a universidade retorna ao centro da atividade intelectual do país, reforçando a posição dos departamentos universitários como lugar

\footnotetext{
${ }^{106}$ Esse é o caso do IUPERJ que acabou sendo incorporado pela Universidade Candido Mendes (UCAM), depois de uma grave crise financeira em 2010, na qual todos os seus professores se demitiram, sendo absorvidos pela UERJ logo depois.
} 
principal da prática nas ciências sociais e a universidade pública como eixo da carreira profissional $^{107}$. Evidentemente, a elucidação acerca das dinâmicas desse processo é uma tarefa complexa e escapa aos objetivos deste trabalho, permanecendo em aberto para pesquisas futuras. No entanto, é possível desde já sinalizar algumas das tendências concretizadas no período posterior com o objetivo de ressaltar o quanto a autonomização das ciências sociais se realizou, antes de tudo, como um longo processo que não se encerrou em 1985, embora essa seja uma fase de profunda expansão das suas atividades. Isso, porque conjurando um investimento expressivo do Estado no ensino superior e o patrocínio de agências internacionais em iniciativas de pesquisa no Brasil, as ciências sociais dispuseram de condições extremamente favoráveis para 0 desenvolvimento das suas atividades, angariando recursos para se firmarem nacionalmente dentro do cenário acadêmico brasileiro.

\footnotetext{
${ }^{107}$ Conforme afirma Sergio Miceli: “A USP voltou a reunir um grupo de professores que tinha prestígio, destaque e profissão. Foi por isso que a USP voltou (...), ela voltou nessas condições (...). Ela se beneficiou, porque ela conseguiu atrair de novo um grupo - do qual eu participei - que deu de novo prestígio e produção ao departamento. (...) Ao mesmo tempo, a USP consegue isso também, porque ela tem uma centralidade institucional, ela tem um volume de recursos que nenhuma outra universidade em outros estados tem (...). Para explicar a pujança e a recuperação, tem que levar em conta tudo isso..." Trecho da entrevista de Sergio Miceli concedida à autora em 05 de Novembro de 2013.
} 


\section{REFERÊNCIAS}

ALMEIDA, Maria Hermínia Tavares. Dilemas da institucionalização das Ciências Sociais no Rio de Janeiro. In: Sergio Miceli (Org.). A História das Ciências Sociais no Brasil. São Paulo: Sumaré/ Idesp/ Fapesp, 1989, vol. 1, pp. 118-217.

ARRUDA, Maria Arminda do Nascimento. A embalagem do sistema. A publicidade no capitalismo brasileiro. Dissertação de mestrado (Sociologia). Faculdade de Filosofia, Letras e Ciências Humanas, Universidade de São Paulo, 1975.

A modernidade possível: cientistas e ciências sociais em Minas Gerais. In: Sergio Miceli (Org.). A História das Ciências Sociais no Brasil. São Paulo: Sumaré/ Idesp/ Fapesp, 1989, vol. 1, pp. 234-315.

A sociologia no Brasil: Florestan Fernandes e a "escola paulista de sociologia". In: Sergio Miceli (Org). A História das Ciências Sociais no Brasil. São Paulo: Sumaré/ Idesp/ Fapesp, 1995, vol. 2, pp. 107-232.

2001.

Metrópole Cultura. São Paulo no meio do século XX. São Paulo: EDUSC,

AZEVEDO, Fernando de. As ciências no Brasil. São Paulo: Editora Melhoramentos, 2 vol., 1956.

BÔAS, Glaucia K. Villas. A Tradição renovada na obra de Maria Isaura Pereira de Queiroz. In: Botelho, André, Schwarcz, Lilia Moritz. (Org.). Um Enigma chamado Brasil. São Paulo: Companhia das Letras, 2009, pp. 282-295.

BORELLI, Silvia. Editora Ática: padrão de mercado, modelo de qualidade?. In: Ação, suspense, emoção: literatura e cultura de massa no Brasil. São Paulo, Educ/Fapesp, 1996.

BOSCHI, Renato Raul, CERQUEIRA, Elis Diniz. Estado e sociedade do Brasil: Uma revisão crítica. BIB. Rio de Janeiro, 1976, vol. 1, pp. 7-34.

BOURDIEU, Pierre. Algumas propriedades dos campos. In: Questões de sociologia. Rio de Janeiro: Marco Zero, 1983, pp.89-94.

O poder simbólico. Lisboa: Difel, 1989.

As regras da arte. São Paulo: Companhia das Letras, 1992.

CALDAS, Waldenyr. Acorde na Aurora. Dissertação de Mestrado (Sociologia). Faculdade de Filosofia, Letras e Ciências Humanas, Universidade de São Paulo, 1976.

CANDIDO, Antonio. A sociologia em São Paulo. In: Ensaios Paulistas. São

Paulo: Editora Anhembi S/A, 1958, pp. 510-521. 
Literatura e Sociedade. São Paulo: Companhia Editora Nacional, 1965.

2000.

A educação pela noite e outros ensaios. São Paulo: Editora Ática, $3^{\text {a }}$ edição,

A sociologia no Brasil. Revista Tempo Social, São Paulo: FFLCH-USP, 2006, $\overline{\mathrm{v} .18, \mathrm{n}^{\mathrm{o}}} 1$.

Os parceiros do rio bonito. Rio de Janeiro: Ouro sobre Azul, 2010.

CARDOSO, Fernando Henrique. Depoimento. Língua e Literatura. São Paulo: FFLCH-USP, 1981-1984, vol. 10-13, pp. 158-179.

Teoria da dependência ou análises concretas de situações de dependência?. Estudos Cebrap. São Paulo: Cebrap, 1971, vol. 1, pp. 26- 45. 2, pp. 84-118.

O Regime Político Brasileiro. Estudos Cebrap. São Paulo: Cebrap, 1972, vol.

. Estado Capitalista e o marxismo. Estudos Cebrap. São Paulo: Cebrap, 1977, vol.21, pp. 7-31.

As Eleições e o Problema Institucional: Notas sobre o Estado e a Sociedade no Brasil. Revista Dados. Rio de Janeiro: Iuperj, 1977, vol. 14, pp. 201-206.

. ; LAMOUNIER, Bolivar. A bibliografia sobre ciência política no Brasil (19491974). Revista Dados. Rio de Janeiro: Iuperj, 1978, v. 18, pp. 3-32.

CARDOSO, Irene. A Universidade da Comunhão Paulista: o projeto de criação da Universidade de São Paulo. São Paulo: Editora Cortez/ Editora Autores Associados, 1982.

Para uma crítica do presente. São Paulo: USP, Curso de Pós-Graduação em Sociologia, Ed. 34, 2001.

CASTRO, Eduardo Viveiros, SEEGER, Anthony. Pontos de vista sobre os índios brasileiros: Um ensaio bibliográfico. BIB. Rio de Janeiro: Iuperj, 1977, vol. 2, pp.3668.

CINTRA, Antonio Otávio. Sociologia e ciência. Revista Brasileira de Ciências Sociais. Minas Gerais: DCP - UFMG, 1966, vol. 4, pp. 13-34.

COHN, Gabriel. Sociologia da comunicação: Teoria e Ideologia. São Paulo: Pioneira, 1973.

CORRÊA, Mariza. A Antropologia no Brasil. In: Sergio Miceli (Org). A História das Ciências Sociais no Brasil. São Paulo: Sumaré/ Idesp/ Fapesp, 1995, vol. 2, pp. 25106.

. Revista de Antropologia: 1953-2003. Uma revista para muitas histórias. 
Revista de Antropologia da USP. São Paulo: FFLCH-USP, 2003, vol. 46, n 2, pp. 369-381.

COSTA PINTO, L.A., Carneiro. E. As ciências sociais no Brasil. Rio de Janeiro: CAPES, 1955.

CUNHA, Luiz Antonio. A universidade reformanda. São Paulo: Editora Francisco Alves, 2007.

DURHAM, Eunice; CARDOSO, Ruth . O ensino da Antropologia no Brasil. Revista de Antropologia da USP. São Paulo: FFLCH - USP, 1961, vol. 9, pp. 91-107.

. A pesquisa antropológica no Brasil. Revista de Antropologia da USP, São Paulo: FFLCH - USP, 1982, vol. 25, pp. 159-170.

A política de Pós-Graduação e as ciências sociais. BIB. São Paulo: ANPOCS, 1986, v. 21, pp. 41-55.

Depoimento. Revista de Antropologia da USP. São Paulo: FFLCH-USP, 2003, vol. 46, nº , pp. 361-363.

FAUSTO, Boris. Conflito social na República Oligárquica: A greve de 1917. Estudos Cebrap. São Paulo: Cebrap, 1974, vol.10, pp. 5-63.

FIGUEIREDO, Marcus Faria. O financiamento das Ciências Sociais. A estratégia de fomento da Fundação Ford e da Finep (1966-1985). BIB. São Paulo: ANPOCS, 1988, v. 26, pp. 38-55.

FERNANDES, Florestan. A análise sociológica das classes sociais. Revista Sociologia. São Paulo: ELSP, 1948, vol. X (2,3), pp. 91-113.

A etnologia e a sociologia no Brasil. São Paulo: Anhembi, 1958.

A sociologia no Brasil. São Paulo: Editora Vozes, 1977.

FORJAZ, Maria Cecília Spina. A emergência da ciência política no Brasil: aspectos institucionais. Revista Brasileira de Ciências Sociais, São Paulo: ANPOCS, 1997, vol. $12, \mathrm{n}^{\mathrm{o}} 35$, p. 3-15.

GARCIA, Sylvia Gemignani. Folclore e sociologia em Florestan Fernandes. Revista Tempo Social. São Paulo: FFLCH-USP, 2001, vol. 13, nº 2, p. 143-167.

$34,2002$.

Destino Í́mpar - Sobre a formação de Florestan Fernandes. São Paulo: Editora

GIANNOTTI, José Arthur. O Ardil do trabalho. Estudos Cebrap. São Paulo: Cebrap, 1973, vol. 4, pp. 5-63.

IANNI, Octávio. Estudo de comunidade e conhecimento científico. Revista de Antropologia da USP. São Paulo: FFLCH-USP, 1961, vol. 9, n², pp. 109-119. 
JACKSON, Luiz Carlos. A Tradição Esquecida: Os parceiros do rio Bonito e a sociologia de Antonio Candido. Belo Horizonte: UFMG, 2002.

. A sociologia paulista nas revistas especializadas (1940-1965). Revista Tempo Social. São Paulo: FFLCH-USP, 2004, v. 16, p. 263-283.

Tensões e disputas na sociologia paulista. Revista Brasileira de Ciências Sociais. São Paulo: ANPOCS, 2007a, v. 22, nº 65, pp. 33-49.

Gerações pioneiras na sociologia paulista (1934-1969). Revista Tempo Social. São Paulo: FFLCH-USP, 2007b, v.19, nº1, pp. 115-130.

JACKSON, Luiz Carlos; BLANCO, Alejandro. (no prelo). Sociologia no Espelho Ensaístas, cientistas sociais e críticos literários no Brasil e na Argentina (1930-1970)". São Paulo, Editora 34.

KEINERT, Fabio Cardoso. Cientistas Sociais entre a Ciência e a Política (Brasil, 1968-1985). Tese de Doutorado (Sociologia) - Faculdade de Filosofia, Letras e Ciências Humanas, Universidade de São Paulo, 2011.

LAMOUNIER, Bolívar. Formação de um pensamento autoritário na Primeira República. Uma interpretação. In: Fausto, Boris (org). História Geral da civilização Brasileira - O Brasil republicano. São Paulo: Difel, 1977, pp. 344-374.

A Ciência Política no Brasil: roteiro para um balanço crítico. In: . (Org.)

Ciência Política nos anos 80. Brasília: UNB, 1982, pp. 407-433.

LEPENIES, Wolf. As Três Culturas. São Paulo, Edusp, 1996.

LIMA, Renato Sérgio de. Catálogo de Teses e Dissertações em Sociologia: 1945-1996. Revista Plural. São Paulo: FFLCH-USP, 2007, vol. 4, n. 2, pp.1-68.

LIMA Junior, Olavo Brasil de. The Brazilian multy-party system: a case for contextual political racionality. Michigan University, mimeo, 1982.

LIMONGI, Fernando (1995). A Escola Livre de Sociologia e Política em São Paulo. In: Sergio Miceli (Org). A História das Ciências Sociais no Brasil. São Paulo: Sumaré/ Idesp/ Fapesp, 1989, vol. 1, pp. 217-233.

LUDKE, Megan. Aparecida Joly Gouveia. Recife: Fundação Joaquim Nabuco/Editora Massangana, 2010.

MAIO, Marcos Chor. Uma Polêmica Esquecida: Costa Pinto, Guerreiro Ramos e o Tema das Relações Raciais. Revista Dados. Rio de Janeiro: Iuperj, 1997, v. 40, p. $127-$ 162.

MARTINS, José de Souza. Introdução crítica à sociologia rural (org.). São Paulo: Editora Hucitec, 1981. 
MENDES, Candido. Apresentação. Revista Dados. Rio de Janeiro: Iuperj, 1966, vol. 1, pp. 3-5.

MICELI, Sergio. Por uma sociologia da sociologia. In: (Org.). A História das Ciências Sociais no Brasil. São Paulo: Sumaré/ Idesp/ Fapesp, 1989a, vol. 1, pp. 72110.

(1989b). Condicionantes do desenvolvimento das Ciências Sociais. In:

(Org.). A História das Ciências Sociais no Brasil. São Paulo: Sumaré/ Idesp/ Fapesp, 1989b, vol. 1, pp. 72-110.

A desilusão americana. Relações acadêmicas entre Brasil e Estados Unidos. São Paulo: Sumaré/Idesp, 1990.

(Org.) A Fundação Ford no Brasil. São Paulo: Editora Sumaré, 1993.

(1995). A Fundação Ford e as cientistas sociais no Brasil, 1962-1992. In: (Org.). A História das Ciências Sociais no Brasil. São Paulo: Sumaré/ Idesp/ Fapesp, 1995, vol. 2, pp. 341-396.

Intelectuais à brasileira. São Paulo: Companhia das Letras, 2001.

MIRANDA, Orlando Pinto. Tio Patinhas e os Mitos da Comunicação. Dissertação de Mestrado (Sociologia). Faculdade de Filosofia, Letras e Ciências Humanas, Universidade de São Paulo, 1975.

NEVES, Clarissa Eckert Baeta. Estudos sociológicos sobre a educação no Brasil. In: Miceli, Sergio (Org.). O que ler na ciência social brasileira 1970-2002. São Paulo: Editora Sumaré; CAPES, 2002, v. IV, p. 351-437.

NOGUEIRA, Oracy. Os estudos de comunidade no Brasil. Revista Sociologia. São Paulo: ELSP, 1995, vol. 3, nº 2.

OLIVEIRA, Francisco de. O terciário e a divisão social do trabalho. Estudos Cebrap. São Paulo: Cebrap, 1979, vol. 24, pp. 138-168.

OLIVEIRA, Lucia Lippi. A sociologia de Guerreiro Ramos. Rio de Janeiro: Editora UFRJ, 1995.

OLIVEIRA, Roberto Cardoso. O contacto interétnico e o estudo das populações. Revista de Antropologia da USP. São Paulo: FFLCH-USP, 1969, vol. 17-20, pp. 3148 .

. Sobre o pensamento antropológico. Rio de Janeiro: Tempo Brasileiro, 1988.

O Movimento dos conceitos na Antropologia. Revista de Antropologia da USP. São Paulo: FFLCH-USP, 1993, vol. 36, pp. 13-31.

ORTIZ, Renato. Notas sobre as ciências sociais no Brasil. Novos Estudos CEBRAP. São Paulo: Cebrap, 1990, n²7, pp. 157-162. 
PONTES, Heloísa. Destinos mistos: o grupo cultural Clima no sistema cultural paulista (1940-1968). São Paulo: Companhia das Letras, 1998.

PÉCAULT, Daniel. Os Intelectuais e a política no Brasil: entre o povo e a nação. São Paulo, Editora Ática, 1990.

PEIXOTO [MASSI], Fernanda. Franceses e norte-americanos nas ciências sociais brasileiras (1930-1960). In: Sergio Miceli (Org). A História das Ciências Sociais no Brasil. São Paulo, Sumaré/ Idesp/ Fapesp, 1989, vol. 1, pp. 72-110.

Diálogos Brasileiros: uma análise da obra de Roger Bastide. São Paulo, EDUSP/FAPESP, 2000.

; Simões, Julio A. A Revista de Antropologia e as ciências sociais em São Paulo: Notas sobre uma cena e alguns debates. Revista de Antropologia da USP. São Paulo: FFLCH-USP, 2003, vol. 47, nº 2; pp. 383-409.

PEREIRA, João Baptista Borges. Lembrando Egon Schaden. Revista do Instituto de Estudos Brasileiros. São Paulo: IEB-USP, 2003, vol. 33, pp. 9-12.

PULICI, Carolina. Entre sociólogos: versões conflitivas da "condição de sociólogo" na USP dos anos 1950-1960. São Paulo: Edusp, 2004.

QUEIROZ, Maria Isaura Pereira. Desenvolvimento no Brasil das pesquisas empíricas de sociologia: ontem e hoje. Ciência e Cultura. São Paulo: SBPC, 1972, pp. 511-525.

- Desenvolvimento das ciências sociais no Brasil: Nascimento e expansão. Ciência \& Trópico. Recife: Fundação Joaquim Nabuco, 1992, v. 20, nº 2, pp. 387-412.

CERU faz trinta anos: primeiros passos. Cadernos CERU. São Paulo: FFLCH-USP, n. 6, pp. 11-31.

QUEIROZ Jr., Teófilo Filho. Preconceito de cor e a mulata na literatura brasileira. Dissertação de Mestrado (Sociologia). Faculdade de Filosofia, Letras e Ciências Humanas, Universidade de São Paulo, 1975.

RAMOS, Guerreiro. Introdução crítica à sociologia brasileira. Rio de Janeiro: Andes, 1957.

RINGER, Fritz. El campo intelectual, la historia intelectual y la sociologia del conocimiento. Revista Prismas. Argentina, 2004, nº 8, pp. 99-118.

REIS, Elisa. A construção intelectual e a política das ciências sociais brasileiras: a experiência do Iuperj. In: Miceli, S. (org.) A Fundação Ford no Brasil. São Paulo: Sumaré/Fapesp, 1993, pp. 115-130.

REIS, Fábio Wanderley. A propósito de ciência e dialética. Revista Brasileira de Ciências Sociais. Minas Gerais: UFMG, 1966, vol. 4, 1, pp. 31-67. 
As Eleições e o Problema Institucional: A Revolução é a Geral Cooptação. Revista Dados. Rio de Janeiro: Iuperj, 1977, vol. 14, pp. 185-200.

A delimitação do 'político' nos trabalhos sobre partidos, eleições e crise institucional. In: SOARES, Ricardo Prata et alli (Org). Estado, participação política e democracia. Brasília: CNPq/Anpocs, 1985, pp.115-145.

- Minas e as ciências sociais: Evocações e algumas polêmicas. Teoria e Sociedade. Belo Horizonte: UFMG, número especial: Imagens de Minas - Homenagem a Fernando Correia Dias, 2004, pp. 15-31.

ROCHA, Maria Eduarda da Mota. Em busca de um ponto cego: notas sobre a sociologia da cultura no Brasil e a diluição da mídia como objeto sociológico. Revista Sociedade e Estado. Brasília: UNB, 2011, vol. 26, n. 3, pp. 453-469.

RUBIM, Christina de Rezende. Antropólogos brasileiros e a antropologia no Brasil: A era da pós-graduação. Tese de doutorado (Antropologia Social). Instituto de Filosofia, Letras e Ciências Humanas, Universidade de Campinas, 1996.

SALLUM, Jr. Brasílio. Notas sobre a gênese da Sociologia Política em São Paulo. Política e Sociedade. Florianópolis: UFSC, 2002, v. 1, n. 1, pp. 73-86.

SANTOS, Wanderley Guilherme. A imaginação político-social brasileira. Revista Dados. Rio de Janeiro: Iuperj, 1967, v.3, pp. 133-149.

. Raízes da imaginação política brasileira. Revista Dados. Rio de Janeiro: Iuperj, 1970, v. 7, pp. 137-161. 1978.

Ordem burguesa e liberalismo no Brasil. São Paulo: Livraria Duas Cidades,

The calculus of conflict: impasse in Brazilian politics and the crisis of 1964. (PhD Dissertation). Stanford University, 1979.

A Ciência Política na América Latina. Revista Dados. Rio de Janeiro: Iuperj, 1980, v. 23, pp. 15-27.

SCHWARTZMAN, Simon. Desenvolvimento e Abertura Política. Revista Dados. Rio de Janeiro: Iuperj, 1969, vol. 6, pp. 24-56.

As Eleições e o Problema Institucional: Estado e a Sociedade no Brasil. Revista Dados. Rio de Janeiro: Iuperj, 1977, vol. 14, pp. 164-184.

Formação da comunidade científica no Brasil. Rio de Janeiro, $\overline{\text { Finep/Companhia Editora Nacional, } 1979 .}$

SILVA, Dimitri Pinheiro da. Da política à ciência política, da ciência política à política: a trajetória acadêmica de Paula Beiguelman (1949-1969). Dissertação de mestrado (Sociologia) - Faculdade de Filosofia, Letras e Ciências Humanas, 
Universidade de São Paulo, 2009.

SORJ, Bila. Demarcando o campo da sociologia: a contribuição de Costa Pinto. In: Marcos Chor Maio; Glaucia Villas Bôas. (Org.). Ideias de modernidade e sociologia no Brasil. Ensaios sobre Luiz de Aguiar Costa Pinto. Porto Alegre: Editora da Universidade, 1999, v. 1, p. 223-228.

SOUZA, Amaury de. The nature of corporatist representation: leaders and members of organized labor in Brazil. Boston: MIT, mimeo, 1976.

TASCHNER, Gilesa Goldenstein. Do jornalismo político à indústria cultural. Dissertação de mestrado (Sociologia) - Faculdade de Filosofia, Letras e Ciências Humanas, Universidade de São Paulo, 1978.

TOLEDO, Caio Navarro de. ISEB: fábrica de ideologias. São Paulo: Editora Ática, 1977.

UNIVERSIDADE DE SÃO PAULO. Anuário da Faculdade de Filosofia Letras e Ciências Humanas (1964). São Paulo, 1965. Paulo, 1971.

.Anuário da Faculdade de Filosofia Letras e Ciências Humanas (1970). São

. Anuário da Faculdade de Filosofia Letras e Ciências Humanas (19711972). São Paulo, 1973.

Anuário da Faculdade de Filosofia Letras e Ciências Humanas (19731974). São Paulo, 1975.

Anuário da Faculdade de Filosofia Letras e Ciências Humanas (19751976). São Paulo, 1977.

Anuário da Faculdade de Filosofia Letras e Ciências Humanas (19771978). São Paulo, 1979.

Anuário da Faculdade de Filosofia Letras e Ciências Humanas (19791980). São Paulo, 1981.

VEIGA, Laura da. A trajetória de uma geração de cientistas sociais em Belo Horizonte: imagens de anos nem sempre dourados. $3{ }^{\circ}$ Congresso Nacional de Sociologia. Brasília: Julho, 1987.

VELHO, Otávio Guilherme. Antropologia para sueco ver. Revista Dados. Rio de Janeiro: Iuperj, 1980, vol. 23, nº 1, pp. 79-91.

VENÂNCIO, Giselle Martins; FURTADO, André Carlos. Brasiliana \& História Geral da Civilização Brasileira: escrita da história, disputas editoriais e processos de especialização acadêmica (1956-1972). Revista Tempo e Argumento. Florianópolis: UFSC, 2003, v. 5, n.9, pp. 05 - 23. 
WAGLY, Charles Estudos de comunidade no Brasil sob perspectiva nacional. Revista Sociologia. São Paulo: ELSP, 1954, vol. 16, pp. 3-22.

WEFFORT, Francisco. Nota Sobre a Teoria da Dependência: Teoria de Classe ou Ideologia Nacional. Estudos Cebrap. São Paulo: Cebrap, 1971, vol. 1, pp. 1-24.

Origens do sindicalismo populista no Brasil (A conjuntura do após-guerra). Estudos Cebrap. São Paulo: Cebrap, 1973, vol. 4, pp. 66-105.

WITTER, José Sebastião. USP 50 anos - Registros de um debate. São Paulo: Edusp, 2006.

Entrevistas publicadas

ARRUDA, Maria Arminda do Nascimento. (2006). Entrevista concedia à BASTOS, Elide et alli. In: Elide Rugai Bastos; Fernando Abrucio; Maria Rita Loureiro ; José Marcio Rego. (Org.). Conversas com Sociólogos Brasileiros. São Paulo: Editora 34, p. 353-374.

CARDOSO, Fernando Henrique. (2009) Entrevista concedida à Limongi, Fernando et alli. In: Moura, F; Montero, P. (orgs.) Retrato do grupo: 40 anos do Cebrap. São Paulo, Cosacnaify.

CARDOSO, Irene (2010). "Entrevista com Irene Cardoso". Entrevista concedida à JACKSON, Luiz; KEINERT, Fabio Cardoso; BLANCO, Alejandro. In: Revista Tempo Social. São Paulo: USP, vol. 22, n. 2, pp. 265-285.

CARDOSO, Ruth. (1998). "Entrevista com Ruth Cardoso". Entrevista concedida à FAR, Alessandra El et alli. In: Cadernos de Campo. São Paulo: USP, vol. 7, pp. 149-166.

COHN, Gabriel. (2006). Entrevista concedia à BASTOS, Elide et alli. In: Elide Rugai Bastos; Fernando Abrucio; Maria Rita Loureiro ; José Marcio Rego. (Org.). Conversas com Sociólogos Brasileiros. São Paulo: Editora 34, p. 219-250.

FAUSTO, Bóris (1988). “Organizando a História Geral da Civilização Brasileira”. In: Estudos Históricos. Rio de Janeiro: vol. 1, ${ }^{\circ}{ }^{\circ} 1$, pp. 162-166.

GIANNOTTI, José Arthur (2009). Entrevista concedia à NOBRE, Marcos et alli. In: Moura, F. \& Montero, P. (orgs.) Retrato do grupo: 40 anos do Cebrap. São Paulo: Cosacnaify.

KOWARICK, Lucio (2009). Entrevista concedida a LAVALLE, Adrian et alli. In: Moura, F. \& Montero, P. (orgs.) Retrato do grupo: 40 anos do Cebrap. São Paulo: Cosacnaify.

MICELI, Sergio. (2006). Entrevista concedia à BASTOS, Elide et alli. In: Elide Rugai Bastos; Fernando Abrucio; Maria Rita Loureiro ; José Marcio Rego. (Org.). Conversas com Sociólogos Brasileiros. São Paulo: Editora 34, p. 353-374. 
PEREIRA, João Baptista Borges (2003). "Pessoa e Instituição - Entrevista com J. B. Borges Pereira" (Outubro de 2003). Revista de Antropologia da USP. São Paulo: USP, vol. 46, n 2, pp. 319-341.

SALLUM, Jr., Brasilio (2005). “Algumas notas sobre a formação em Ciências Sociais. (Entrevista com o professor Brasilio Sallum Junior)". Entrevista concedida à Revista Plural. Revista Plural, São Paulo: USP, v. 12, p. 134-148.

. (2006). Entrevista concedia à BASTOS, Elide et alli. In: Elide Rugai Bastos; Fernando Abrucio; Maria Rita Loureiro ; José Marcio Rego. (Org.). Conversas com Sociólogos Brasileiros. São Paulo: Editora 34, p. 269-290.

OLIVEIRA, Francisco de. (2009) Entrevista concedida a BARBOSA, Alexandre et alli. In: Moura, F; Montero, P. (orgs.) Retrato do grupo: 40 anos do Cebrap. São Paulo, Cosacnaify.

OLIVEIRA, Roberto Cardoso (1993). Entrevista concedida a FAUSTO, Carlos; LEITE, Yonne; COSTA, Vera da Rita; WEINGRILL, Carmen. Informações disponíveis em: http://www.canalciencia.ibict.br/notaveis/livros/roberto_cardoso_de_oliveira_39.html. Acesso em 01 de Abril de 2014.

Entrevista à pesquisadora

AUGUSTO, Maria Helena O.. São Paulo, 24 de Janeiro de 2014.

BLAY, Eva. São Paulo, 04 de Fevereiro de 2014.

CARDOSO, Irene. São Paulo, 14 de Fevereiro de 2014.

MARTINS, Heloísa Helena Teixeira. São Paulo, 15 de Janeiro de 2014.

MICELI, Sergio. São Paulo, 05 de Novembro de 2013.

\section{Documentos eletrônicos}

Associação Brasileira de Antropologia. Informações disponíveis em: http://www.portal.abant.org.br/index.php/institucional/features. Acesso em $15 \mathrm{de}$ Janeiro de 2014. 